This dissertation has been

microfilmed exactly as received

$69-4859$

COLE, Donald Preston, 1937-

THE DEMAND FOR DENOMINATIONS OF U.S. CURRENCY, 1914-65.

The Ohio State University, Ph.D., 1968

Economics, theory

University Microfilms, Inc., Ann Arbor, Michigan

i) COPYRIGHT BY

DONALD PRESTON COLE

1969 


\section{THE DEMAND FOR DENOMINATIONS}

OF U.S. CURRENCY, 1914-65

\section{DISSERTATION}

\section{Presented in Partial Fulfillment of the Requirements for the} Degree Doctor of Philosophy in the Graduate School of

The Ohio State University

By

Donald Preston Cole, A.B., M.A.

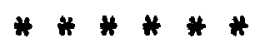

The Ohio State University

1968

Approved by

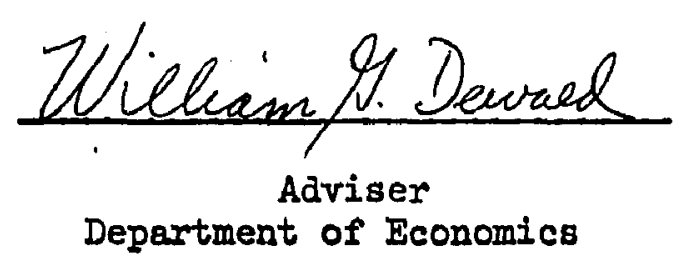




\section{ACKNOWLEDGMENTS}

The author owes a debt of gratitude to Professor William G. Dewald who first suggested this project and subsequently guided it with exact and painstaking care. Special recognition must also be given to Professors Frances Quantius and David McCalmont whose scholarly criticisms helped to clarify and eliminate potential ambiguities in the analysis. A word of appreciation must also go to Miss Anita Harwick for her assistance in programing the statistical work and to Mrs. Nanette Lemmerman for typing the final manuscript. The author accepts full responsibility for any errors or ambiguities that may remajin in the following pages.

Donald P. Cole 
VITA

December 1, 1937

1959 . : . .

$1959-1961$. . .

1961 . . . .

1962 . . . .

1964 . . . .

$1966-1968$. . .
$1962-1963$. .

$1963-1966$. .

Born - Kearny, New Jersey

A.B., Drew University, Madison, New Jersey

Graduate Assistant, Department of Economics, University of Montana, Missoula, Montana

M.A., University of Montana, Missoula, Montana

Economic Analyst, Bankers Trust Company, New York City

Instructor, Department of Economics, Upsala College, East Orange, New Jersey

Assistant Instructor, Department of Economics, The Ohio State University, Columbus, Ohio

Economic Consultant, Select Committee on Government Research, U.S. House of Representatives, Washington, D.C.

Instructor, Department of Economics,

Drew University, Madison, New Jersey

\section{PUBLICATIONS}

"The Impact of Federal Research and Development Programs," A Report of the Select Committee on Government Research, U.S. House of Representatives, Eighty-Eighth Congress, 1964

FIELDS OF STUDY

Major Field: Economics

Studies in Economic Theory. Professors Clifford James and Richard Tybout

S̄tudies in Monetary Economics. Professors William G. Dewald and Frances Quantius

Studies in Public Finance. Professor Arthur Iynn

Studies in Economic Planning. Professor Meno Lovenstein 
TABLE OF CONTENTS

Page

ACKNOWLEDGMENTS. • • • • • • • • • •

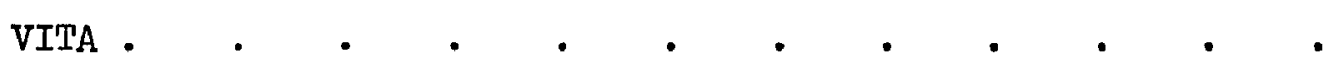

LIST OF TABLES • • • • • • • • • • • •

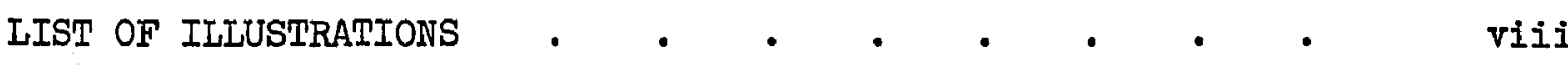

INTRODUCTION

Chapter

I. THEORETICAL FRAMEWORK. • • • • •

Denominational Demands and Differential

Transactions Costs

Variables Affecting the Distribution of Denominations

Summary of Expected Relationships

II. SECULAR VARIATION IN DENOMINATIONAL DEMANDS,

. 1914-65 .

Summary of Secular Movements in the Average Denomination

Behavior of the Distribution of Denominations During Five Subperiods, 1914-65

III. ESTIMATION OF SECULAR DEMAND FUNCTIONS FOR CURRENCY DENOMINATIONS, $1923-65$. $. \quad . \quad . \quad$ •

Measurement of the Variables Interpretation of Results Using Annual Data, 1923-65

Denominational Demands and Lagged Responses

IV. SEASONAL VARIATION IN THE DISTRIBUTION OF CURRENCY DENOMINATIONS, $1948-65$. $\quad$. . .

Seasonal Patterns in the Average Denomination Individual Denominations and "Seasonality" 
TABLE OF CONTENTS (continued)

\begin{tabular}{|c|c|c|c|c|c|c|c|c|c|c|}
\hline CON & CLUSIONS & • & - & - & • & - & - & - & • & 122 \\
\hline APPENDIXES & - & - & - & - & - & • & - & • & - & 129 \\
\hline BIBLIOGRAPHY & - & - & • & - & - & - & . & • & - & 149 \\
\hline
\end{tabular}




\section{LIST OF TABLES}

Table

1. Value of an Average Unit of Paper Currency in Circulation in the United States, 1914-65 . .

2. Distribution Ratios of Currency Denominations in the United States, 1914-32 . . . .

3. Distribution Ratios of Currency Denominations in the United States, $1933-65$. . . .

4. Selected Components of National Wealth in the United States, 1912-55.

5. Comparison of Normalized Values of the Average Denomination and the Consumer Price Index.

6. Estimates of the Demand for Denominations of Currency Using Levels of the Data, 1923-65 .

7. Matrix of Simple Correlation Coefficients Between Seven Explanatory Variables . . . .

8. Demand Estimates for Denominations Using First Difference Data, 1923-65 . . . .

9. Demand Estimates for Denominations Using Both First Differences and Levels of the Data, 2923-65

10. Factors Affecting the Average Denomination of Currency, 1923-65..$\quad$. . .

11. Estimates of Lagged Responses in the Demand for Denominations of Currency, 1923-65

12. Estimates of the Demand for Denominations of Currency, May, 1933-December, 1965 


\section{LIST OF TABLES (continued)}

Table

Page

13. Estimates of Seasonal Coefficients for Selected Currency Denominations, 1948-65 . . . .

14. Value of Denominational Holdings by Monetary Authorities a.s a Percentage of Total Paper Currency Outstanding, 1931, 1945-48 . . .

15. Net Production and Inventories of Currency Denominations in Relation to Changes in Amounts in Circulation, June 30, 1949-June 30, 1965

16. Availability of Statistics on Currency Denominations for Selected Countries. 
LIST OF ILIUSTRATIONS

Figure

Page

1. Value of an Average Unit of Paper Currency in Circulation in the United States, 1914-65.

2. Distribution Ratios for $\$ 1, \$ 5, \$ 10, \$ 20, \$ 50$ and $\$ 100$ Denominations, 1914-65 . . . . .

3. Distribution Ratios for Coin, $\$ 2, \$ 500$ and $\$ 1000$ Denominations, $1914-65$. . . . . .

4. Seasonal Coefficients for the Average Denomination of Paper Currency, January, 1948-December, 1965 .

5. Seasonal Coefficients for Small Currency

Denominations, January, 1948-December, 1965. .

6. Seasonal Coefficients for Large Currency

Denominations, January, 1948-December, 1965. .

108 


\section{INTRODUCTION}

Although the services provided by currency closely parallel those provided by demand deposits, the substitutability between these two assets is imperfect, a point which will encourage the use of one rather than another in any given transaction. For certain transactions (e.g., the purchase of low priced retail items) currency may be the best asset for an individual to hold, while for others (e.g., making the down payment on a house) demand deposit money may be preferable. The fact that these two assets are not perfectly substitutable for any transaction is explained by the differential transactions costs ${ }^{l}$ asscciated with the acquisition and expenditure of these assets. Presumably, individuals. wishing to make a transaction in money will compare the costs associated with the two assets and will select that asset whose transactions cost is lowest.

lThe term "transaction" refers to the exchange of a monetary asset for other assets. The "transactions cost" of a transaction with a monetary asset equals the sum of all costs associated with the acquisition and expenditure of this asset. Someone wishing to make a transaction in currency, for example, must expend effort in locating places where currency might be obtained and later exchanged for other assets. If the individual obtains currency by converting other financial assets into currency, he incurs additional costs (as, for example, brokerage fees and transfer taxes in the sale of securities, and service charges in the cashing of checks).

These costs should be distinguished from those which arise over the interim between the receipt and expenditure of currency ("storage costs"). In the latter category one would find the costs of maintaining storage facilities (e.g., wallets and safe deposit boxes), the nuisance involved in counting out bills for storage, the risk of losing the currency through theft or other misfortune, the income foregone through

s holding currency rather than interest-earning assets, etc. Since both transactions and storage costs involve many subjective considerations (e.g., individual valuations of effort expended and risk incurred), they are not easily quantified. However, as will be shown later, it is possible to measure these costs indirectly through observing the relative amounts of various assets held. 
As an empirical matter, it is extremely difficult to distinguish units of money according as they are said to be held for one or another purpose: ${ }^{2}$ Although a demand deposit may be better suited to the purchase of a home than currency, it can also be held for countless other reasons. As far as deposit money is concerned, it does not seem possible that particular units of money can be associated with particular transactions. ${ }^{3}$ Currency $^{4}$ is a somewhat different matter. The fact that the currency stock is denominated in certain discrete units raises the possibility that particular denominations of currency might perform particular services in the payments process. We generally associate particular coins with particular payments: pennies with gum machines, dimes with pay phones, quarters with washing machines, etc. Small denominations of U.S. paper currency ${ }^{5}$ (i.e., \$I, \$2, \$5, \$10 and \$20 bills) are generally used for smaller retail transactions, while large

2The possibiz:-ty that money holdings can be quantified according to the Keynesian "active-idle balances" distinction is examined in the work of Tobin, and Bronfenbrenner and Mayer. (See James Tobin, "Iiquidity Preference and Monetary Policy," Review of Economic Statistics, XXIX, [May, 1947], pp. 124-31; also M. Bronfenbrenner and T. Mayer, "Liquidity Functions in the American Economy," Econometrica, XXVIII, [October, 1960], pp. 810-34).

${ }^{3}$ Even if it were possible to distinguish a unit of deposit money as to the purpose for which it was held, the problem is complicated by the possibility that a close substitutability may exist between the money supply as a means of payment and as an alternative to other repositories of wealth. See, for example, A.H. Meltzer, "The Demand for Money: The Evidence from Time Series," Journal of Politicel Economy, LXXI, (June, 1963), p. 224.

"The term "currency" is used in the present study to embrace both paper currency and coin.

5 The present study distinguishes units of currency by denomination rather than by kind. Traditionally, the term "U.S. currency" refers only to currency issued by the U.S. Treasury. In this study the term refers to total currency (i.e., the issues of both the Treasury and the Federal Reserve). 
denominations (i.e., $\$ 50, \$ 100, \$ 500, \$ 1,000, \$ 5,000$ and $\$ 10,000$ bills) are usually employed in making larger valued purchases or are stored against infrequent purchases. ${ }^{6}$ Denominations of currency may therefore be regarded as close, but imperfect substitutes for one another. The imperfect substitutability between any two denominations results from the fact that different denominations involve slightly different transactions costs and yield slightly different services. ${ }^{7}$ This point lies at the heart of the matter of the demand for denominations of currency. The distribution of currency denominations is not an important statistic in its own right, but it may be significant as a reflection of economic behavior patterns that are vital. What we propose to do is to examine the relationship between relative holdings of various U.S. currency denominations and factors that can be expected to affect the demand for money more generally. In Chapter I the theoretical basis for these relationships is established. Chapter II examines the historical evidence on changes in the distribution of denominations of U.S. currency over the period 1914-65. Then, in Chapters III and IV

6Designating "small" denominations as those of $\$ 20$ or less and "large" denominations as those of $\$ 50$ or more follows a breakdown used by both the U.S. Treasury and the Federal Reserve. The very smallest denominations (i.e., units of coin in the amounts of one cent, five cents, etc.) are intentionally omitted from this study. Information on separate coin denominations is not available.

7 This is analogous to the imperfect substitutability in general between financial assets. (See Edgar Feige, The Demand for Liquid Assets: A Temporal Cross-Section Analysis [Englewood Cliffs, N.J.: Prentice-Hall, 1964]), pp. 16-42. 
regression estimates of the demand for currency denominations ${ }^{8}$ are developed to test for secular and seasonal influences. Our tentative conclusions might be summarized as follows:

(1) The historical evidence on the distribution of denominations of U.S. currency from 1914 to 1965 suggests that a rise in the demand for currency for use in current transactions (relative to the total demand for currency) is accompanied by increased relative preferences for small denominations, while a fall in the demand for currency for current transactions (relative to the total demand for currency) is accompanied by increased relative demands for large denominations.

(2) With regard to broad secular changes in the distribution of denominations, the rise in the demand for currency for use in current transactions (relative to the total demand for currency) tended to occur only during those periods which were free of major wars or depressions (i.e., 1919-29 and 1948-65). During other periods between 1914 and 1965 the tendency was for a fall in the demand for currency for use in current transactions (relative to the total demand for currency).

(3) Evidence on seasonal variation in the distribution of currency denominations (for the period 1948-65) suggests that seasonal influences are quite strong. During those months when the volume of retail activity is high we observe a rise in the demand for

8The "demand for currency denominations" corresponds to the dollar volume of total currency (by denomination) actually in circulation. It includes (1) all holdings by households and business firms; (2) all bank vault cash; and (3) total currency lost, destroyed or carried abroad. It excludes currency held' by the Federal Reserve, U.S. Treasury, and mints and assay offices. 
currency for use in current transactions (relative to the total demand for currency). But when retail activity is at a low level, current transactions needs for currency show a relative decline. Before examining the historical evidence on the distribution of denominations it is necessary that attention be directed to several of the more important theoretical issues in the subject of denominational demands. This is done in the following chapter. 


\section{CHAPTER I}

\section{Theoretical Framework}

\section{(A) Denominational Demands and Differential Transactions Costs}

By holding currency an individual gains command over a variety of possible consumption (and production) activities. One's holdings of this asset will depend upon his expectations of the size and timing of payments. Certain transactions patterns (particularly those involving the purchase of retail items) may require this individual to pay out currency in small amounts over frequent intervals, while others may involve large expenaitures over infrequent intervals. Some transactions patterns may not involve the payment of currency at all in the current period, thereby presenting this individual with the opportunity to invest temporarily idle currency at interest and to withdraw these funds as needed at a later date. ${ }^{1}$

1This possibility is generally examined with respect to total money holdings, rather than currency alone. See, for example, W.J. Baumol, "The Transactions Demand for Cash: An Inventory Theoretic Approach," Quarterly Journal of Economics, IXVI, (1952), pp. 545-56; also, James Tobin, "The Interest Elasticity of Transactions Demand for Cash," Review of Economics and Statistics, XXXVIII, (1956), pp. 241-47.

An additional possibility is that the funds might be "hoarded". By this we mean the practice of letting funds received in the current period lie idle until some future period. "Currency hoards" are those accumulated stocks of currency resulting from past hoarding. 
By tailoring their holdings of currency to the expected pattern of payments, individuals and business firms are able to reduce the real costs of having to obtain currency at the time their payments come due. This applies not only to the amount of currency held, but also to the denominational distribution of these holdings. Expectations of frequent, lower-valued payments will probably lead individuals and business firms to increase their relative holdings of small bills. Should they fail to do so, they will have to bear the cost of converting unwanted denominations into desired denominations at the time payments come due. The same sort of costs are incurred by those holding small bills when payments are expected to be infrequent and/or to involve higher-valued purchases.

A few examples can be used to illustrate this point. Assume that a manufacturing firm has produced a large number of items, each of which it intends to sell for cash at a price of $\$ 20$. All production costs have been met, so that the sale of these items immediately results in an increase in the firm's currency assets (initially valued at $\$ 100,000$ ). No other financial assets (e.g., demand deposit accounts) are available for the operation of the business. Furthermore, let us make the greatly simplified assumption that the stock of currency assets can be held in only one of two forms: (I) a "bundle" of small denominations (none of which can have a value in excess of $\$ 20$ ), or (2) a "bundle" of large denominations (consisting of bills valued at between $\$ 50$ and $\$ 10,000$ ). Which of these alternative forms of holding currency will be chosen? The answer depends, of course, upon the firm's expectations of the size and timing of payments for its product. If in the current period 
it expects to sell a large number of its goods to many different buyers, the firm will stock small bills in order to meet the demands of customers at the time the sales are made. Each time an item is sold total cash assets increase by $\$ 20$. In some cases customers might not have bills which are small enough to make the purchase. The firm would then have to draw "change" from its currency portfolio; without recourse to a portfolio of small bills the firm would not be able to make the sale. Having to postpone the sale until the proper denominations are obtained elsewhere (either from other customers or businesses) might jeopardize the firm's relations with the buyer.

Suppose, however, that the firm expects that purchases of its product will be infrequent during the current period and/or that they will be made in volume by only a handful of buyers. In this case the need for small denominations is substantially reduced. Indeed, the firm may rely exclusively on current sales as a means for obtaining these bills, rather than on a currency portfolio which consists entirely of the smaller denominations. Given the storage costs of maintaining such a portfolio, such a response is not unreasonable.

Currency storage costs are inversely related to the size of the denominations held. The firm wishing to store a fixed sum of wealth in currency can reduce the costs of storage (e.g., the costs of maintaining safety deposit boxes, the nuisance involved in counting out many bills for storage, etc.) by using large denominations instead of small ones. Using our earlier example, the total costs to the enterprise of storing $\$ 100,000$ in large bills are much less than the costs of storing the same 
amount in small bills. This could be important for a business (e.g., a bank) which held millions of dollars in cash, part to meet regular withorawals, and part as emergency reserves. ${ }^{2}$

The above examples greatly oversimplify the differential costs involved in the acquisition, storing and expenditure of different currency denominations. We will have occasion to examine these costs in greater detail in Section (B). Brief reference should be made at this point, however, to one type of cost which may have great relevance to the distribution of denominations, the costs of surrepticious transactions. By requesting payment in currency or transferring other forms of wealth into currency, certain business firms and individuals can conceal their transactions. Presumably, they would do so only if the disclosure of the transaction would involve some cost to them. Examples of such transactions would be purchases in black markets and tax evasion. The risks of disclosure might be minimized in such cases through the use of large denominations, which permit people to store a great deal of wealth in a small and (hopefully) inconspicuous place. Assume, for example, that the income of the business firm referred to earlier is not subject to withholding or the usual sort of reporting (i.e., that it is an unincorporated

${ }^{2}$ Since they do not have access to Federal Reserve currency exchange facilities, non-member banks may find it useful to maintain an emergency balance of currency during financial crises. The largest part of this balance would probably consist of bills valued in the intermediate (e.8., $\$ 10, \$ 20$, and $\$ 50$ ) range, since these bills can be conveniently $\therefore \quad$ used for the purpose of making payments to customers and (unlike those in the lower-valued range) involve less nuisance cost when they are counted out for storage. In addition, some small part of this emergency balance may consist of very large bilis (e.g., $\$ 5,000$ and $\$ 10,000)$ which might be shown to customers as "proof" of bank solvency in times of general financial crisis. 
enterprise). Assume further that it has the opportunity to sell its entire inventory of goods to a single individual. By demanding payment in currency the firm can escape the tax on its income. Moreover, it might be able to reduce the risks of disclosure by requiring that payment be made in a few very large bills, which subsequently might be easily hidden from the tax authorities. ${ }^{3}$ similar reasoning could be applied if this firm were selling its goods in black markets, where the value of the average transaction is presumably quite high and the risks of disclosure are generally great.

Obviously, firms and individuals are able to choose among a much wider variety of denominations than the above examples allow for; currency portfolios generally consist of some combination of both large and small bills. The important point is that holdings of particular denominations are ultimately dependent upon the expected pattern of transactions.

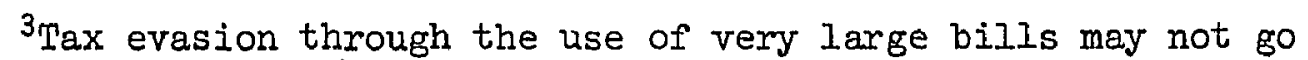
completely unnoticed; however. Since 1945 the U.S. Treasury has required banks to report transactions which involve substantial amounts of currency or large bills. At the present time banks are required to report: (1) transactions involving $\$ 2,500$ or more of U.S. currency in denominations of $\$ 100$ or higher; (2) transactions involving $\$ 10,000$ or more of U.S. currency in any denomination; and (3) transactions in any denomination which bank officials feel is "not commensurate with the customary conduct of the business, industry or profession of the person or organization concerned."

Thus there is reason to believe that attempts at evading taxes through the use of the largest bills may prove unsuccessful, but only under certain circumstances. Tax evaders can escape the effect of the regulations through requesting several currency payments (rather than a single payment) from persons who owe them money, the effect of which might be to reduce the size of "non-customary" withdrawals from banks. Bank "* officials may not be aware of the regulations or, if they are, may not enforce them. Even if all banks did comply with them, individuals and businesses may still successfully evade taxes through requesting payment in $\$ 50$ bills, since these are not explicitly encompassed in the regulations. 
Individuals and business firms will substitute one group of denominations for another when the costs of such transactions are unequal at the margin.

(B) Variables Affecting the Distribution of Denominations

In this section we will explore the variables upon which the demand for currency denominations depends. These variables will then be incorporated into least squares estimates of denominational demand functions in Chapter III. These estimates employ the "average denomination of currency" as the dependent variable. At this point it will be useful to examine the meaning of the average denomination.

Formaliy, the average denomination is represented by:

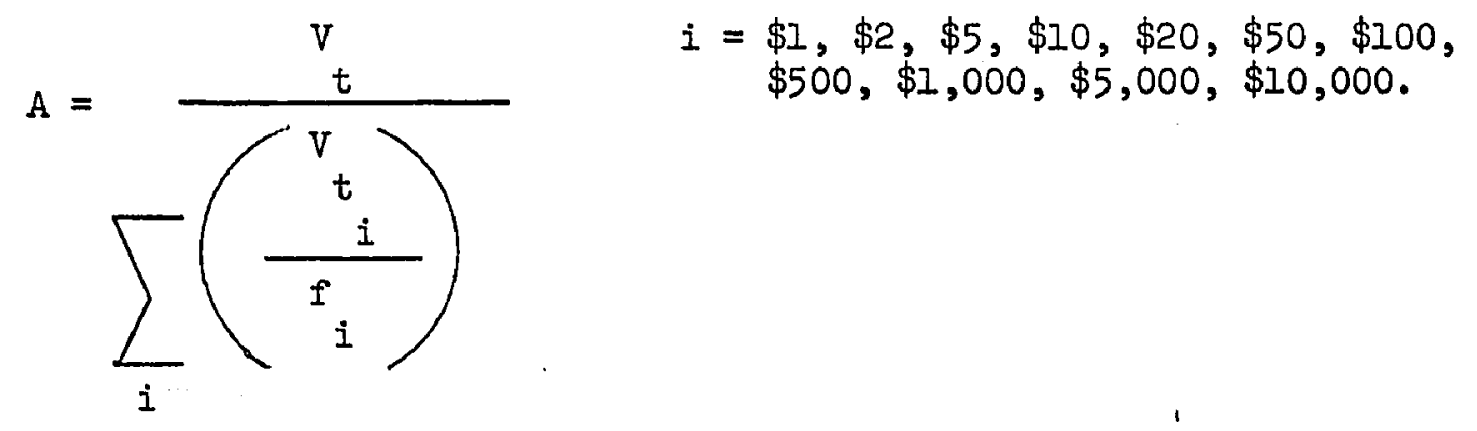

where "V $t$ " is the total dollar volume of all currency in circulation in period " $t$ "; "V $t_{i}$ " the total dollar volume of the "th" denomination in period " $t$ "; and " $f_{i}$ " the face value of the "ith" denomination. The average therefore divides the total value of currency in circulation by the total number of bills in circulation.

The average denomination can serve as a useful conceptual device for tracing changes in the distribution of denominations over time, as

. will be shown for the period $1914-65$ in Chapter II. A rise in the average denomination can result from either of the following: (I) a transfer of currency assets from small ( $\$ 20$ or less) bills to large ( $\$ 50$ or more) ones, or (2) any distributional change within a given category which 
increases holdings of higher-valued bills relative to holdings of all bills in that category (e.g., the exchange of $\$ 5$ and $\$ 10$ for $\$ 20$ bills, or of $\$ 50$ and $\$ 100$ for $\$ 500$ bills). Conversely, a fall in the average denomination can result from (I) shifts from large to small bills or (2) changes within either of these categories which boost the demand for lower-valued bills relative to the demand for all bills in that category. Given the differential transactions costs associated with different denominations, business firms and individuals will alter their holdings of denominations in response to changes in factors which influence transactions patterns. These factors parallel those which influence the demand for money in general. In the following section the demand for currency denominations is presented as a conventional demand relationship, involving the prices of substitutes, income (or wealth), and tastes. A number of possible relationships between the average denomination and certain explanatory variables (including prices, interest yields, etc.) are described. Each variable is treated separately on the assumption that the others are held constant.

\section{(1) Prices of Substitutes}

The transactions for which.individuals hold currency fall into two broad categories: (1) those that are related to current consumption (or production), and (2) those that are expected to yield a return through a decline in the values of non-monetary assets. If the transactions for which one holds currency are not expected to take place in the current period, one can reduce the costs of holding currency by holding large instead of small denominations. Or, as an alternative, the temporarily $\rightarrow$ 
idle currency may be invested at interest and subsequently withdrawn from the investment when payments come due. ${ }^{4}$ Thus, the cost of holding large denominations when payments are not required in the current period is the net income foregone on interest-earning assets, which might in this case be regarded as substitutes for currency in the storing of wealth. "Net income foregone" represents the rate of return on such assets less the costs of acquiring and disposing of them. ${ }^{5}$ Since frequent withdrawals of currency from investments are unnecessary when payments are infrequent, net income foregone is positive.

The effect of a given change in interest rates upon denominational holdings depends upon (1) the magnitude of the change, and (2) individual expectations of further changes. The allocation of idle funds between large denominational currency and interest-earning assets is upset. whenever rates change, since the change alters the relative attractiveness of storing wealth in one form rather than another. One would expect to observe an inverse relationship between interest yields and the average denomination of currency. Increases in interest rates will presumably encourage individuals to transfer idle funds to interest-earning assets. Since large bills are better suited to idle "hoards" than small ones (due

${ }^{4} \mathrm{An}$ important additional possibility is that individuals may transfer currency to checking accounts which, of course, pay no interest. The existence of such accounts greatly complicates the analysis of denominational demands, since these accounts are used as both a payments medium and a means for storing wealth prior to making payments. Future research might profitably be directed to an examination of possible links between demand deposits and denominational holdings.

The importance of such costs to an individual's portfolio of assets is discussed in Baumol, loc. cit., and Tobin, loc. cit. 
to the higher storage costs of holding currency in the latter form), the rate increase would be reflected in a reduction in relative preferences for large denominations and a subsequent decline in the average denomination.

The rate change may not be sufficiently large to cover the brokerage fees associated with acquiring (and iater disposing of) the interestearning asset. 6 This problem is complicated by the possibility that individuals may regard the increase in rates as temporary. In either case they may refrain from transferring currency into interest-earning assets. If, on the other hand, the rise in rates is sufficiently large to cover brokerage fees and related costs (or if it is interpreted as an indication of permanently higher rates in the future--and therefore of fairly large increases in the future costs of holding large denominations), one could expect to observe a transfer of idle currency to interest-earning currency substitutes.

\section{(2) Income (or Wealth)}

Denominational holdings might also be related to $(a)$ changes in the purchasing power of income (occasioned by changes in the level of

6The deposit of funds in a savings account would not involve such fees, but would involve an expenditure of effort by the depositor, the value of which may exceed the value of the original interest income plus the rate change. 
prices); and (b) changes in the distribution of income (or wealth). ${ }^{7}$

The following section examines a number of possible relationships.

(a) The Influence of Prices

Prices might influence the demand for currency denominations in two different ways. With regard to measured prices, Cagan ${ }^{8}$ and Klein ${ }^{9}$ advance the argument that, since an increase in actual prices increases the average dollar volume of transactions, people will use relatively more large bills. The effect of increases in measured prices, according to this view, is a rise in the average denomination of currency. Klein suggests that this effect is so powerful at times (e.g., during the "repressed inflation" of World War II) that the

7"Wealth" is a much broader concept than "income" since it embraces all sources (both human and non-human) of income. [See Milton Friedman, Studies in the Quantity Theory of Money (Chicago: Chicago University Press, 1956), pp. 3-12]. At the present time the relative importance of income and wealth to the demand for money is the subject of heated controversy. (See, for example, Meltzer, loc. cit., R. Teigen, "Demand and Supply Functions for Money in the United States: Some Structural Estimates," Econometrica, XXXII, [0ctober, 1964], pp. 476-509).

${ }^{8}$ See Phillip Cagan, The Demand for Currency Relative to the Total Money Supply, Occasional Paper 62, National Bureau of Economic Research (New York: National Bureau of Economic Research, 1958), p. 14.

"See John J. Klein, "Price-level and Money-denomination Movements," Journal of Political Economy, IXVII, (1960), p. 369. Klein is the only writer who has thus far examined denominational demands in any detail. Separate estimates of the average denomination of both currency and of checks handled by the Federal Reserve are related to price movements between 1939 and 1958. Variations which cannot be explained in terms of prices are attributed by Klein to changes in income distribution, the volume of installment credit, and preferences for checking accounts. 
average denomination can serve as a better measure of price changes than official estimates. 10

The relationship between expected prices (as against measured prices) and the distribution of denominations is somewhat different. Expectations of price changes may cause individuals to re-evaluate their attitudes towards the risks of holding currency. Presumably, expectations of inflation will lead them to reduce their holdings of liquid assets, including currency. While such expectations would presumably result in a reduction in both transactions balances and currency "hoards", the need to maintain at least a minimum "transactions balance" in currency may mean that expected inflation bears most heavily on currency hoards, rather than on currency held for transactions purposes. To the extent that this is true, expectations of inflation may result in a reduction in the relative demand for large bills. Other things equal, the average denomination would decline. Alternatively, expectations of deflation may occasion a shift towards liquid assets (including large denominational currency), resulting in an increase in the average denomination.

(b) The Distribution of Income (or Wealth)

Variation in the average denomination of currency might also be explained in terms of changes in the distribution of income (or wealth).

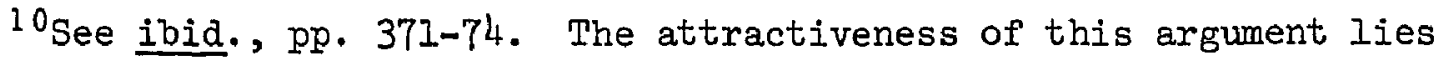
in the fact that it underscores the existence of serious biases in official price estimates (such as the consumer price index). During periods of wartime, for example, official estimates might show a downward bias, in view of the fact that they may fail to account for price behavior in black markets. The average denomination, on the other hand, would reflect changes in both official prices and black market prices and presumably would be less'biased. 
This results from the fact that the transactions for which low income individuals hold currency may be different from those for which individuals in other income categories hold currency. Once more, however, the direction of influence between the income variable and the average denomination is not easily determined.

Klein suggests that a movement towards greater equality in income distribution would have the effect of reducing the average denomination. ${ }^{11}$ His reasoning is based on the fact that low-income individuals tend to devote a larger portion of their income to the purchase of low- and medium-priced goods. As noted earlier, the transactions costs associated with such purchases can be reduced by holding small denominations of currency. Under such circumstances, Klein argues, the receipt of more income by low-income individuals implies that relatively more low- and medium-priced articles would be purchased and that relatively more lowdenomination currency would be used. The result would presumably be a decline in the average denomination.

The essential" flaw in Klein's argument is that it does not allow for the possibility that individuals in low-income categories might use currency as a repository of wealth to a greater extent than individuals in high income categories. ${ }^{12}$ In this case, the receipt of more income $11_{\text {See ibid. }}$, p. 377 .

12 Postwar surveys show that between a quarter and a third of consumer units hold no liquid assets other than currency. Although these individuals are distributed in all income and occupational groups, "the majority are concentrated in the lowest income categories and occupationally are listed as unskilled and service workers or retired." (See Federal Reserve Bank of Boston, New England Business Review, December, 1965, p. 8.) 
by persons in the former group might be expected to result in a rise in relative demands for larger bills, and an increase in the average denomination. The ability of such individuals to store wealth in the form of currency is, of course, constrained by their incomes. A reasonable assumption is that their currency hoards generally contain higher small denominations (i.e., $\$ 10$ and $\$ 20$ bills), rather than actual large denominations (i.e., bills valueâ at $\$ 50$ or more).

The existence of demand deposits greatly complicates the analysis of the role of income in the distribution of denominations. Cagan ${ }^{13}$ -has suggested that increases in real per capita income might lead individuals to switch funds from currency to demand deposits. The net effect of such transfers on the average denomination is difficult to determine and depends, once more, on the type of transactions for which the majority of low-income people hold currency. If these transactions are primarily associated with small denominations, as Klein suggests, transfers from currency to demand deposits (occasioned by rising incomes) might be accompanied by a decrease in relative holdings of small denominations and a subsequent increase in the average denomination. As noted earlier, however, it is difficult to determine whether this is in fact the case. ${ }^{14}$ The possibility that currency formerly held as a

${ }^{13}$ See Phillip Cagan, Determinants and Effects of Changes in the Stock of Money, 1875-1960 (New York: National Bureau of Economic Research, 1965), p. 126 .

${ }^{14}$ Statistics on the distribution of currency denominations by income group are not available. 
repository of wealth might also be transferred to demand deposits complicates matters and makes a priori judgments impossible.

\section{(3) Tastes and Preferences}

Changes in income may serve as a proxy for other factors wich, on balance, alter the way people hold their wealth or make payments. - Rising real income may induce changes in attitudes towards the use of credit facilities for making payments or deposit accounts for storing wealth. Income growth may also be accompanied by increased efforts on the part of certain individuals to evade taxes. By altering transactions patterns such factors may influence the demand for currency denominations. A number of possible relationships between changes in preference patterns and the average denomination are suggested below.

(a) Tax Evasion and Black Market Transactions

Kahn 15 suggests that increases in tax rates applied to the income of professional persons and unincorporated businesses during World War II had the effect of encouraging tax evasion by these groups. Since the income of these parties was not subject to withholding or the usual sort of reporting, they had the opportunity to conceal part of their income by requesting payment in currency or transferring other forms of wealth into currency. As noted earlier, the costs of such activities can be reduced through the use of large denominational currency, since large bills are less expensive to store and (at least prior to 1945) were less

${ }^{15}$ See C. Haxry Kahn, Business and Professional Income Under the Personal Income Tax, (Princeton: Princeton University Press, 1964). The possibility of tax evasion by these groups has long been recognized by Federal authorities. 
conspicuous to use for such purposes. Ceteris paribus, one would expect to find a direct relationship between the average denomination and the rate of taxation applied to the income of such groups.

A related phenomena involves the use of large denominations in "black markets." Once more there is the case of using currency to conceal the transaction. The value of the average transaction in black markets is presumably quite large. Ordinarily such transactions would be conducted in checks. However, since this would involve a permanent record of the transaction, individuals would probably use large denominations of currency instead. In so doing, they may reduce not only the storage costs of currency, but, perhaps more importantly, the risk that the transaction would be discovered. 16

Since World War II witnessed an increase in both tax evasion and black market transactions, one would expect that this period would also be accompanied by an increase in the average denomination of currency. This point is taken up in Chapter II.

\section{(b) Consumer Credit}

Consumer credit permits people to extend over a period of time obligations which they would otherwise have to meet immediately. The use of such facilities may alter the size of the average payment made to retailers (or to their finance company collectors), and this might result in a change in the distribution of denominations. Although judgments about the link between consumer credit and the average denomination are highly speculative, we can narrow the possibilities.

${ }^{16}$ See Cagan, The Demand for Currency, pp. 13-15. 
In the first place, it might be reasonably assumed that the extension of consumer credit results in a certain "lumping" of payments for small purchases, against which individuals might otherwise hold small bills. Ceteris paribus, one would expect this lumping to result in an increase in the average payment made to retailers; that is, less frequent, larger-valued payments might be made. To the extent that these payments are made in currency (rather than in checks) one might expect the average denomination to rise.

But this ignores a number of other. important possibilities. Consumer credit not only permits individuals to lump together payments for small purchases, but also to make small weekly or monthly payments for high-valued purchases, which might otherwise have been paid for with large bills. The latter purchases can be made by check or even by small bills. The net effect of consumer credit on the average denomination is therefore indeterminate, 17 since a priori judgments as to the impact of increased use of credit facilities on the value of the average payment to retailers are not possible. Moreover, even if this information were available, judgments would be difficult unless more were known about the relative importance of checks (as against currency) in the making of payments.

$17 \mathrm{Klein}$ argues (we believe incorrectly) for an inverse relationship between consumer credit and the average denomination. His statement that "with increased use of installment credit...the extension of the payment of high-price commodities over a length of time will mean that the average denomination of any payment will decline" ignores the possibility that a substantial lumping of payments for small purchases might occur: (See Klein, op. cit., pp. 373-74). 
(c) Economic and Political Stability

Individual preferences for particular denominations might also be linked to the degree of economic and political stability. Adverse expectations concerning the possibility of war or depression may result in a transfer of wealth to currency in general (and large denominations in particular) as inoividuals attempt to protect their wealth against misfortune.

Friedman, 18 for example, notes a strong positive relationship between the number of bank failures and the total circulation of currency (relative to the total money supply) during the 1930's. Declining confidence in the ability of banks to make payments presumably led individuals to hoard currency to protect their wealth against further bank failures. Individual banks may have contributed to this by substi- ' tuting notes for deposits as reserves. Since, for reasons noted earlier, larger denominations are better suited to hoards than smaller ones, one might expect to observe a sharp increase in the average denomination during the early 1930's.

Alternatively, denominational demands might be related to foreign hoarding ${ }^{19}$ during periods of economic crisis. The economic and political uncertainties generated by war and depression have historically resulted in such measures as exchange control, devaluation, etc. Quite

18 See MiIton Friedman and Anna Schwartz, A Monetary History of the United States, 1867-1960, (Princeton: Princeton University Press, 1963), pp. 346-47.

19 There is at present no satisfactory way to test the following argument, since statistics on denominations of U.S. currency carried abroad are unavailable. 
possibly, these measures will lead to greatly increased demands for highly liquid, movable assets. U.S. currency (as against foreign currency or tangible personal property) has historically met this need. In effect, the imposition of exchange controls or a currency devaluation by a foreign government makes the dollar more valuable to those individuals wishing to avoid such controls. Given the lower storage costs associated with large denominations, foreigners would probably transfer part of their own wealth to these denominations, whenever possible. A return to "normalcy" would presumably be accompanied $b_{j}$ a dishoarding of large denominations of U.S. currency by foreigners, as confidence in their own domestic currency is restored.

\section{(d) Miscellaneous Influences}

Preferences for particular denominations of U.S. currency are undoubtedly shaped by considerations in addition to those indicated above. Cagan's findings, 20 for example, suggest that a link may exist between the mobility of the population and presence of U.S. troops abroad, on the one hand, and aggregate currency holdings on the other. While the precise effect of such factors on the distribution of denominations is by no means certain, one possibility is that greater travel by U.S. citizens (particularly overseas) might increase the demand for currency (especially the easier-to-carry large denominations). A difficulty is that statistics on denominations of currency carried abroad are not available, which makes this point somewhat conjectural.

${ }^{20}$ See Cagan, op. cit., pp. 15-17. 
(c) Summary of Expected Relationships

By analysing the relationship between currency denominations and the variables upon which the total demand for money might theoretically depend, one learns something about the demand for money in general. In this chapter a number of possible relationships between the average denomination of currency and these variables have been presented. We suggest that, given the differential transactions costs between denominations, the average denomination will:

(1) vary directly with measured prices, the rate of taxation applied to the incomes of professional persons and unincorporated businesses, the extent of black markets, the degree of population mobility, and the use by foreign governments of such devices as exchange controls and devaluation during the periods of economic and political uncertainty;

(2) vary directly with the extent of inequality in the distribution of income or wealth, so long as the currency holdings of low-income individuals are primarily related to current consumption and not to "hoards";

(3) vary inversely with expected prices, the yield on interestearning currency substitutes, and the level of public confidence in the ability of U.S. banks to make payments;

(4) vary inversely with the extent to which consumer credit is used, so long as a substantial lumping of payments for small purchases does not occur. 
CHAPTER II

Secular Variation in Denominational Demands, 1914-65

Changes in the distribution of denominations of U.S. currency since $1914^{l}$ raise questions of unusual interest to the student of money. Developments over the past half-century have greatly altered the forms in which payments are made and wealth is stored. As a transactions medium, currency now plays a secondary role (at least in quantitative terms) to demand deposits and credit cards. Its relative importance as a means.for storing wealth has also declined as other assets (including time deposits and corporate and government securities) have come into widespread use. Yet, in spite of these developments, the currency stock registered an impressive twelve-fold increase between 1914 and 1965. To a large extent this reflects the growth in the needs of trade over this period. It might also be linked to long-term inflationary pressures and frequent economic crises (including two World Wars and a major depression).

In view of these developments, one might reasonably expect to observe very wide fluctuations in the average denomination of currency between 1914 and 1965. But the historical evidence does not support this. The overall trend in the average between June, 1914 and December, 1965 , was moderately upward (from \$6.20 to \$9.29). At no time during the sample

${ }^{1}$ See Tables $1-3$ and Figures 1-3. The ratios which they depict show the value of a given denomination (or grouping of denominations) as a percentage of total currency in circulation. 
TABLE 1

VALUE OF AN AVERAGE UNIT OF PAPER CURRENCY

IN CIRCULATION IN THE UNITED STATES,

$$
1914-65^{*}
$$

\begin{tabular}{|c|c|c|c|}
\hline Year & Mean Value & Year & Mean Value \\
\hline 1914 & $\$ 6.20$ & $\begin{array}{l}1940 \\
1942\end{array}$ & $\begin{array}{r}\$ 6.93 \\
7.18\end{array}$ \\
\hline 1915 & 7.09 & 1942 & 7.70 \\
\hline 1916 & 7.61 & 1943 & 8.39 \\
\hline 1917 & 8.36 & 1944 & 9.38 \\
\hline 1918 & 8.97 & & \\
\hline 1919 & 7.20 & $\begin{array}{l}1945 \\
1946\end{array}$ & $\begin{array}{r}9.80 \\
10.06\end{array}$ \\
\hline 1920 & 7.64 & 1947 & 10.32 \\
\hline 1921 & 7.05 & 1948 & 10.26 \\
\hline 1922 & 7.40 & 1949 & 10.20 \\
\hline 1923 & 7.52 & & \\
\hline 2924 & 7.43 & $\begin{array}{l}1950 \\
1951\end{array}$ & $\begin{array}{r}10.00 \\
9.83\end{array}$ \\
\hline 3925 & 7.03 & 1952 & 9.84 \\
\hline 1926 & 6.87 & 1953 & 9.89 \\
\hline 1927 & 6.67 & 1954 & 9.88 \\
\hline 1928 & 6.41 & & \\
\hline 1929 & 5.75 & $\begin{array}{l}1955 \\
1956\end{array}$ & $\begin{array}{l}9.74 \\
9.66\end{array}$ \\
\hline 1930 & 5.35 & 1957 & 9.58 \\
\hline 1931 & 5.82 & 1958 & 9.42 \\
\hline 1932 & 7.09 & 1959 & 9.28 \\
\hline 2933 & 7.18 & & \\
\hline 1934 & 6.53 & 1960 & 9.28 \\
\hline & & 1961 & 9.25 \\
\hline 1935 & 6.43 & 1962 & 9.27 \\
\hline 1936 & 6.51 & 1963 & 9.39 \\
\hline 1937 & 6.42 & 1964. & 9.39 \\
\hline 1938 & 6.53 & 1965 & 9.42 \\
\hline 1939 & 6.66 & & \\
\hline
\end{tabular}

SOURCE: Federal Reserve Bulletin (February issues, 1932-66); Annual Reports of U. S. Treasury Department, 1914-31.

* as of June 30 . 
Fig. 1,--Value of an average unit of paper currency In circulation in the United States, 191465. (as of June 30 ).

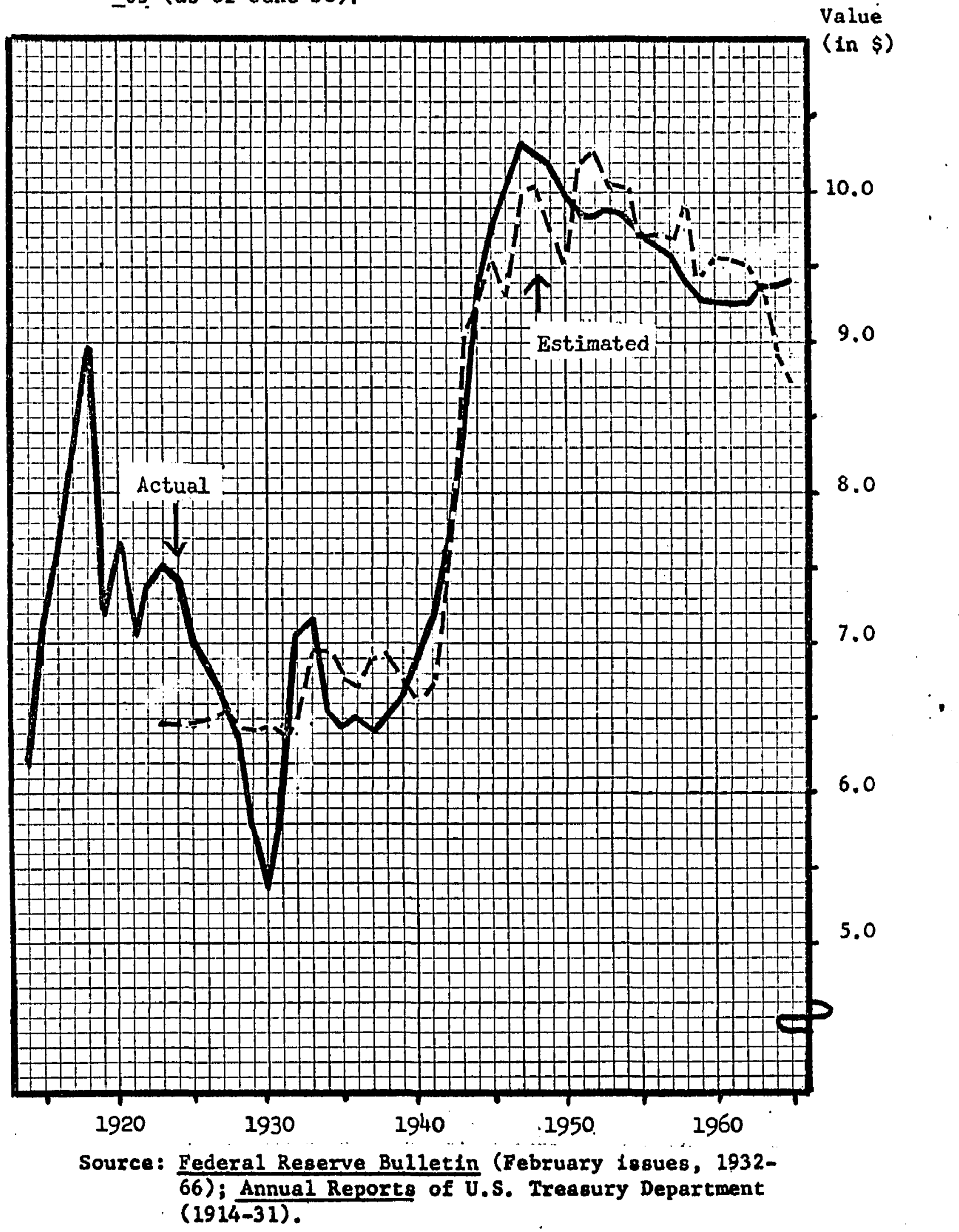


TABLE 2

DISTRIBUTION RATIOS OF CURRENCY DENOMINATIONS

IN THE UNITED STATES, $1914-32 a$

\begin{tabular}{|c|c|c|c|c|c|c|c|c|c|c|c|}
\hline \multirow[b]{2}{*}{ Year } & \multirow{2}{*}{$\begin{array}{l}\text { Dollars } \\
\\
\text { Total } \\
\text { Cur- } \\
\text { rency }\end{array}$} & & \multicolumn{9}{|c|}{ Percent } \\
\hline & & $\begin{array}{l}\text { Small } \\
\text { Denomina- } \\
\text { tion } \\
\text { Bills } \\
\text { and } \\
\text { Coin }\end{array}$ & $\begin{array}{l}\text { Gold } \\
\text { Coin }\end{array}$ & $\begin{array}{r}\text { Other } \\
\text { Coin }\end{array}$ & $\begin{array}{l}\text { Total } \\
\text { Small } \\
\text { Denomina- } \\
\text { tion } \\
\text { Bills }\end{array}$ & $\$ 1$ & $\$ 2$ & $\$ 5$ & $\$ 10$ & $\begin{array}{c}\$ 20 \\
.\end{array}$ & $\begin{array}{c}\text { Total }^{\mathrm{b}} \\
\text { Large } \\
\text { Denominatioli } \\
\text { Bills }\end{array}$ \\
\hline $\begin{array}{l}1914 \\
1915 \\
1916 \\
1917 \\
1918 \\
1919\end{array}$ & $\begin{array}{l}3,172 \\
3,032 \\
3,362 \\
3,781 \\
4,196 \\
4,589\end{array}$ & $\begin{array}{l}.809 \\
.735 \\
.684 \\
.683 \\
.699 \\
.747\end{array}$ & $\begin{array}{l}.102 \\
.099 \\
.101 \\
.101 \\
.060 \\
.041 .\end{array}$ & $\begin{array}{l}.090 \\
.093 \\
.089 \\
.088 \\
.088 \\
.085\end{array}$ & $\begin{array}{l}.616 \\
.543 \\
.494 \\
.495 \\
.551 \\
.621\end{array}$ & $\begin{array}{l}.054 \\
.043 \\
.040 \\
.033 \\
.028 \\
.054\end{array}$ & $\begin{array}{l}.020 \\
.018 \\
.018 \\
.016 \\
.016 \\
.017\end{array}$ & $\begin{array}{l}.169 \\
.164 \\
.153 \\
.136 \\
.128 \\
.124\end{array}$ & $\begin{array}{l}.221 \\
.200 \\
.180 \\
.191 \\
.222 \\
.198\end{array}$ & $\begin{array}{l}.151 \\
.118 \\
.103 \\
.118 \\
.158 \\
.228\end{array}$ & $\begin{array}{l}.191 \\
.265 \\
.316 \\
.317 \\
.301 \\
.253\end{array}$ \\
\hline $\begin{array}{l}1920 \\
1921 \\
1922 \\
1923 \\
1924\end{array}$ & $\begin{array}{l}5,180 \\
4,624 \\
4,175 \\
4,537 \\
4,561\end{array}$ & $\begin{array}{l}.756 \\
.763 \\
.719 \\
.726 \\
.724\end{array}$ & $\begin{array}{l}.036 \\
.035 \\
.031 \\
.026 \\
.023\end{array}$ & $\begin{array}{l}.081 \\
.085 \\
.090 \\
.088 \\
.089\end{array}$ & $\begin{array}{l}.640 \\
.643 \\
.598 \\
.612 \\
.612\end{array}$ & $\begin{array}{l}.048 \\
.055 \\
.052 \\
.050 \\
.053\end{array}$ & $\begin{array}{l}.014 \\
.016 \\
.015 \\
.013 \\
.011\end{array}$ & $\begin{array}{l}.122 \\
.133 \\
.132 \\
.138 \\
.138\end{array}$ & $\begin{array}{l}.208 \\
.208 \\
.197 \\
.191 \\
.196\end{array}$ & $\begin{array}{l}.247 \\
.232 \\
.203 \\
.220 \\
.214\end{array}$ & $\begin{array}{l}.244 \\
.237 \\
.281 \\
.274 \\
.276\end{array}$ \\
\hline $\begin{array}{l}1925 \\
1926 \\
1927 \\
1928 \\
1929\end{array}$ & $\begin{array}{l}4,525 \\
4,599 \\
4,563 \\
4,509 \\
4,459\end{array}$ & $\begin{array}{l}.730 \\
.745 \\
.751 \\
.752 \\
.850\end{array}$ & $\begin{array}{l}.025 \\
.023 \\
.021 \\
.020 \\
.018\end{array}$ & $\begin{array}{l}.092 \\
.093 \\
.095 \\
.096 \\
.099\end{array}$ & $\begin{array}{l}.614 \\
.630 \\
.635 \\
.636 \\
.733\end{array}$ & $\begin{array}{l}.061 \\
.063 \\
.067 \\
.072 \\
.078\end{array}$ & $\begin{array}{l}.011 \\
.011 \\
.010 \\
.009 \\
.011\end{array}$ & $\begin{array}{l}.125 \\
.128 \\
.134 \\
.140 \\
.165\end{array}$ & $\begin{array}{l}.202 \\
.206 \\
.195 \\
.194 \\
.231\end{array}$ & $\begin{array}{l}.215 \\
.222 \\
.229 \\
.221 \\
.248\end{array}$ & $\begin{array}{l}.270 \\
.255 \\
.249 \\
.248 \\
.150\end{array}$ \\
\hline $\begin{array}{l}1930 \\
1931 \\
1932\end{array}$ & $\begin{array}{l}4,235 \\
4,535 \\
5,408\end{array}$ & $\begin{array}{l}.850 \\
.818 \\
.733\end{array}$ & $\begin{array}{l}.017 \\
.017 \\
.031\end{array}$ & $\begin{array}{l}.103 \\
.094 \\
.074\end{array}$ & $\begin{array}{l}.730 \\
.708 \\
.629\end{array}$ & $\begin{array}{l}.091 \\
.082 \\
.065\end{array}$ & $\begin{array}{l}.011 \\
.009 \\
.006\end{array}$ & $\begin{array}{l}.156 \\
.142 \\
.115\end{array}$ & $\begin{array}{l}.237 \\
.229 \\
.200\end{array}$ & $\begin{array}{l}.236 \\
.246 \\
.243\end{array}$ & $\begin{array}{l}.150 \\
.206 \\
.280\end{array}$ \\
\hline
\end{tabular}

SOURCE: Federal Reserve Bulletin (February issues, 1932-6.6); Annual Reports of U.S. Treasury Department $(1914-31)$

a. as of dune 30 .

b. Denominations including $\$ 50, \$ 100, \$ 500, \$ 1,000, \$ 5,000, \$ 10,000$ bilis. 


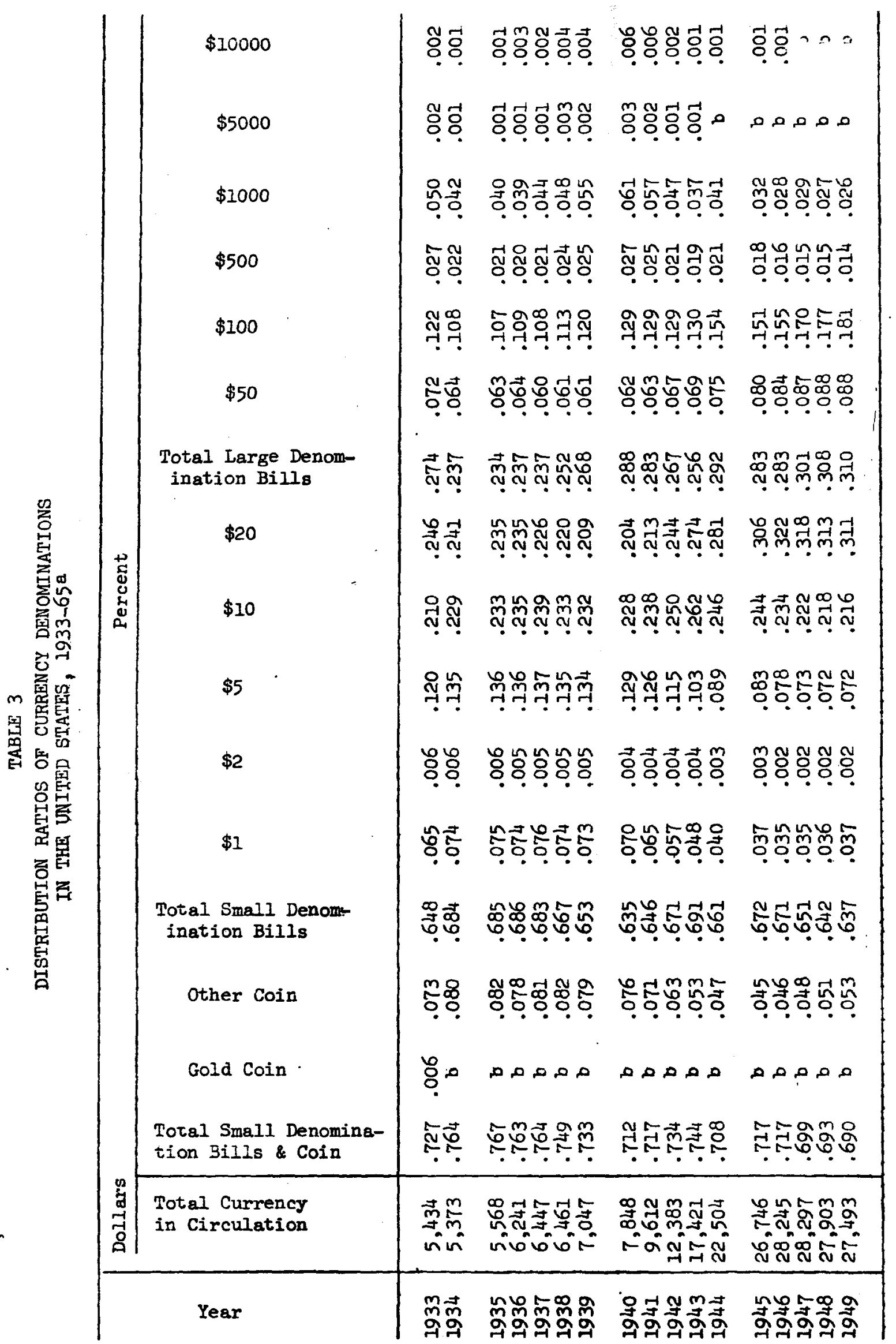




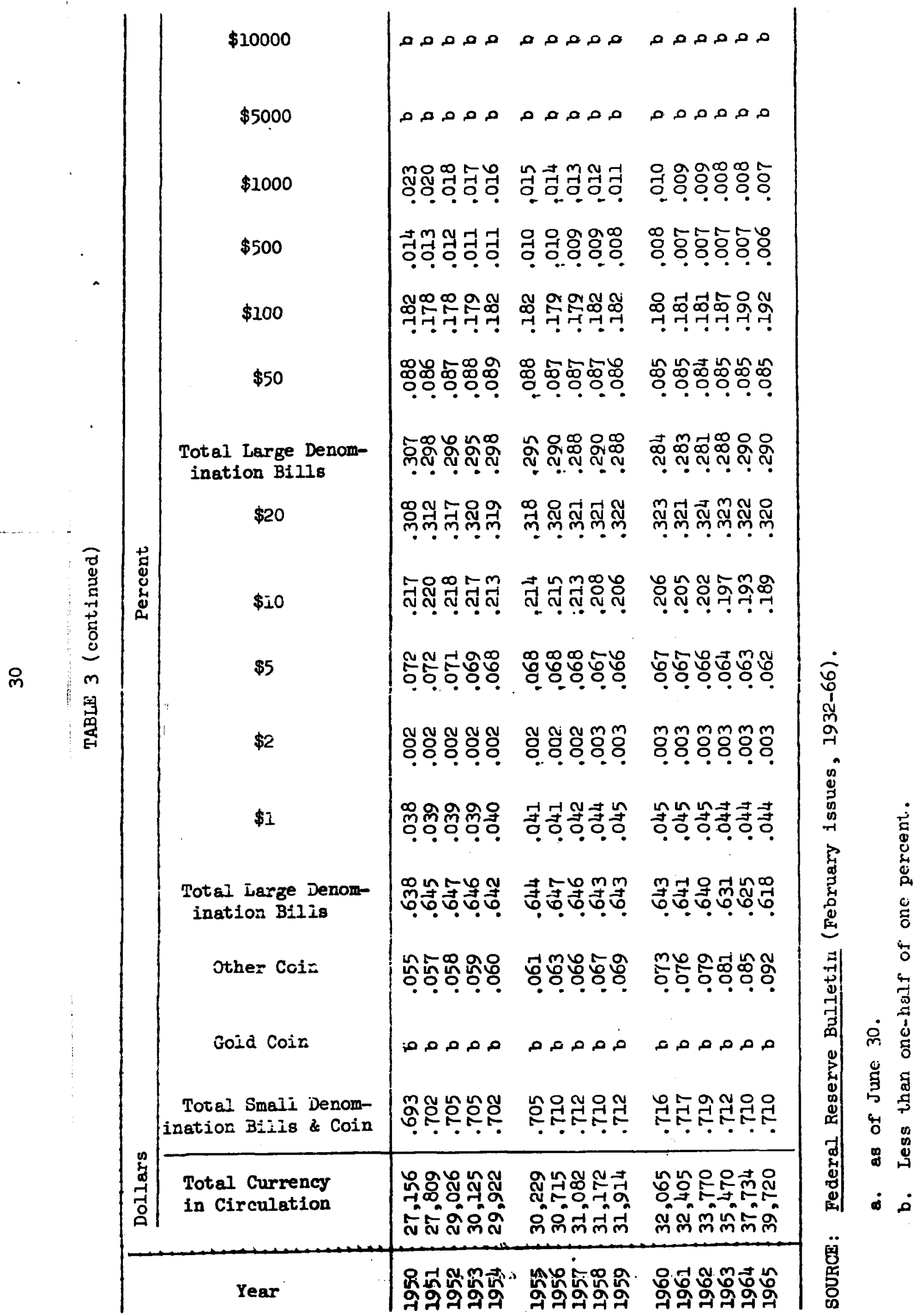


Fig. 2. --Distribution ratios for $\$ 1, \$ 5$, $\$ 10, \$ 20, \$ 50$, and $\$ 100$ denominations, 1914-65

(as of June 30 ). :

Percent

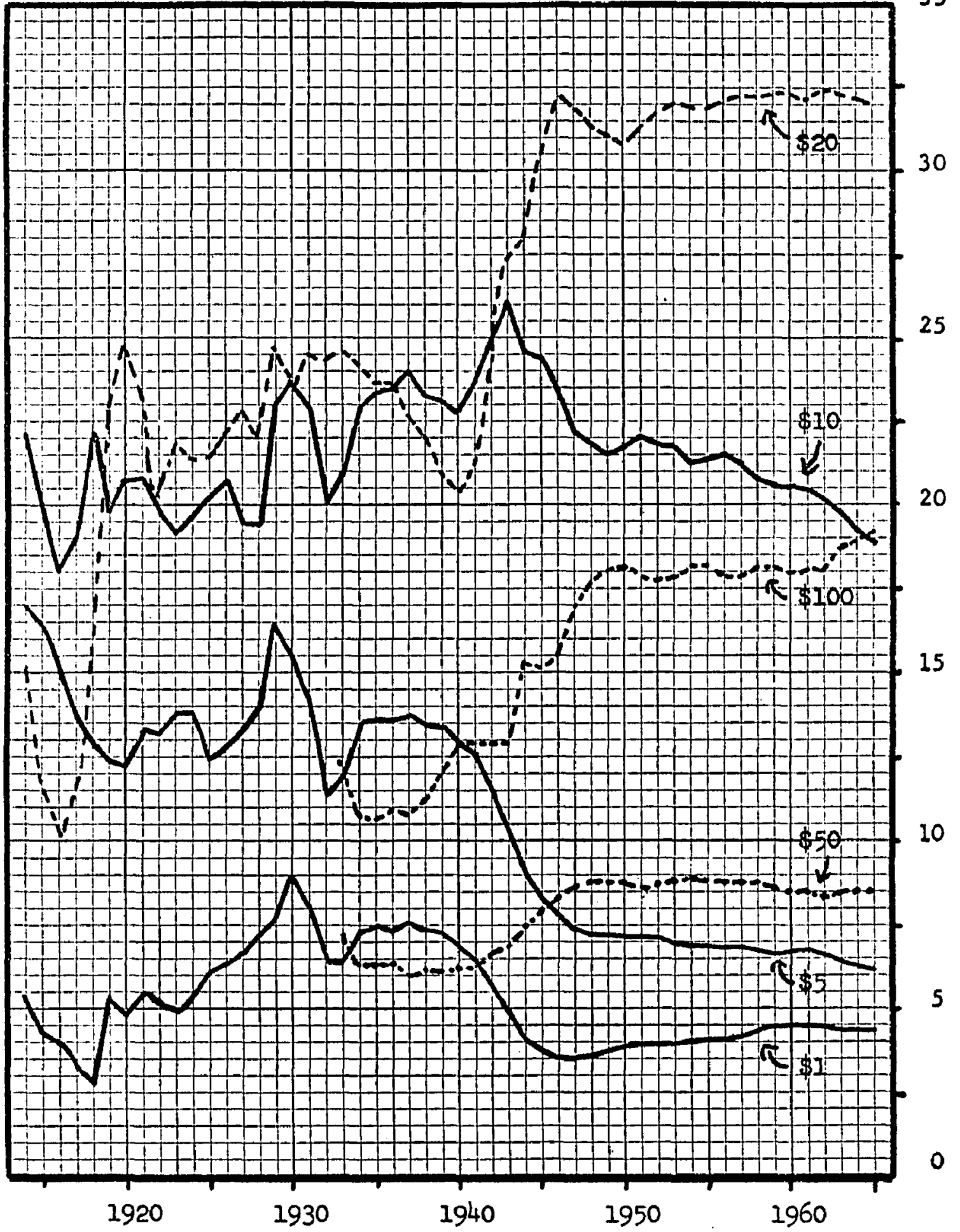

Source: Federal Reserve Bulletin (February 1ssues, 193266); Annual Renorts of U.S. Treasury Department (1914-31). 
Fig. 3.--Distribution ratios for coin, $\$ 2$, $\$ 500$, and $\$ 1,000$ denominations, 1914-65' (as of June 30).

Percent

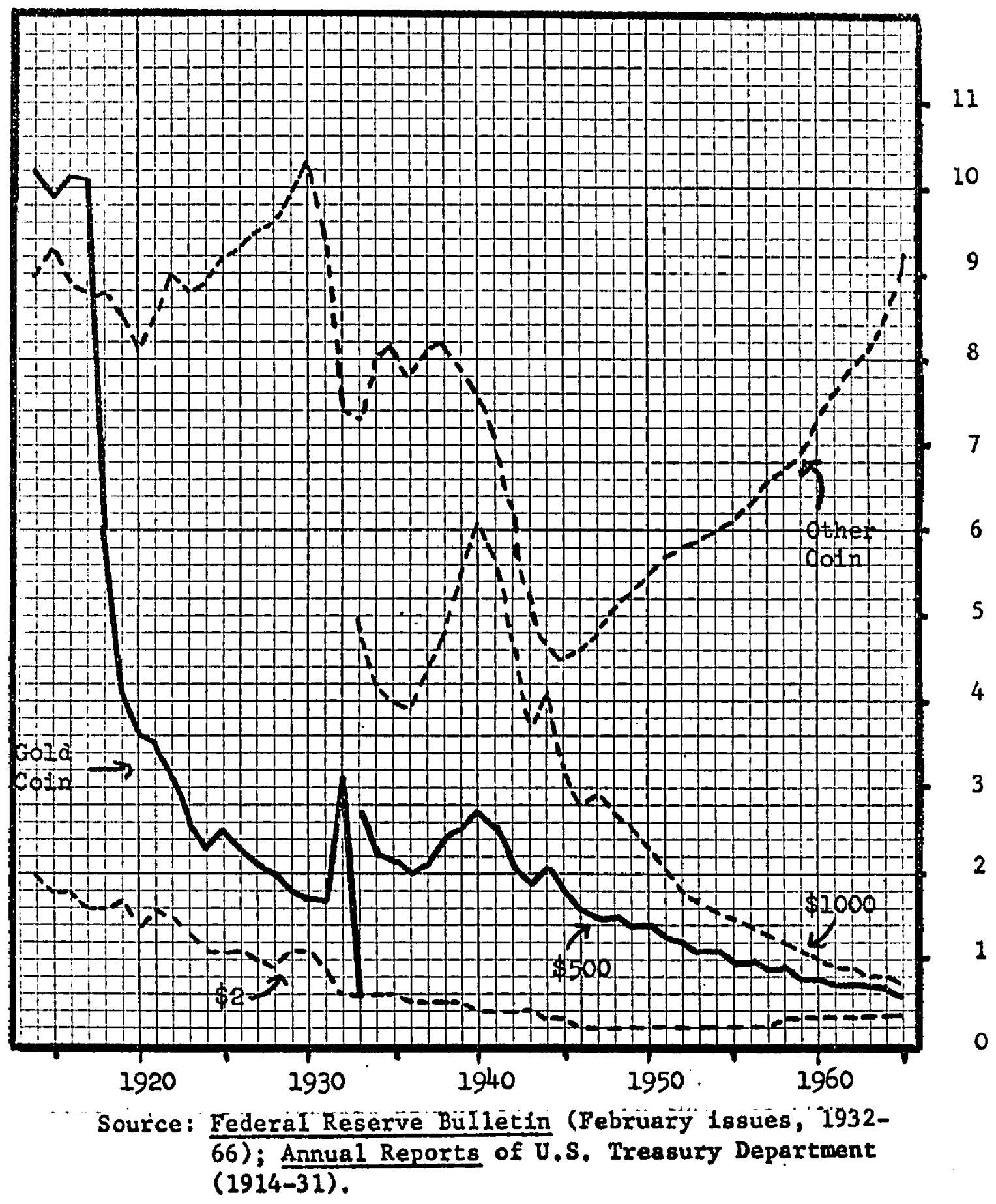


period did the average rise above $\$ 10.32$ (February, 1948) or fall below $\$ 5.35$ (June, 1930). Given large gains in the currency stock and a doubling of the cost of living over the same period, the average could have demonstrated this stability only if major changes in the denominational composition of currency holdings occurred. In this chapter we will examine these changes and attempt to explain them in terms of hypotheses set forth in the previous chapter.

\section{(A) Summary of Secular Movements in Average Denomination}

For the sake of exposition, five subperiods (paralleling major movements in the average denomination) might be distinguished:
(1) 1914-19;
(2) 1920-29;
(3) 1930-37;
(4) $1938-47$; and (5) $1948-65$.

The first and more important impressions gained from a study of these subperiods might be summarized as follows: ${ }^{2}$

(I) With minor exceptions, the only periods when the average denomination rose between 1914 and 1965 were the periods 1914-18, 1930-33, and 1938-47. Each of these periods was characterized by an economic crisis in the form of a major war or depression. As far as currency behavior is concerned, these crises produced a rise in total demands for currency relative to ordinary transactions demands for currency. The fact that individuals and business chose to hold more large bills might suggest that currency was better suited to the storing of wealth (than, for example,

2It cannot be sufficiently emphasized that statistics on denominations in circulation prior to October, 1930, are estimates and are therefore possibly subject to error. For a discussion of the estimating techniques, see Appendix A, p. 129. 
time deposits and securities) and to the making of "Iargevalued payments (than,for example, demand deposits) at such times.

(2) There is a tendency for each of these crises to be followed by a sudden decline in the average denomination. In each case the decline is quite pronounced and the largest part of it tends to occur over a twelve-month period. This might suggest that large scale currency dishoarding followed the crises, as individuals and businesses transferred their currency holdings into other non-currency stores of wealth or into smaller bills for use in making retail purchases.

(3) During the two remaining periods (1920-29 and 1948-65) the tendency is for a continuation of the decline in the average denomination. The fact that these periods were free of major wars or depressions may be of importance. The implication is that individuals and businesses were under less pressure to hold larger denominations (for the purpose of hoarding wealth or making larger valued payments) during non-crisis periods. At such times ordinary retail transactions needs for currency tended to rise relative to total needs for currency.

An examination of changes in holdings of separate denominations 2 provides support for this hypothesis. ${ }^{3}$ The period 1914-65 witnessed a

${ }^{3}$ See Figures $2-3$. 
net decline in the relative circulation of all denominations in excess of $\$ 100$ ( $\$ 500, \$ 1,000, \$ 5,000$ and $\$ 10,000$ bills): Only during periods of crisis (as in the early years of World War II) does the relative circulation of these bills increase.

The years 1914-65 also witnessed a net decline in the relative circulation of the smallest small denominations $(\$ 1, \$ 2, \$ 5$, and $\$ 10$ bills). Once more, however, crisis conditions appear to play an important role. These denominations tended to decline in relative circulation only during the two world wars and the Great Depression. During more "normal" periods the relative circulation of these bills either tended to grow (1920-29) or remain stable (1948-65).

The remaining denominations (coin, $\$ 20, \$ 50$ and $\$ 100$ bills) provide an interesting contrast to those already noted. These are the only denominations which showed a net gain in relative circulation over the 1914-65 period. The most striking increase occurred in the $\$ 20$ category (particularly during World War II). The $\$ 50$ and $\$ 100$ denominations showed more moderate gains, again with the most significant increase occurring during the Second World War. The relative circulation of coin fell off very sharply during the war, but increased dramatically in the postwar period. 4

${ }^{4}$ In the following discussion emphasis is placed on changes in holdings of $\$ 1, \$ 5, \$ 10, \$ 20, \$ 50, \$ 100, \$ 500$ and $\$ 1,000$ bilis and total coin (disaggregated prior to 1934 according to gold- and non-gold categories). The remaining denominations $(\$ 2, \$ 5,000$ and $\$ 10,000)$ are omitted from the discussion. As can be seen from Tables 2-3, all three of these denominations show little variation around a moderate downward trend. In each case the distribution ratios never rise above a slight 0.6 percent of the total currency stock and (as regards $\$ 5,000$ and $\$ 10,000$ bills in the post World War II period) the lower limit is less than 0.05 percent. 
In the following sections we examine variations in denominational demands between 1914 and 1965. Major changes in the relative demand for each denomination are noted for each subperiod. These changes are analysed in light of historical evidence, particularly with regard to explanatory variables discussed in Chapter II. Then, in Chapter IV, an attempt is made at constructing statistical demand functions for the period 1923-65.

(B) Behavior of the Distribution of Denominations During Five Subperiods, $1914-65$

(1) The First World War Period, 1914-195

An early example of the adjustment of denominations under wartime conditions is provided by the period June, 1914 to June, 1919. Although the evidence is somewhat fragmentary, there is reason to believe that the war years (1914-18) coincided with a substantial shift to large denominations of U.S. currency. This was followed by an abrupt reduction in relative holdings of these bills between 1918 and 1919.

During the first four years of this period the average denomination rose rapidly (from $\$ 6.20$ in mid-1914 to $\$ 8.97$ in mid-1918). The ratio of small bills to the total currency stock (the "small-denominations ratio") $)^{6}$ fell from 80.9 percent in 1914 to 68.4 percent in 1916, and

5 The analysis in this and the following section (which covers the period 1920-29) deals with changes in annual (June) values only, since changes in monthly values are not available until the early 1930's. A further limitation is that statistics on changes in the demands for separate large denominations cannot be determined prior to May, 1933.

"In the following sections the term "small denominations ratio" embraces both small denominations of paper currency and (gold and nongold) coin, unless otherwise noted. As such, the ratio is not strictly compatible with the average denomination, which does not include the coin component. 
remained near this level through mid-1918. Relative holdings of $\$ 1$ and $\$ 5$ bills declined steadily through mid-1918. Demands for the $\$ 10$ and $\$ 20$ denominations fell off through mid-1916, but rose thereafter: ${ }^{7}$ by mid1918 they had been restored to their 1914 levels. Holdings of the remaining denominations for which information is available (gold ${ }^{8}$ and non-gola coin) were stable-to-moderately decreasing throughout most of the war. The overall tendency between 1914 and 1918 was therefore a shift away from small denominations.

The mid-1918 to mid-1919 evidence points to a fairly sizable and abrupt dishoarding of the large bills accumulated during the war. The average denomination fell off rapidly over this twelve month period (from $\$ 8.97$ to $\$ 7.20$ ), while total holdings of small denominations climbed from 69.9 to 74.7 percent of the total currency stock. The shift to small denominations did not occur in all categories. Relative holdings of non-gold coin and $\$ 5$ bills were stable-to-moderately declining over this period, while demands for the $\$ 10$ denomination decreased fairly rapidly. However, the two remaining bills ( $\$ 1$ and $\$ 20$ ) showed rather large gains (particularly the latter denomination). Although it is

7 The $\$ 20$ bill has historically increased in relative circulation at a far greater rate than any of the "large" denominations during periods of wartime. This suggests that the traditional definition of large bills employed by the monetary authorities (and the present author) may be somewhat arbitrary and might be improved through the inclusion of the $\$ 20$ denomination.

${ }^{8}$ After remaining fairly stable through mid-1917 relative holdings of gold coin dropped off sharply for two years (from 10.1 to 6.0 percent of the tatal currency stock). This reflects the success of a campaign aimed at concentrating gold in the Federal Reserve banks. One of the goals of this campaign was to discourage individuals from withdrawing gold coins for use as gifts. (See Federal Reserve Bulletin, December 1917, pp. 931, 951). 
somewhat fragmentary, the 1918-19 evidence does point to fairly widespread currency dishoarding over this period. A number of possible reasons for these changes in the distribution of denominations between 1914 and 1919 are considered below.

(a) Wartime Adjustments

What is most interesting with regard to the denominational adjustments over the 1914-18 period is that the shift to large bills began early in the war. In part this may reflect a reaction to the 1913-14 price deflation, to the extent that individuals held more (large denominational) currency in anticipation of a rise in the real value of these holdings. In addition, the early rise in relative holdings of large bills might be interpreted in terms of the reaction of the belligerents to crisis conditions. The war had an immediate and profound effect upon the forms in which they could hold their wealth. By 1915 all belligerents had suspended the redeemability of their money in gold. In many cases gold coin and bullion had been called in by governmental authorities and the export of funds in any form was severely restricted. At the same time the methods used by the countries of Europe to finance the war had greatly decreased the purchasing power of their own currencies. Denied access to gold and unwilling to store their depleted wealth in the form of their domestic currencies, many Europeans undoubtedly turned to U.S. dollars in the early years of the war.

In addition to providing Europeans with a means of protecting their wealth against the risks of domestic currency devaluations, U.S. currency was ideally suited to black market transactions. Penalties imposed for 
these transactions by belligerent governments during World War I were quite heavy. Europeans found that they could reduce the risks of exposure (and the costs of storing their wealth in advance of the transactions) through the use of large U.S. bills. Those who were either unwilling or unable to resort to black market trading soon discovered that even in "official markets" inflation had boosted the value of the average transaction, a fact which also helps to explain the switch to higher denominations of currency early in the war.

Economic dislocations (both at home and abroad) may also have played an important part in encouraging the use of large bills. Patriotic appeals in support of the AIlies led many U.S. citizens to seek out employment in "war plants" distant from their homes. Draft calls and enlistments swelled, as the U.S. mobilized for the war. These developments significantly increased the mobility of the U.S. population and may have contributed to the rise in the demand for U.S. currency (particularly the easier-to-carry large denominations) after 1915.

U.S. entry into the war in April, 1917, undoubtedly contributed to these pressures on the distribution of denominations. Americans soon faced many of the same problems as Europeans had known since 1914, although they were in a somewhat better position to deal with them. In the first place, domestic wealth was increased rather than diminished during the course of the war. Moreover, the number of alternative forms for holding this wealth were never directly threatened (as they had been in Europe, 
through suspension of redeemability of domestic currencies in gold).9 Rationing schemes and black markets never assumed the same proportions in the United States as they did in Europe during the war and most goods could be purchased on official markets. Still, the pressures of inflation in these markets were acute. After rising moderately from 34.6 in 1914 to 37.7 in 1916, the consumer price index $(1957-59=100.0)$ began a dramatic upward climb. Two years later it stood at 51.3. Wholesale prices , registered similar gains. The tendency towards increased holdings of large bills was undoubtedly reinforced by these pressures. American business firms and individuals, like their European counterparts, found it necessary to carry higher denominations as the value of the average transaction continued to rise throughout the war.

Federal tax policy might also have contributed to this tendency. The federal income tax levied by virtue of the sixteenth amendment in 1913 and raised in 1916 was again increased in 1917. U.S. entry into the war also saw the inauguration of an "excess-profits" levy on the incomes of corporations, partnerships, and individuals. These two taxes combined yielded nearly two-thirds of the revenues necessary to support the war and, in ligint of the pre-war federal tax structure, were probably considered to be an excessive burden by some individuals and business firms. (Rates on upper bracket incomes had been raised most sharply). Part of the rise in relative holdings of large bills may have resulted from increased tax evasion on the part of those groups (i.e., professional

${ }^{9}$ While it is true that official policy discouraged Americans from requesting gold coins (on the grounds. that such requests were contrary to national interests), Americans were never prohibited from receiving these coins. 
persons and unincorporated businesses) who had the opportunity to conceal part of their incomes through requesting payment in currency.

(b) The Immediate Postwar Period: 1918-19

The abrupt decline in the average denomination (from $\$ 8.97$ to $\$ 7.20$ ) between mid-1918 and mid-1919 might suggest that large scale currency dishoarding took place. Over this period the total value of large denominational currency in circulation fell from 30.1 to 25.3 percent of the total currency stock-an absolute decline of $\$ 92.1$ million in holdings of large bills over a twelve month period. The promise of a "return to normalcy" on the Continent eliminated one of the major reasons for storing wealth in the form of large U.S. bills. Reconversion to a peacetime economy meant that goods which were previously unavailable would now be produced. In adaition, certain wartime measures which might have encouraged the use of large denominations were modified in the immediate postwar period: a case in point is a sizable reduction in federal tax levies soon after the signing of the Armistice. 10

There is reason to believe that the decline in relative holdings of large bills might have been even greater, were it not for the continuation of certain wartime trends. Pressures on prices were, if anything, increased during the immediate postwar period. Black market trading flourished on the Continent for many years after the war. In

${ }^{10} \mathrm{~A}$ further possibility is that part of the decline in relative holdings of large bills may be traced to bank management of vault cash. An amendment to the Federal Reserve Act (dated June 21, 1917) prohibited banks from counting notes as reserves. A. reasonable assumption is that part of the substantial decline in vault cash (from $\$ 1,489$ million in mid-1917 to $\$ 888$ million in mid-1918) may have been accompanied by bank "dishoarding" of large denominations. 
addition, the failure of Allied governments to restore the redeemability of their currencies in gold and to prevent further reductions in the value of their currencies relative to dollars meant that large denominations of U.S. currency continued to represent an attractive form in which Europeans could store their wealth.

(2) The Return to Normalcy: 1920-29

Although the course of increase in relative holdings of small bills during the 1920's was far from uniform, it was sufficiently pronounced to suggest a significant rise in transactions needs for currency relative to total needs for currency. Following three years of fluctuations around a moderately declining trend, the average fell off rapialy (from $\$ 7.52$ to $\$ 5.75)$ between mid-1923 and mid-1929. Over the same six year period total holdings of small denominations rose from 72.6 to 85.0 percent of the total currency stock. Except for gold coin, all small denominations of U.S. currency increased in relative circulation over the decade. A number of possible reasons for the general shift to small bills during the $1920^{\prime} \mathrm{s}^{\circ}$. are given below.

\section{(a) The Contraction of 1920-21}

This trend was not apparent at the start of the decade. Between mid-1919 and mid-1920 the average denomination increased slightly (from $\$ 7.20$ to $\$ 7.64)$, possibly reflecting renewed pressures on prices at the close of the decade. 11 This was followed by another decline in the average denomination (to $\$ 7.05$ ) between mid-1920 and mid-1921: relative

Il In the United States the consumer price index fumped from 59.0 in mid-1919 to 72.9 in mid-1920. Even more striking gains in prices were registered in Western Burope during this period. 
holdings of each of the smaller small denominations rose, while demands for $\$ 10$ bilis remained stable and holdings of $\$ 20$ bills declined. In part this may reflect a continuation of the tendency to dishoard large bills which had been accumulated during the war. ${ }^{12}$ An additional possibility is that public demands for the larger denominations may have been influenced by the contraction of 1920-21, which resulted in one of the most severe price declines in U.S. history. 13 Within a single year (June, 1920, to June, 1921) the consumer price index fell from 72.9 to 61.4. Faced with an abrupt and sizable decline in the value of the average transaction, individuals may have found it unnecessary to carry as many of the higher-valued denominations as they previously had to carry.

The evidence for the next two years (mid-1921 to mid-1923) points to a sudden alteration in currency behavior. Between 1921 and 1922 the average denomination rose once more (to $\$ 7.40$ ), while relative holdings of small denominations registered a rather sharp decline (from 76.3 to 71.9 percent of the total currency stock). This decline occurred in all small denominational categories, except for non-gold coin. The transfer of currency to large bills may reflect in part a lagged adjustment to the 1920-2I contraction. Given the severity of the price decline, there is

12 the public "dishoarded" \$65.1 million in large bills between mid-1919 and mid-1921. This was roughly seven-tenths of the total. reduction in holdings of large denominations during the mid-1918 to mid-1919 period.

13 The "only possible competitors (of the 1920-21 contraction)," according to Friedman and Schwartz, "are the price declines that followed the War of 1812 and the Civil War... (It represents), by all odds, the sharpest price decline (between 1867 and 1960) and perhaps also in the whole history of the United States." (Friedman and Schwartz, op. cit., p. 232). 
reason to believe that some individuals and businesses might have increased their demands for currency in anticipation of a substantial rise in the real value of their money holdings. For reasons noted earlier, one can associate hoarding with a rise in the relative circulation of large bills. The rise in the average denomination between mid-1921 and mid-1922 may also be associated with the large number of commercial bank suspensions over this period. The total number of suspensions in 1921 and 1922 was quite large (872). A reasonable assumption is that this may have led to a general decline in public confidence in the ability of banks to make payments. By holding their wealth in the form of currency (rather than bank deposits), individuals were able to reduce the risks of losing this wealth through bank failures.

The currency evidence suggests that these factors continued to influence the distribution of denominations at least through mid-1923: between mid-1922 and mid-1923 the average denomination rose slightly (to \$7.52). During the following year, however, the upward trend in the average was abruptly halted, as individuals and businesses once more began to build up their relative holdings of small bills. This trend towards increased use of small denominations continued throughout the remainder of the decade.

\section{(b) The Declining Importance of Large Bills: 1923-29}

With few exceptions ${ }^{14}$ each year from 1923 to 1929 is associated with impressive gains in the relative circulation of each of the small

${ }^{14}$ The major exception (noted earlier) is a decline in relative holdings of gold coin, which might reflect the success of official policies aimed at concentrating gold in central banks. In addition, there were temporary declines in relative holdings of \$1 bills (between 1924 and 1925), \$5 bills (1924-25), \$10 bills (1926-27) and \$20 bills (1923-24, $1927-28)$. 
currency denominations. Between mid-1923 and mid-1929 total holdings of these bills rose from 72.6 to 85.0 percent of the total currency stock, while the average denomination fell from $\$ 7.52$ to $\$ 5.75$ (its lowest point since 1914).

Changes in the distribution of denominations between 1923 and 1929 are related to a number of postwar developments 15 in the following section.

\section{(i) Retail Trade}

Although the evidence is fragmentary, the shift to small bills may first of all be associated with an increase in the volume of those retail transactions with which we associate small denominations. ${ }^{16}$ Between 1922 and 1926 the average annual output of perishable and semi-durable consumer goods was \$32.6 billion, as against \$16.4 billion between 1912 and 1916. It might be reasonably assumed that the increase in sales of non-durable consumer goods involved a rise in the demand for small denominations of currency.

${ }^{15}$ Certain students of the subject suggest that the two World Wars and Great Depression set into motion forces which continued to affect currency behavior for a considerable time after their disappearance. (See, for example, George Kaufman, The Demand for Currency, Staff Economic Studies [U.S. Board of Governors of the Federal Reserve System, 1966], p. 22).

${ }^{16}$ Ideally, it would be possible to associate the increase in relative holdings of small denominations with a rise in the volume of retail purchases of "small ticket" items (i.e., lower-priced retail goods). There are no fully adequate statistics on "small ticket" sales. Presumably, statistics on non-durable retail sales might serve as a reasonably good proxy, since a large part of such transactions are handled in small denominations of currency. Estimates of "total sales of non-durable goods at retail stores" are available on an annual basis since 1929 (with the exception of several. years in the 1930's). Prior to 1929 the only comparable series represents five year annual averages of the output of perishable and semi-durable consumer goods. (See Department of Commerce, Bureau of the Census, Historical Statistics of the United States: Colonial Times to 1957. [Washington, D.C., 1960], pp. 143, 519]. 
(ii) Growth of Alternative Stores of Wealth

The shift towards small bilis may also be associated with the rapid growth of intangible assets over the decade. (See Table 4).17 During both the First World War and the decade which followed it total national assets grew rapidly (with particularly large gains occurring in the intangibles component of these assets). Over the war years currency tended to grow apace with other intangible assets. However, during the 1920's the currency stock fell, as other intangible assets (particularly bank deposits and non-governmental securities) showed rather striking gains. The dollar volume of corporate equities jumped from $\$ 76.1$ billion in 1922 to $\$ 186.7$ billion in 1929 , while dollar holdings of corporate bonds grew from $\$ 23.7$ billion to $\$ 38.1$ billion over the same period. Commercial bank deposits rose from $\$ 34.2$ billion (1922) to $\$ 44.8$ billion (1929), while deposits in other financial institutions increased from $\$ 10.5$ billion to $\$ 17.9$ billion. Time deposits in commercial banks showed a gain in excess of 75 pexcent over this period, while demand deposits grew by more than 30 percent. 18 In contrast, the currency stock fell from $\$ 6.9$ billion to $\$ 6.5$ billion between 1922 and 1929 .

The evidence may suggest that individuals and businesses transferred a large share of their currency holdings into other non-currency stores. of wealth between 1923 and 1929. The implication is that these

17 The estimates originally appeared in Raymond W. Goldsmith, et al., A study of Saving in the United States (Princeton: Princeton University. Press, 1956), pp. 60-61.

18 The attractiveness of demand deposits as a means for storing wealth was enhanced during the 1920's by the fact that such accounts frequently did not involve service charges and sometimes yielded an interest return. 
TABLE 4

SELECTED COMPONENTS OF NATIONAI, WEALTH, IN THE UNITED STATES, 1912-1955 (bilitions of current dollars; as of end of year)

\begin{tabular}{|c|c|c|c|c|c|c|c|c|}
\hline Type of Asset & 1.912 & 1922 & 1.929 & 1933 & 1939 & 1945 & 1949 & 1955 \\
\hline \multicolumn{9}{|l|}{ INTANGIBLE ASSETS } \\
\hline Total & 141.0 & 326.8 & 554.8 & 410.7 & 482.2 & 987.2 & $1,134.7$ & $1,745.0$ \\
\hline Currency & 2.5 & 6.9 & 6.5 & 8.1 & 22.4 & 45.0 & 49.0 & 54.0 \\
\hline \multirow{3}{*}{$\begin{array}{l}\text { Peposits in: } \\
\text { Commercial banks } \\
\text { Other financial } \\
\text { Institutions }\end{array}$} & & & & & & & & \\
\hline & 15.8 & 34.2 & 44.8 & 36.2 & 54.1. & 137.9 & 131.1 & 145.0 \\
\hline & 4.5 & 10.5 & 1.7 .9 & 18.8 & 28.8 & 44.0 & 53.4 & 112.0 \\
\hline \multirow{3}{*}{$\begin{array}{l}\text { Securities: } \\
\text { U.S. government } \\
\text { State and local } \\
\text { governments }\end{array}$} & & 220 & 162 & & & & & \\
\hline & 1.2 & 23.0 & 10.2 & 23.9 & 47.0 & 274.4 & 253.3 & 272.0 \\
\hline & 4.4 & 10.4 & 16.9 & 19.1 & 19.8 & 15.9 & 21.9 & 46.0 \\
\hline Corporate bonds & 14.5 & 23.7 & 38.1 & 37.7 & 32.5 & 25.9 & 39.5 & 69.0 \\
\hline $\begin{array}{l}\text { Preferred and } \\
\text { common stock }\end{array}$ & 38.0 & 76.1 & 186.7 & 101.7 & 100.1 & 150.8 & 158.8 & 437.0 \\
\hline \multicolumn{9}{|l|}{ Mort geges: } \\
\hline Nonfarm & 7.5 & 16.3 & 37.3 & 33.5 & 32.0 & 33.1 & 60.8 & 121.0 \\
\hline Farm & 4.3 & 10.8 & 9.6 & 7.7 & 6.6 & 4.7 & 5.4 & 9.0 \\
\hline $\begin{array}{l}\text { TOTAL NATIONAI } \\
\text { ASSETS }\end{array}$ & 308.6 & 653.0 & 981.8 & 733.1 & 877.2 & $1,557.5$ & $2,016.0$ & $3,074.0$ \\
\hline
\end{tabular}

SOURCE: U.S. Department of Commerce, Historical Statistics of the United States, Colonial Times to 1957 , Washington, D.C., 1960, p. 150 . 
assets were relatively more attractive as a means for storing wealth than was currency. This might be attributed to the fact that yields payable on such assets were quite high throughout the decade. 19 The decline in the average denomination may reflect this development.

\section{(iii) The Behavior of Prices}

For the duration of the decade, consumer prices remained fairly stable. After rising moderately between 1923 and 1925, they began a mild decline, which extended through the second quarter of 1929. This contrasts sharply with the severe inflationary pressures of the war years and may have relevance to the distribution of denominations on several counts.

In the first place, price trends after 1923 indicate that strong upward pressures on the value of the average transaction (after a decade of nearly steady growth) had finally eased. Consumers were therefore freed from having to carry increasingly larger denominations each year for retail transactions purposes.

For those business firms and individuals who continued to carry currency hoards resulting from the severe contraction of 1920-2I the trends in prices after 1923 provided final evidence that deflationary expectations could be safely revised. The decline in relative holdings of large bills after 1923 might also be traced to the dishoarding of currency by these groups.

${ }^{19}$ It should be noted that the overall trend in yields on financial assets was moderately downward during the period 1923 to 1929. Interest rates on high grade (Moody's AAA) corporate securities, for example, fell from 5.15 percent (in mid-1923) to 4.58 percent (in mid-1927), and then rose slightly to 4.77 percent (in mid-1929). The important point, however, is that they continued to remain quite high throughout the Twenties. 
Finally, the easing of pressures on prices between 1923 and 1929 may have had some relevance to holdings of U.S. currency by individuals and business firms in foreign countries. Postwar inflationary pressures had imposed a relatively greater burden on Europeans than they had on Americans. The relaxation of these pressures in a number of foreign countries after the mid-1920's lessened the annual declines in the value of their currencies relative to U.S. dollars and reduced incentives for converting foreign wealth into large U.S. bills. A related development-the gradual disappearance of black markets-also presumably contributed to a general decline in foreign demands for large denominations of U.S. currency during the second half of this decade.

\section{(3) The Thirties: Depression and Recovery}

The rise in relative demands for small denominations was abruptly halted in the early 1930's. The evidence for the 1930-33 period suggests that the Depression induced widespread currency hoarding (particularly between mid-1930 and mid-1932). After falling off through June, 1930, (to \$5.35) the average denomination rose rapialy through the Depression, reaching a peak (of $\$ 7.26$ ) in May, 1933. This was followed by a sudden decline in the average (to $\$ 6.36$ in December, 1934), which might suggest that rather large dishoarding of currency took place. The average was stable-to-moderately declining for the next two years, However, with the approach of World War II, the public once more began to build up its relative holdings of large bills. The average denomination showed significant gains as America moved into a new and uncertain decade. 
(a) Reaction to Crises: 1930-33

The timing of changes in the distribution of denominations in the early part of the Deprossion is of some interest, since it suggests that the trend of the late Twenties towards greater use of small bills was not arrested until sometime after June, 1930. Between mid-1929 and mid1930 total holdings of small denominations rose from 85.0 to 87.4 percent of the total currency stock, while the average denomination continued its post-1923 decline (to $\$ 5.35$, its lowest point for any year between 1914 and 1965). This might point to the continuing influence of factors considered in the previous section.

The distribution of denominations changed rather abruptly over the next three years, as individuals and businesses increased their relative holdings of large bills. The volume of small denominations fell from 87.4 to 70.5 percent of the total currency stock between June, 1930, and February, 1933 (a level almost as low as that registered during the final years of World War I). Relative demands for most small denominations (non-gold coin and $\$ 1, \$ 5$, and $\$ 10$ bills) fell off sharply, particularly during 1931 and 1932. Holdings of \$20 bills remained fairly stable between 1930 and 1933, while demands for gold coin rose rapidly. ${ }^{20}$ A number of possible explanations for these changes are examined below.

20 The largest increase in relative holdings of gold coin occurred between January and February of 1933 (from 3.6 to 4.5 percent of the total currency stock). Between February and March of 1933 there was a very . sizable decline in these holdings (to 1.3 percent of the currency stock), reflecting public reaction to the official prohibition of the use of gold coin. Holdings continued to fall off through December, 1.933, at which time they constituted only 0.4 percent of the currency stock. 


\section{(i) Retail Trade}

The Depression cut sharply into the volume of those retail transactions with which we associate small currency denominations. From 1929 to 1933 total sales at non-durable goods stores fell from $\$ 32.8$ billion to $\$ 19.1$ billion, with particularly sizable declines occurring in sales at food, apparel and general merchandise stores. Lessened needs for small bills may reflect the reduction in household purchases at these stores.

\section{(ii) Currency Substitutes}

The vigorous expansion in the volume of substitutes for currency begun in the 1920's was abruptly halted early in the Depression. As can be seen in Table 4, the subsequent decline in holdings of these assets between 1930 and 1933 was substantial. The largest part of the decline is undoubtedly associated with the depletion of total national wealth during these years. However, since the stock of currency increased over the same period (with the largest relative gains occurring in the large bills category), there is reason to believe that part of the decline in holdings of non-currency assets resulted from crisis-induced transfers of wealth from non-currency to currency forms.

Holdings of certain types of currency substitutes were immediately affected. The large scale dumping of corporate equities late in October, 1929, is an example. The uncertainties generated by the Stock Market Crash soon affected the demand for other financial assets and precipitated a general decline in their yields. ${ }^{21}$ Successive waves of business failures

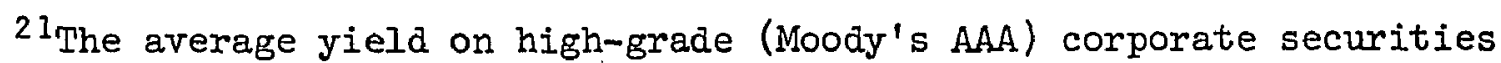
fell from 4.76 percent (in November, 1929) to 4.40 percent (in August, 1931). A sudden rise boosted it to 5.41 percent by June, 1932 . The downward trend was resumed the following month and continued through January, 1933 (when it stiood at 4.44 percent). 
seriously impaired public confidence in the ability of businesses to honor their bond issues, a factor which merely increased their inability to refund them.

Commercial banks fared no better. The Depression cut sharply into their deposits. Faced with a general decline in their earning assets, many banks were forced to lower the average interest rates paid on deposits. Their attempts at attracting customers were greatly frustrated by successive waves of bank failures and the deterioration of public confidence in the ability of banks to make payments. From 659 in 1929, the number of suspensions rose sharply (to 1,350 in 1930 and 2,293 in 1931), fell off slightly (to 1,453 in 1932 ), and then rose again to a record nigh (of 4,000 in 1933).

The evidence for the early 1930's suggests several possibilities. First, it might be reasonably assumed that banks which were not members of the Federal Reserve may have substituted larger-valued notes for deposits as reserves. Between mid-1929 and mid-193.l total bank holdings of currency rose sharply (from $\$ 770$ to $\$ 851$ million), following a halfdecade of steady decline. Part of the increase may reflect large-scale currency withdrawals by many banks from their correspondent bank accounts (and subsequent attempts by these correspondents to replenish their own currency stocks). Since interbank transfers of currency were presumably quite large at this time, one would expect to observe a rise in the relative circulation of higher-valued notes. Some small part of the increased bank holdings of currency may have consisted of the largest bills $(\$ 5,000$ and $\$ 10,000)$ which could be 
shown to customers as dramatic "proof" of bank solvency. ${ }^{22}$ Increased bank demands for larger bills may therefore have supplemented the rising demands for such bills by those non-bank business firms and households which, as noted earlier, converted their interest-earning assets into (relatively safer) currency assets. As a possible consequence, the average denomination of currency rose sharply.

\section{(iii) Price Deflation}

The decline in public confidence in the ability of businesses to honor claims on their assets is especially notable because it coincided with a rapid reduction in the general level of prices. Following a decade of relative price stability, the first third of the 1930's produced one of the sharpest price deflations in U.S. history. From a level of 58.6 in mid-1930, the consumer price index dropped to 52.7 (mid-1931), 47.5 (mid-1932), and 44.3 (mid-1933). While the price decline may have reduced the need for large bills (through decreasing the value of the average currency transaction), it may also have led to expectations of further price decline and thus have encouraged individuals and businesses

22 Friedman and Schwartz divide the Depression into three subperiods each of which was characterized by a rash of bank failures. The approximate dates of these banking crises are October, 1930, to January, 1931 (first crisis); March, 1931, to June, 1932 (second crises); and December, 1932, to March, 1933. ' [See Friedman and Schwartz, op. cit., pp. 308-32]. It is worth noting that these periods correspond with the greatest periods of decline in relative holdings of small bills. During the first crisis total holdings of small denominations fell from 87.4 to 84.2 percent of the currency stock, followed by a reduction from 83.6 to 73.3 percent (during the second crisis), and from 74.9 to 70.5 percent (during the third). This may suggest that banks did substitute large bills for deposits as reserves during the Depression and that these substitutions were substantial. This possibility was raised in written correspondence with officials at a number of clearing houses throughout the country. All agreed that such substitutions might have taken place during the Depression, but none of them were able to supply statistics in support of such a phenomenon. 
to increase their currency holdings in anticipation of a rise in the real value of these holdings. Such expectations were undoubtedly reinforced as prices continued to decline throughout the Depression. In order to protect their greatly depleted wealth (and faced with a reduction in the number of attractive forms for storing this wealth), individuals and businesses may have chosen currency--a less risky alternative--for this purpose.

(b) Recovery: $1933-37^{23}$

A rather sudden decrease in relative holdings of large bills occurred during the first half of 1933.24 After reaching a peak (of \$7.26) in May of that year, the average denomination fell off rapidy through December, 1934 (to $\$ 6.36$ ). Relative holdings of all small denominations (except $\$ 20$ bills and gold coin) showed impressive gains over the same period. Demands for $\$ 20$ bills, gold coin, and the large denominations $(\$ 50, \$ 100, \$ 500$ and $\$ 1,000)$ tended to decline between May, 1933 . and December, 1934.

23 Greater detail on changes in the distribution of denominations was made available during the early 1930's. The discussion of such changes in this and subsequent sections of the paper covers a broader range of denominations (including $\$ 50, \$ 100, \$ 500$, and $\$ 1,000$ bills) and refers to monthly (as against annual) values. Monthly values are given as of the end of the month.

${ }^{24}$ It is difficult to determine when the shift to small bills actually began. Although the average denomination began to fall off in May of 1933, the small denominations ratio began to rise somewhat earlier. Between January and February of 1933 total holdings of small denominations fell from 74.0 to 70.5 percent of the currency stock, a low point for the Depression. Over the next month, however, the small denominations ratio rose rather rapidly (to .772 ) and continued to increase each month until December, 1934. 
For the remainder of this period the average denomination fluctuated slightly ${ }^{25}$ around a moderately declining trend. In December of 1937 it stood at $\$ 6.35$. With the exception of $\$ 20$ bills and gold coin (whose relative circulation fell off greatly), all small denominations tended to increase slightly in relative circulation over this period. Relative demands for the remaining denominations were stable-to-moderately decreasing.

First, there is reason to believe that the public transferred a sizable part of its holdings of large bills to small denominations for use in retail transactions. Total sales at non-durable goods stores rose from $\$ 19.1$ million in 1933 to $\$ 24.5$ million in 1935 and $\$ 30.1$ million in 1937.

Economic recovery may also have led many individuals and businesses to transfer part of their currency holdings into other stores of wealth (particularly bank deposits and governmental securities). This inference does not appear unreasonable in light of important changes in factors which initially led the public to hoard currency. The institution of federal insurance of bank deposits (under the Banking Act of 1933) probably contributed to rebuilding public confidence in the ability of banks to honor claims on their assets. Between 1933 and 1934 the number of commercial bank suspensions fell rapidly (from 4,000 to 61), while total deposits showed impressive gains. Although holdings of private securities declined over the same period (and continued to fall off through 1937),

$25_{\mathrm{An}}$ examination of monthly changes in the average denomination reveals a distinct seasonal pattern, particularly after December, 1934 . For a discussion of seasonal patterns in the average see Chapter IV. 
holdings of government securities grew moderately. This might suggest that individuals and businesses regarded deposits and governmental securities as less risky investments after 1933 and may have led them to transfer currency "hoards" into these interest-earning assets. In addition, banks may have reduced their holdings of larger bills as the need for keeping sizable emergency reserves was lessened.

Finally, the decline in the average denomination may be associated with a revision of the deflationary expectations of the early Thirties. The downward trend in prices was reversed around mid-1933. Thereafter the consumer price index began a steady upward climb (from 44.3 in June, 1933 to 50.0 in December, 1937). It might be reasonably assumed that this encouraged those individuals and businesses which had accumulated currency during the Depression (in anticipation of a rise in the real value of their currency holdings) to shift their wealth into non-currency assets.

(4) The Second World War Period: 1938-47 A major rise in total holdings of currency (relative to those holdings associated with current transactions) occurred between January, 1938, and December, 1947. The trend in the average denomination was sharply upward: the average climbed steadily (from $\$ 6.48$ to $\$ 9.86$ ) between January, 1938 and January, 1945, was stable through 1945, and then rose once more through December, 1947 (to $\$ 10.21$ ). Total holdings of small .$\quad$ denominations fell from 76.5 to 69.4 percent of the currency stock over 
the same period. 26 Relative demands for all small denominations (except $\$ 20$ bills) showed a net decline. 27 The relative circulation of the $\$ 20$ denomination showed a large net increase between 1938 and 1947.28

Although the shift to large bills did not occur in all categories, relative holdings of certain large denominations (e.g., \$50 and $\$ 100$ bills) showed rather sizable gains. ${ }^{29}$ Holdings of the $\$ 500$ and $\$ 1,000$ denominations tended to decline during the war years, following a series of increases in the pre-war period.

It is perhaps significant that the rise in total demands for currency (relative to demands for currency for use in current transactions) was also accompanied by a substantial increase in the volume of those transactions with which we associate small currency denominations. Total sales at non-durable goods stores increased markedly each year between

${ }^{26}$ While the small denominations ratio showed a net decline between 1938 and 1947, it tended to fluctuate widely, with fairly sizable increases occurring during 1941 and 1942, and again in 1945.

${ }^{27}$ Relative holdings of coin, $\$ 1$ and $\$ 5$ bills remained fairly stable through 1939, fell off rapialy through 1945, and then were stable-tomoderately declining through 1947. Relative demands for the \$10 denomination were also stable through 1939 , but rose rapidly through 1942. Thereafter, the trend in holdings of these bills was downward.

${ }^{28}$ Relative holdings of $\$ 20$ bills fell off through 1940 , but increased quite rapidy thereafter.

29 The largest part of the increase in relative demands for these bills occurred near the end of the war and in the immediate postwar period. Demands for $\$ 50 \mathrm{bills}$ remained fairly stable through 1942 , but $\therefore$ rose gradually through 1947. Holdings of the \$100 denomination fluctuated widely: the upward trend was rather sharp and was interrupted by sudden declines in 1942 and 1945. 
1938 and $1947:^{30}$ the overall gain (from $\$ 28.6$ billion in 1938 to $\$ 83.0$ billion in 1947) is sufficiently large to suggest that small bills circulated in far greater amounts in 1947 than they did in 1938. Yet, the tendency was for a decline in the relative circulation of all small denominations (except the $\$ 20$ bill). A number of possible explanations for this development are examined below.

\section{(a) Price Behavior}

Table 5 compares movements in the average denomination and the consumer price index for the period 1938-47. Using Klein's suggestion that 1942 "represents the beginning of repressed inflation in the United States", ${ }^{11}$ we normalized both sexies in terms of values prevailing in 1942 (i.e., $1942=1.00$ for both the average denomination and consumer prices). Annuel values (as of June) were used in both cases. Column 1 of Table 5 presents the average denomination in dollar amounts. Columns 2 and 3 depict the normalized values of the average denomination and the consumer price index, respectively.

${ }^{30}$ It is of some interest that during the Depression (when total demands for currency also rose relative to demands for currency for use in current transactions) we observed a decline in total sales at non-durable goods stores.

${ }^{31}$ See Klein, op. cit., p. 371. The conditions for repressed inflation (as spelled out by Klein) are: "(I) full employment; (2) a relatively stable price index; (3) a rising stock of money; (4) a national income increasing at a slower rate than the stock of money; and (5) price, wage, demand, production, etc., controls."

- (Ibia., p. 370). Since these conditions have only rarely been present in the U.S. economy (the exception being the World War II period), we felt that the following test would be inappropriate to other periods. 
TABLE 5

A COMPARISON OF NORMALIZED VALUES OF THE AVERAGE DENOMINATION AND THE CONSUMER PRICE INDEX (AS OF JUNE, 1938-47)

\begin{tabular}{lccc}
\hline \hline Year & $\begin{array}{c}\text { Average Denomin- } \\
\text { ation (in } \$)\end{array}$ & $\begin{array}{c}\text { Average Denomin- } \\
\text { ation }(1942=1.00)\end{array}$ & $\begin{array}{c}\text { Consumer Price Index } \\
(1942=1.00)\end{array}$ \\
\hline 1938 & 6.53 & .848 & .866 \\
1939 & 6.66 & .865 & .848 \\
1940 & 6.93 & .900 & .864 \\
1941 & 7.18 & .933 & .900 \\
1942 & 7.70 & 1.000 & 1.000 \\
1943 & 8.39 & 1.090 & 1.074 \\
1944 & 9.38 & 1.218 & 1.080 \\
1945 & 9.80 & 1.273 & 1.111 \\
1946 & 10.06 & 1.307 & 1.147 \\
1947 & 10.32 & 1.341 & 1.355 \\
& - & & \\
\hline
\end{tabular}

SOURCE: Federal Reserve Bulletin (February issues, 1939-48)

A comparison of columns 2 and 3 reveals that both the average denomination and consumer prices increased each year between 1939 and 1947. One possible inference is that upward pressures on prices boosted the value of the average currency transaction. The vigorous rise in relative demands for $\$ 10$ bills (through 1942 ) and for $\$ 20$ bills (through 1947) is consistent with the observed increase in consumer prices. It is not unreasonable to assume that inflationary pressures led many individuals and businesses to substitute $\$ 10$ and $\$ 20$ bills for the smaller denominations of currency as prices rose throughout the war.

Although both the price and currency series tended to grow over the 1939-47 period, there are some interesting discrepancies between them. From 1939 to 1942 annual gains in the average denomination and consumer 
prices were roughly equal (although the average tended to grow by slightly more than prices). However, in 1942 the rate of growth in the average began to accelerate. Over the next four years the average climbed to 130.7 percent of its 1942 level, while the price index rose to only 114.7 percent of its 1942 level. The existence of such discrepancies might be interpreted in several ways. First, there is the possibility that official price estimates understate actual movements in prices after 1942. If this is true, it might be possible to associate changes in the distribution of denominations after 1942 with transactions in "unofficial", black markets. Given the higher value of the average transaction in wholesale (as against retail) black markets, the more important link between black marketing and increased preferences for large bills may be at the wholesale rather than retail level. ${ }^{32}$ This does not, however, rule out the possibility that large bills (e.g., $\$ 50$ and $\$ 100$ ) were also used to a substantial degree in retail black markets during World War II. The fact that people frequently had to pay special commissions to black market dealers, in addition to extra-high black market prices, meant that the average ceiling prices of their retail purchases were often greatly inflated. This might also help to explain the discrepancies between the average currency denomination and "official prices" following the institution of price controls in 1942.

While price behavior may serve as a fairly important explanation of denominational movements during the Second World War, a number of other considerations (discussed below) may have been equally significant. pp. 13-14.

${ }^{32}$ This distinction is suggested in Cagan, The Demand for Currency, 
(b) Tax Evasion

World War II brought an unprecedented increase in the percentage of personal income taxed. From a relatively low level of 1.47 percent (in 1939) rates tended to climb moderately (to 3.52 percent in 1942). Thereafter the trend in rates was sharply upward (to 10.7 percent in 1943 and 11.8 percent in 1945). They tended to fall off somewhat in the immediate postwar period, but still remained quite high relative to their prewar levels (e.g., personal tax collections were 11.0 percent of personal income in 1947). It might be reasonably assumed that part of the rise in relative demands for large bills during the war was due to tax evasion by those groups (i.e., professional persons and unincorporated business firms) who were in a position to escape the tax. 33

Denominational changes between 1943 and 1947 tend to support this. After 1942 relative holdings of two denominations which presumably are well-suited to tax evasion ( $\$ 50$ and $\$ 100$ bills) rose rather rapidly. 34 Holdings of the $\$ 100$ denomination reached a peak in early 1945 and declined sharply for the duration of the year. The percentage of personal income taxed also reached a peak during 1945 and declined over the following year. In addition, part of the greatly increased use of

${ }^{33}$ Cagan estimates that the amount of currency involved in the evasion of taxes by these groups in 1945 was roughly $\$ 5$ billion. (See Cagan, Determinants and Effects, p. 131).

${ }^{34}$ These bills (and the $\$ 20$ denomination) might be well-suited to tax evasion on several counts. In addition to the relatively low storage costs which they involve, $\$ 20, \$ 50$, and $\$ 100$ bills can be used in transactions without raising suspicion as to their source. This may have been particularly important towards the end of the war: in 1945 the Treasury required all banks to report transactions which involved substantial amounts of currency or large bills. Regulations of a similar nature have been issued periodically since the war. 
$\$ 20$ bills during the war might be traced to tax evasion: this denomination also registered sizable gains during the $1943-47$ period.

\section{(c) Domestic and Foreign Hoarding}

Another factor which might help to explain wartime changes in the distribution of denominations is domestic and foreign hoarding. It is well-known that the wax produced a large pent-up demand for goods both in the United States and abroad. The U.S. experience was quite different, however, since it was also associated with substantial increases in income over the war years. This suggests that many individuals and businesses had the opportunity to invest in interest-earning financial assets. As shown in Table 4, holdings of many of these assets (particularly commercial bank deposits, U.S. government securities, and corporate equities) grew substantially over the $1939-45$ period. However, it might be reasonably assumed that part of the increase in income was stored in the form of currency. Interest rates tended to remain fairly low throughout the war years, which may have dissuaded certain individuals and businesses from switching to non-currency financial assets. In addition, recollections of another, not-so-distant crisis period--the Depression-may have led many individuals and businesses to take a somewhat skeptical view of war-induced prosperity and the ability of business firms to honor claims on their assets. Banks may also have contributed to the increased use of large bills by building up emergency reserves in order to protect themselves against possible currency withdrawals in the future.

Finally, it is not unreasonable to assume that the rise in relative demands for $\$ 20, \$ 50$, and $\$ 100$ bills in the immediate postwar period 
might be associated with a revision of price expectations. Holding to the widespread belief that what goes up must come dow, certain individuals and businesses may have expected that the severe inflationary pressures of the war years would be followed by a rather large deflation. Expectations of price declines after 1945 may have led them to increase their currency holdings in anticipation of a rise in the real value of these holdings.

Foreign businesses and individuals may have been influenced by similar considerations. An important difference is that the war greatly depleted their wealth and reduced the number of attractive forms in which they could hold it. There can be little doubt that U.S. currency represented the safest refuge for their funds. Foreign demands for U.S. currency during the war may have contributed to the rise in large bills, although this factor has been shown to be of less quantitative importance than those previously considered. 35 However, foreign demands may help to explain the very large gains in the circulation of $\$ 500$ and $\$ 1,000$ bills in the prewar period.

(5) The Postwar Period: 1948-65

Not unexpectedly, the denominational evidence for the postwar period suggests a rise in the demand for currency for use in current transactions relative to the total demand for currency. From a peak of $\$ 10.42$ in February, 1948, the average denomination declined gradually for five years (to $\$ 9.75$ in December, 1952), rose moderately through early 1954 (to \$9.94

35 The Federal Reserve Bank of New York estimates that foreign demands for U.S. currency to hoard during the $1940-45$ period account at most for about one-tenth of the total increase in currency. (See Monthly Review, Federal Reserve Bank of New York, July 1948, p. 75). Part of the increase may be traced to the great rise in the number of U.S. troops stationed abroad. 
in February of that year), and then fell off once more (reaching a low point of $\$ 9.14$ in December, 1962). For the duration of the sample period the average rose moderately (to $\$ 9.28$ in December, 1965).

Over the same period total holdings of small denominations showed a moderate secular increase (from 68.9 to 71.0 percent of the total currency stock). The shift to small denominations did not occur in all categories. Relative holdings of $\$ 10$ bills fell off rather sharply over the 1948-65 period, while those of $\$ 5$ bills showed a more moderate decline. Demands for coin, on the other hand, increased rather rapidly, while demands for the $\$ 1$ and $\$ 20$ denominations tended to rise gradually. Relative holdings of most large denominations were stable-to-moderately declining. An exception is the $\$ 100$ bill, the relative circulation of which rose quite sharply during the 1948-65 period.

The evidence suggests that the post-World War II rise in transactions demands for currency relative to total demands for currency was noticeably more moderate than the increases following either World War I or the Depression. Unlike the earlier periods, the post-World War II years were not associated with a rapid and sizable decline in the average denomination. At first glance this appears rather surprising in light of the large annual gains in sales of non-durable goods stores (which climbed from $\$ 88.6$ billion in 1948 to $\$ 190.2$ billion in 1965). The fact that relative holdings of small denominations did not grow apace with these "small ticket" sales (and, in the case of $\$ 5$ and $\$ 10$ bills, declined considerably) may be traced to a number of postwar developments, described below. 
(a) Domestic and Foreign Hoarding

Frequent reference ${ }^{36}$ has been made to the fact that on a per capita basis postwar currency holdings seem out of proportion to individual needs for currency for current transactions.37 The fact that these holdings consist of many large bills may suggest that a significant part of them represent hoards carried over. from World War II. While the per capita currency statistic may not be as meaningful as certain writers imply, 38 it does raise the possibility that the currency holdings of certain individuals and businesses continued to reflect influences initiated during the war.

Tax evasion is frequently cited as an important causative factor. Although the percentage of personal income taxed fell off somewhat toward the end of the Forties (from 9.77 percent in 1948 to 8.78 percent in 1950), it rose suddenly during the Korean War (to 12.30 percent in 1952) and tended to remain near this level through 1965. The timing of

. ${ }^{36}$ See, for example, Kaufman, op. cit., pp. 10-12; Federal Reserve Bank of Richmond, Monthly Review, October, 1965, pp. 5-6; Federal Reserve Bank of Chicago, Business Conditions, August, 1965, pp. 13-16.

${ }^{37}$ Between 1918 and 1939 per capita currency holdings fluctuated between $\$ 27$ and $\$ 46$. World War II brought a sudden and unprecedented rise in these holdings (to a peak of $\$ 190$ in mid-1945). From 1945 to 1960 they declined moderately (to $\$ 157$ ) and then resumed their upward course during the first half of the Sixties (to \$175 in mid-1965).

${ }^{38}$ In a recent study the Federal Reserve Bank of Boston suggests that the per capita currency statistic may reflect a tendency for a very small proportion of the total population (possibly concentrated in larger U.S. cities) to accumulate substantial hoards. The possibility that these individuals continued to hold currency after the war (while those who normally do not hoard currency--but did so during the war--may have dishoarded) might explain the failure of the per capita statistic to return to its prewar level. See Federal Reserve Bank of Boston, New England Business Review, December, 1965, pp. 2-10. 
movements in the average denomination and the percentage of personal income taxed does not support as close a relationship between the two variables as might be expected, given the very high levels of the tax. (The sharp rise in the percentage of personal income taxed between 1950 and 1951 , for example, coincided with a moderate decline in the average, which continued to fall off throughout the decade). It may be, however, that the high postwar tax rates had a more generalized effect on currency holdings. One possibility is that large scale tax evasion took place in the late Forties (when Federal efforts aimed at discouraging such activities were presumably conducted on a smaller scale than they were in the Fifties and early Sixties). A reasonable assumption is that the rise in relative holdings of $\$ 100$ bills (most of which occurred prior to 1950 ) is associated with this. Throughout the Fifties the relative circulation of this denomination remained fairly stable (perhaps reflecting a growing awareness of Federal attempts at tracking down tax evaders). The sudden rise in holdings of $\$ 100$ bills after 1961 does not appear to be consistent with this argument (particularly in light of the highly publicized program of using computers to check the accuracy of tax returns), but this may be due to other factors.

An additional possibility is that the relatively high postwar levels of the average denomination may be associated with foreign hoarding. While the postwar period may have been accompanied by generally rising confidence in foreign, currencies (particularly those of Western Europe), many new countries have come into existence, and nearly all of them have 
estailished their own currencies. ${ }^{39}$ It might be reasonably assumed that their attempts at developing stable currencies have been frustrated by domestic hoarding of U.S. bills. Given the general disparities in the distribution of wealth in such countries, such hoards would most likely to be concentrated in the higher income categories and would take the form of large bills.

\section{(b) Price Behavior}

The failure of the average denomination to return to pre-war levels may also be explained in terms of continuing pressures on consumer prices.40 Following a slight decline between 1948 and 1950, the consumer price index rose steadily throughout the postwar period. Although annual upward pressures on prices were presumably far greater during the war years, the moderate secular rise in prices between 1950 and 1965 may have great relevance to currency behavior. By implication, it suggests that the value of the average transaction in currency in 1965 was far in excess of its 1948 level. This might help to explain the tendency for relative holdings of $\$ 10$ bills to decline (and of $\$ 20$ bills to rise) over the postwar period. It might be reasonably assumed that inflationary pressures led many individuals and businesses to substitute $\$ 20$ for $\$ 10$ denominations as prices continued to rise throughout the Fifties and early Sixties.

While relative demands for the larger bills remained quite high during the postwar period (possibly due to the influence of prices and

${ }^{39}$ See Federal Reserve Bank of Richmond, op. cit., p. 7 .

40 Between January, 1948, and December, 1965, the consumer price index rose from 82.6 to 111.0 . 
taxes), they did fall off slightly. A number of possible explanations for this development are discussed below.

\section{(c) Currency Substitutes}

Part of the decline in these holdings may reflect a transfer of wartime currency hoards to interest-earning assets. Interest rates showed a general secular rise over the period, particularly after the midFifties. 41 From 1955 to 1961 the average rate paid on time deposit accounts by member banks more than doubled (from 1.36 to 2.73 percent), while dividends on savings and loan rates also showed substantial gains (from 2.9 to 3.9 percent). ${ }^{42}$ The introduction of such new credit instruments as time certificates of deposit may also have contributed to the decline in relative holdings of large bills. These developments may be particularly relevant with regard to the observed decline in relative holdings of the very large denominations of U.S. currency (\$500 and $\$ 1,000)$ over the 1948-65 period.

(d) Consumer Credit

An additional possibility is that the rise in transactions demands for currency relative to total demands for currency may be linked to the greatly increased use of consumer installment credit facilities in the postwar period. The per capita volume of consumer instaliment credit showed a moderate secular increase between 1914 and 1945 (when it stood at $\$ 18.50)$. A sudden expansion of credit buying in the immediate postwar

${ }^{41}$ See Federal Reserve Bank of Richmond, op. cit., p. 7 .

${ }^{42}$ Interest payable on non-bank financial assets also tended to show rather large gains over the latter part of the 1948-65 period. Interest rates on high-grade (Moody's AAA) corporate securities rose from 3.05 to 4.46 percent between mid-1955 and mid-1965. 
period boosted the credit statistic to $\$ 96.80$ (at mid-1950). Possibly as a result of the controls which were imposed upon consumer credit during the Korean War, the gains in the early Fifties were moderate. This was followed by rather striking increases through 1965 (at which time the per capita volume of consumer installment credit stood at $\$ 354.00)$.

For reasons noted in Chapter II, generalizations about the creditcurrency relationship are difficult. The observed decline in relative holdings of $\$ 5$ and $\$ 10$ bills over the postwar period may be partly due to a substantial lumping of payments for small purchases (against which individuals might otherwise hold $\$ 5$ and $\$ 10$ bills were these credit facilities not made available). A related development--the growth of creảit cards ${ }^{43}$--may have contributed to this, since these cards may be reasonably good substitutes for the $\$ 5$ and $\$ 10$ denominations. However, the fact that individuals may also have used these credit facilities to make more high-valued purchases (against which large bills might otherwise be held for payment) complicates matters. The observed decrease in relative holdings of bills in excess of $\$ 100$ over the postwar period may suggest that this latter consideration was quite important (although it is not possible to determine its true importance without additional information on the use of checks in making such payments). For these reasons generalizations about the relationship between postwar credit developments and changes in the distribution of denominations are highly speculative.

${ }^{43}$ See Federal Reserve Bank of Richmond, op. cit., p. 10. 
(e) Factors Relating to the Increased Use of Coin

Finally, it is quite possible that rising transactions demands for currency over the postwar period were associated with the phenomenal growth in the volume of needs for coin, particularly during the first half of the $1960^{\prime} \mathrm{s}^{4}$ A number of developments (including the greatly increased use of coin-operated vending machines, the sharp rise in the percentage of the population which presumably holds a very large share of total coin, 45 and the increase in the number of bons fide coin collectors and dealers) might have contributed to this. In adaition, it is possible that part of the increased use of coin may be traced to " " speculation on the price of silver rising above the melting price. Although these explanations may appear to be somewhat conjectural (since little is known about the distribution of coin), they appear to have gained increasing acceptance in recent years.

$$
* * * * *
$$

In sum: the historical evidence suggests that rather striking changes occurred in the distribution of U.S. currency denominations over the period 1914-65. Perhaps the most interesting find of this brief historical survey is the tendency for periods of economic and political crisis (e.g., 1914-18, 1930-33, and 1938-47) to be associated with massive shifts to the larger currency denominations. We have

\footnotetext{
${ }^{4}$ See Federal Reserve Bank of Chicago, op. cit., p. 16.

45 See Federal Reserve Bank of Richmond, op. cit., p. 6. The
} growth in the number of teenagers may be particularly important. From 1955 to 1960 the number of persons in the 15-19 age group rose by 20.3 percent; between 1960 and 1965 the estimated gain in this group was 26.1 percent. 
attributed this to a number of factors, including upward pressures on prices, higher taxation of personal income, and the emergence of black markets (during wartime), and the decline in public confidence in the ability of businesses to honor claims on their assets (during the Great Depression). During more "normal" periods, we observed a large-scale dishoarding of large bills, which might suggest that individuals and businesses were under less pressure to hold the higher denominations at such times. The shift away from large bills was far more pronounced during the period 1920-29 than it was between 1948 and 1965. This might indicate that such considerations as rising prices, tax evasion, and foreign hoarding continued to play an important role in maintaining the higher demands for large bills in the post-World War II period.

In the following chapter regression estimates of the demand for currency denominations are developed to test for the various secular influences noted earlier. 
CHAPTER III

\section{Estimation of Secular Demand Functions for}

\section{Currency Denominations, 1923-651}

In Chaptex II the demand for currency denominations was presented as a conventional demand relationship, incorporating the prices of . substitutes, income (or wealth) and tastes. In the present chapter we attempt to give this relationship empirical content. The statistical evidence should, as a minimum requirement, enable us to determine the following:

(1) Are the relationships between the average denomination of currency and the variables upon which-it.is said the depend statistically significant and in the expected directions?

I In the following we have employed the "stepwise" regression technique. This method has two important characteristics: (1) it shows all intermediate steps in the process of deriving a complete multiple regression equation, and (2) it introduces variables in the order of their ability to improve "goodness of fit". The variables are entered one at a time, which yields the following intermediate equations:

$$
\begin{aligned}
& y=\beta_{0}+\beta_{1} x_{1} \\
& y=\beta_{0}+\beta_{1} x_{1}+\beta_{2} x_{2} \\
& y=\beta_{0}+\beta_{1} x_{1}+\beta_{2} x_{2}+\beta_{3} x_{3},
\end{aligned}
$$

where $y$ is the denominational statistic, $x_{1}, x_{2} \ldots x_{n}$ the monthly dummy variables and $\beta_{0}, \beta_{I} \ldots \beta_{N}$ ordinary least-squares regression coefficients. At the time each variable is entered the calculation provides valuable statistical information, including the coefficient of determination $\left(r^{2}\right)$, the appropriate regression coefficients, and the " $t$ " statistics. For a detailed discussion of this process see M. A. Efroymson, "Multiple Regression Analysis," in A. Ralston and H. Wilf (eds.), Mathematical Methods for Digital Computers (New York: John Wiley \& Sons, 1960), pp. 191-203. 
(2) Can the supposedly strong influence of "crisis" factors on the average denomination which is suggested by the historical evidence be statistically demonstrated?

(3) Do the statistical findings point to the existence of a lag in the adjustment of denominational holdings?

(4) Is there evidence to suggest that the distribution of denominations of currency displays a seașonal pattern, in accordance with our historical observations?

The first three matters are tiken up in the present chapter. The fourth is discussed in Chapter IV.

Previous studies of currency behavior can be of some value in the development of a statistical design. The point of emphasis in the present study differs somewhat from that of these studies, since it is the size rather than the denominational composition of currency holdings which they generally examine. However, many of the same variables which have been used may usefully be employed in the present study. The work of Cagan ${ }^{2}$

${ }^{2}$ Cagan specifies the ratio of currency to money (broadly defined) as the dependent variable. His explanatory variables include (I) expected interest on total deposits (adjusted prior to 1934 for losses on deposits), (2) real permanent per capita income, and (3) the percent of personal income taxed. The currency ratio is found to vary inversely with income and interest rates and directly with the percentage of personal income taxed. Together these three variables are shown to explain nearly 90 percent of the variance in the currency ratio between 1919 and 1955. (See Phillip Cagan, The Demand for Currency, p. 20).

Cagan's regression was rerun to test its applicability to the distribution of denominations. The average denomination of currency was used as the dependent variable, while the explanatory variables were the same as those employed by Cagan. The number of observations was reduced slightly, due to problems encountered in obtaining data: Cagan's estimates cover the period 1919 to 1955, while the present author's extend from 1931 to 1965 . Nevertheless, the results are strikingly similar. The 
and de Leeuw, ${ }^{3}$ for example, suggests that regression equations for currency should, as a minimum requirement, include one interest rate and one price or income variable. In addition, the historical evidence suggests that regression estimates should include one or more variables which are perticularly sensitive indicators of crisis pressures on the distribution of denominations. The collection of variables considered for inclusion in estimating equations is discussed below.

average denomination was found to vary inversely with interest rates and directly with the percentage of personal income taxed. The coefficient of determination $\left(r^{2}\right)$ was .928 and all variables were found to be significant at the .05 level of significance. An important difference between these results and those of Cagan is that income was shown to vary directly with the currency variable, suggesting that the public increases its holdings of large bills with a growth in income. For reasons noted in Chapter II, the precise relationship between the amount of income received and the average denomination is difficult to establish since rising income may serve as a "proxy" for a wide variety of other developments which alter the way in which payments are made and wealth is stored. For this reason, it was decided to use some other measure of income change (such as changes in the level of prices or the volume of consumer credit) in further regressions.

${ }^{3}$ De Leeuw's studies of currency behavior fall into two general categories. In 1964 he showed that changes in currency (normalized in terms of the level of permanent gross national product) were inversely related to rates on long-term Treasury bonds and commercial bank time deposits, and deflated levels of lagged currency, household investment, and business investment. Also, they were directly related to the deflated levels of disposable personal income. These variables were shown to explain as much as 66 percent of the variance in the dependent variable. (See Frank de Leeuw, A Condensed Model of Financial Behavior. [Unpublished study, U.S. Board of Governors of the Federal Reserve System, July, 1964], pp. 27-28).

In a more recent study, de Leeuw related real per capita currency to interest rates, wealth, income, deviation from mean income, and lagged currency. Variables were specified in terms of levels at one time, and first differences at another. (See Frank de Leeuw, The Demand for Money: Speed of Adjustment, Interest Rates, and Wealth, Staff Economic Studies [Washington: U.S. Board of Governors of the Federal Reserve System, 1965]). 


\section{(A) Measurement of the Variables}

\section{(I) Dependent Variable}

Published statistics on "small" denominations of currency actually in circulation are available on an annual basis since October, $1930 .^{4}$ Data on large denominations are not available until May, 1933. Since that date statistics on both small and large denominations are available on a monthly basis. Fairly reliable annual estimates of the circulation of small denominations (as of June) can be derived by extrapolating the post-1930 small bills information back to $1914 .^{5}$ Similar extrapolations of monthly statistics on currency denominations do not yield meaningful results, which suggests that regressions involving monthly data must be confined to the period beginning May, 1933.

As demonstrated in the previous chapter, the average denomination of currency is a useful conceptual device for tracing changes in the distribution of currency denominations over time. Unless otherwise noted, the average denomination is used as the dependent variable in all regression equations.

A difficulty in using this series is that it is developed from highly aggregative statistics which embrace several economic sectors. ${ }^{6}$

4See U.S. Board of Governors of the Federal Reserve System, Banking and Monetary Statistics (1943), pp. 415-16 for monthly denominational statistics for the period October, 1930 to December, 1941. Denominational data for the period January, 1942 to December, 1965 is taken from U.S. Board of Governors of the Federal Reserve System, Federal Reserve Bulletin (February issues, 1943-66).

${ }^{5}$ See Appendix A, p. 129.

${ }^{6}$ As noted earlier, published statistics on currency denominations include (a) all holdings by U.S. households and business firms; (b) all bank vault cash; and (c) total currency lost, destroyed or carried abroad. 
Published estimates of currency holdings by ownership group suggest that . households account for between 80 and 85 percent of total currency holdings. ${ }^{7}$ In addition, unincorporated business firms, which might reasonably be assumed to encompass the large majority of small businesses, account for 57 percent of total business currency holdings. ${ }^{8}$ Hence, there is good reason to expect that movements in the average denomination (computed from highly aggregative currency statistics) closely approximate movements in the average denomination of currency demanded by households and small businesses.

\section{(2) Explanatory Variables}

With few exceptions, statistical estimates of our explanatory variables are only available after the early 1920's on an annual basis and after the post-World War II period on a monthly basis. The collection of variables considered for inclusion in regression estimates is discussed below. (a) Interest Yields on Currency Substitutes

Since households and businesses can hold their wealth in the form of a large variety of non-currency financial assets, it is possible to identify many "substitute prices" for currency. Cagan ${ }^{9}$ suggests that as a medium of exchange the closest substitute for currency is a checking

7 In 1955 the U.S: Board of Governors published such findings for the period 1939 to 1954. See "Selected Iiquid Asset Holdings of Individuals and Businesses," Federal Reserve Bulletin, XII (July, 1955), pp. $749-50$.

${ }^{8}$ Friedman has shown that "the demand for money on the part of business enterprises can be regarded as expressed by a function of the same kind" (with the same variables) as the demands for money by other "wealth-owning units." (See Friedman, op. cit., p. 13).

${ }^{9}$ See Cagan, Determinants and Effects, p. 119. 
account, while as a "store of wealth (it is) probably a savings deposit."10 Unfortunately, available estimates of average interest paid on bank deposits do not have the coverage which our estimating equations require: that is, there is no series on deposit yields which is available on either an annuel basis since 1914 or a monthly basis aince May, 1933. Many other series on interest yields are available, including rates paid on Treasury bills, commercial paper and corporate bonds. Of those surveyed, the last comes closest to meeting the requirements of the regression equations. Average interest rates payable on high-grade (Moody's AAA) corporate securities are published on a monthly basis as early as 1919.11

The use of this series might be questioned on the grounäs that variation in such rates may not be directly relevant to the decisions of those who hold the largest share of currency (i.e., households). It must be emphasized, however, that this series is used as a proxy for general movements in yields on non-currency financial assets. Its value is constrained by the extent to which movements in the series parallel movements in other interest rates (such as those paid on bank deposits) which might be more directly relevant to decisions to hold particular bills.

10 Ideally, it would be possible to incorporate some measure of yields on each of these two types of deposits in regression equations. A problem is that for the pre-1927 period no breakdown of rates on time and demand deposits is available. The prohibition of the payment of interest on demand deposits in 1933 introduces a complicating element.

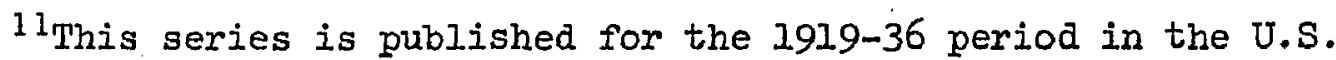
Department of Commerce, Survey of Current Business, November, 1937. Date for the 1937-65 period is taken from November issues of the same publication. 


\section{(b) Prices}

The Bureau of Labor Statistics' Consumer Price Index (1957-59 = 100.0) was selected as the price variable. Among the price indexes surveyed, 12 the Consumer Price Index seemed most directly relevant to household decisions. It is published on a monthly basis as early as 1913.13

\section{(c) Consumer Credit}

Federal Reserve estimates of the total dollar volume of consumer installment credit outstanding were used as the credit variable. ${ }^{14}$ This series includes all short and intermediate-term credit extended to consumers which is scheduled to be repaid in two or more installments. It is available on an annual basis since 1921. The series was normalized for population changes by dividing each value by the total resident U.S. population. I5

12 These included various official price estimates (the Consumer and Wholesale Price Indexes) and a number of privately compiled series (including Kuznets' implicit price index and Friedman's estimates of "permanent prices"). The Wholesale Price Index was rejected on the grounds that it seemed more relevant to business than household decisions. The Kuznets and Friedman series do not have the coverage required by the regression equations, since they are not available on a monthly basis.

13 This series appears in U.S. Department of Labor, Bureau of Labor Statistics, Changes in Cost of Iiving in Large Cities in the United States, 1913-41. (Bul.1etin 699, 1941) and U.S. Department of Commerce, February issues, 1940-66, op. cit.

14 These statistics appear in U.S. Board of Governors of the Federal Reserve System, Supplement \#16 to Banking and Monetary Statistics (1965).

15 population statistics appear in the U.S. Department of Commerce, Bureau of the Census, Statistical Abstrect of the United States, 1966 (87th Edition), p. 5 . 


\section{(d) Personal Income Taxes}

A series suggested by Phillip Cagan was used as the tax variable. This series represents the ratio of personal income taxes (collected by federal, state, and local governments) to total personal income. It is available on an annual basis since 1919.16

(e) Deposit-Money Ratio

Estimates compiled by Milton Friedman and Anna Schwartz were used for the deposit variable. They represent the total dollar volume of demand and time deposits (adjusted) in commercial banks divided by the sum of (1) currency held by the public (including banks), (2) total commercial bank deposits (adjusted), and (3) the total deposits (adjusted) of mutual savings banks and the postal savings system. ${ }^{17}$

The choice of a rather broad definition of "deposits" and the "money . stock" may have certain advantages. The present study treats currency not only as a medium of exchange, but also as a means for storing wealth prior to the making of payments. The numerator of the deposit-money ratio includes what may be regarded as the closest substitutes for currency with regard to these two functions. A fall in the demand for these substitutes (relative to the total demand for money, broadly defined) might indicate a decline in public confidence in the ability of banks to make payments.

${ }^{16}$ See Cagan, The Demand for Currency, pp. 31-32. Cagan uses Department of Commerce data for the period 1929-55. Prior to 1929, unofficial estimates are used. The Cagan series was extended to 1965 using U.S. Department of Commerce, ibid., 1956-66 issues.

${ }^{17}$ See Friedman and Schwartz, op. cit., pp. 708-22. The series was updated using the U.S. Board of Governors of the Federal Reserve System, Federal Reserve Bulletin (February issues, 1961-66). 
Since the deposit-money ratio is equal to one minus the currency-money ratio, crisis-induced deposit withdrawals would boost the latter magnitude, other things being equal. Under such conditions one might also expect to observe a rise in the average currency denomination, as non-member banks build up emergency reserves and individuals transfer deposits to (less risky) currency hoards.

\section{(f) Bank Suspensions}

The Federal Deposit Insurance Corporation has compiled estimates of the number of commercial bank suspensions annually since 1921.18 Since currency behavior might reasonably be assumed to reflect an adjustment to both past and present changes in the number of suspensions, a five-year moving average of these suspensions is used in the present study.

\section{(g) Wartime Crises}

Wartime uncertainties might be represented in proxy by using the relative size of the military population or zero-one variables. Both measures were used in regression estimates. The former approach might, for example, express the total number of military personnel on active duty as a percentage of the total resident U.S. population. This information is available on an annual basis since 1917.19 The latter approach might involve assigning a value of "zero" to non-crisis periods and "one" to crisis periods. A difficulty in this approach is that it is

18These statistics are published in Friedman and Schwartz, op. cit., pp. 438-40. They were updated using data from the Annual Reports of the Federal Deposit Insurance Corporation, 1961-66.

${ }^{19}$ See U.S. Department of Commerce, loc. cit. 
less precise and may involve incorrect judgments as to the timing of crisis periods.

(h) other Variables

A large number of other variables were considered for possible inclusion in regression estimates. A fully complete analysis of denominational demands would account for the relationship between the average denomination and such factors as the distribution of income, the mobility of the population, the degree of urbanization and other factors which students of money have shown to be relevant to the size of currency holdings. After careful consideration of these factors we decided to exclude them from regression estimates. Statistics on changes in income distribution, for example, are not complete enough to be included in regression estimates extending back to the early Twenties. 20 Furthermore, the theoretical basis for this variable is difficult to determine, since (as was noted in Chapter I) it is first necessary to establish whether or not the currency holdings of low-income individuals are primarily related to current consumption or to "hoards". Similar difficulties exist with regard to the "mobility" and urbanization variables. Future research into the matter of denominational demands might profitably be directed to a consideration of these variables.

20 The Department of Commerce has published estimates of changes in income distribution by income class which extend back as early as 1869 . Annual Commerce data on income distribution is generally not available before the post-World War II period. (See U.S. Department of Commerce, Bureau of the Census, Historical Statistics, pp. 140-41, 163-67). An exception is a series on "percent shares of total income received by the top one percent and five percent of the total population, 1913-48" (see ibid., p. 167). Unfortunately, this series was uncovered too late in our research to be included in regression estimates. 
(B) Interpretation of Results Using Annual Data, 1923-65

\section{(1) General Techniques}

Least squares estimates of the demand for denominations of U.S. currency using annual data, 1923-65, are shown in Table 6. Each of the equations employs the average denomination as the dependent variable. All variables are expressed as levels. The coefficients and their standard errors (in parentheses) are shown in columns 2-7. Columns 8-10 depict the mean, standard error of estimate, and coefficient of determination (adjusted for degrees of freedom), respectively. The equations are shown to explain between 61.1 and 91.4 percent of the variation in the average denomination. The standard errors of estimate fall within the range of $\$ 1.01$ to $\$ 0.51$, or between 12.2 and 6.1 percent of the average denomination. With a single exception all variables are statistically significant. ${ }^{21}$

Each of the equations might be regarded as a separate hypothesis. Equation (I) employs a single independent variable (the consumer price index) and tests for the operation of a simple quantity-theory type mechanism in denominational demands. This hypothesis is rejected on the grounds that the explanatory power of the equation (as measured by the coefficient of determination) is insufficient to justify the operation of such a mechanism in its more naive form: while shown to be significant to the distribution of denominations, the price level is but one of a number of factors which influence denominational demands. The remaining equations introduce these other factors. Equations (2)-(3) add interest

${ }^{21} \mathrm{~A}$ coefficient is shown to be statistically significant if its value is at least twice the size of its standard error. 
TABLE 6

ESTIMATES OF THE DEMAND FOR DENOMINATIONS OF CURRENCY, USING LEVELS OF THE DATA, 1923-65*

(Annual Values)

\begin{tabular}{|c|c|c|c|c|c|c|c|c|c|c|c|}
\hline & CPI & $I_{28,8}$ & CRDPOP & PYTX & MILPOP & DEPMON & BKSUS & 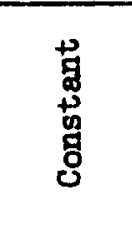 & 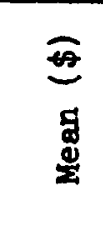 & 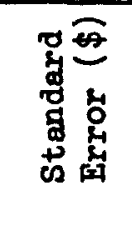 & 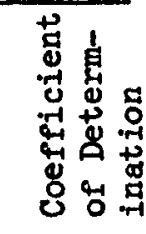 \\
\hline Equation 1 & $\begin{array}{l}.055 \\
(.007)\end{array}$ & -- & $-\infty$ & - & - & $-m$ & -- & 4.22 & 8.29 & 1.010 & .611 \\
\hline Equation 2 & $\begin{array}{l}.056 \\
(.005)\end{array}$ & $\begin{array}{l}-.866 \\
(.128)\end{array}$ & - & -- & -- & - & - & 7.34 & 8.29 & .693 & .817 \\
\hline Equation 3 & $\begin{array}{l}.085 \\
(.012)\end{array}$ & $\begin{array}{l}-.740 \\
(.128)\end{array}$ & $\begin{array}{l}-.007 \\
(.003)\end{array}$ & - & -- & - & -- & 5.42 & 8.29 & .643 & .842 \\
\hline Equation 4 & $\begin{array}{l}.038 \\
(.015)\end{array}$ & $\begin{array}{l}-.334 \\
(.141)\end{array}$ & $\begin{array}{l}-.006 \\
(.002)\end{array}$ & $\begin{array}{l}.210 \\
(.048)\end{array}$ & -- & - & - & 5.85 & 8.29 & .531 & .893 \\
\hline Equation 5 & $(.081)$ & $\begin{array}{l}-.613 \\
(.132)\end{array}$ & -.006 & -- & $\begin{array}{l}.127 \\
(.054)\end{array}$ & -- & -- & 5.01 & 8.29 & .608 & .859 \\
\hline Equation 6 & $\begin{array}{l}.105 \\
(.011)\end{array}$ & $\begin{array}{l}-.551 \\
(.114)\end{array}$ & $\begin{array}{l}-.010 \\
(.002)\end{array}$ & -- & -- & $\begin{array}{l}-.129 \\
(.030)\end{array}$ & -- & 12.90 & 8.29 & .533 & .892 \\
\hline Equation 7 & $\begin{array}{l}.088 \\
(.013)\end{array}$ & $\begin{array}{l}-.779 \\
(.157)\end{array}$ & $\begin{array}{l}-.007 \\
(.003)\end{array}$ & -- & -- & - & $(.0001)$ & 5.33 & 8.29 & .650 & .839 \\
\hline Equation 8 & $\begin{array}{l}.065 \\
(.016)\end{array}$ & $\begin{array}{l}-.309 \\
(.126)\end{array}$ & $\frac{-.008}{(.002)}$ & $\begin{array}{l}.152 \\
(.047)\end{array}$ & - & $\begin{array}{l}-.093 \\
(.029)\end{array}$ & -- & 11.12 & 8.29 & .506 & .914 \\
\hline
\end{tabular}

SOURCE: SEe pp. 75-81

"Standard errors shown in parentheses below coefficients. CPI represents the consumer price index (1957-59 = 100.0); I capita dollar volume of consumer installment credit; PYTX, the percentage of personal income taxed; MILPOP, total military population on active duty as a percentage of total U.S. population; DEPMON, the ratio of total deposits (adjusted) in commercial banks to the total money supply (broadly defined to include time deposits at commercial, mutual savings, and postal savings banks in addition to currency and commercial bank demand deposits); BKSUS, a 5-year moving average of the number of commercial bank suspensions. The dollar value of the average denomination of U.S. currency is used as the dependent variable. 
rates (on Moody's AAA corporate securities) and the dollar volume of consumer installment credit (normalized- for changes in population). The introduction of these variables boosts the coefficient of determination substantially. However, given the possibly strong influence of "crisis" factors on the distribution of denominations (particularly during World War II), 22 there is reason to believe that additional variables should be included in regression estimates. Several other variables (which presumably reflect these influences) are introduced in the remaining equations. Although the results differ somewhat among these equations, each suggests that crisis factors were a major source of change in the distribution of denominations between 1923 and 1965. A "best fit" equation is selected from the eight equations. The estimates provided by this equation are used as a norm against which the observed behavior of the average denomination is compared.

\section{(2) The Simple Quantity Theory}

The results of a test for the operation of a simple quantitytheory type mechanism are depicted in line 1 of Table 6 . This test hypothesizes a direct proportional relationship between the level of prices and the average denomination. The results support the case for some sort of quantity theory type mechanism: the coefficient for prices is significantly positive and the coefficient of determination is quite high (.611). However, since the coefficient of determination is still substantially less than unity, a proportional relationship between

${ }^{22}$ See pp. 56-63 of the present study. 
prices and the average denomination can be questioned. ${ }^{23}$ The case against the simple quantity theory as applied to denominational demands is further strengthened when other measures of price behavior are substituted for the consumer price index. 24

\section{(3) Interest Rates and Installment Credit}

The empirical findings therefore suggest that the distribution of denominations depends upon some combination of factors, including prices. Equation (2) (Iine 2 of Table 6) introduces interest rates on high-grade corporate securities. This boosts the coefficient of determination to .817. The standard error of estimate is $\$ .693$ (or only 8.4 percent of the average denomination). The interest rate coefficient is shown to be highly significant and has the expected (negative) sign. This lends empirical support to the hypothesis that a rise in yields on financial assets (i.e., on substitutes for currency in the storing of wealth) tends to significantly reduce the average denomination of currency held. Equation (3) (Iine 3 of Table 6) introduces the per capita dollar volume of consumer installment credit. Together the three variables are shown to explain 84.2 percent of the variation in the average denomination over the sample period. The standard error of estimate is

23 The possibility of a proportional relationship between prices and the average denomination is discussed in Cagan, op. cit., p. I4. It is Cagan's contention that "a rise in prices tends to raise the average denomination of the currency proportionately. Inflation increases the average dollar amount of transactions, and so the average payment uses larger bills than before."

${ }^{24}$ The test for the operation of a quantity theory type mechanism was also performed using Friedman's series on "permanent prices" (an exponentialily weighted average of past and present prices). Although a significant positive relationship between permanent prices and the average denomination was discovered, the coefficient of determination was still far less than unity $(.643)$. 
only 7.8 percent of the average denomination. The coefficient for the credit variable is significantly negative, suggesting that the growth in installment credit over the period 1923-65 tended to significantly reduce the average denomination of currency in circulation.

A difficulty is that the variables included in equations (1)-(3) fail to take explicit account of "crisis" factors. Equations (4)-(8) attempt to correct for possible biases in the other equations by introducing separate "crisis" variables. As noted earlier, this may be done through the use of zero-one (or "dummy") variables, although this approach may introduce additional biases due to incorrect identification of crisis periods. For this reason the equations employ certain quantitative magnitudes which might reflect the existence of crises.

(4) Crisis Variables

Equation (4) (Iine 4 of Table 6) introduces the percentage of personal income taxed. This raises the coefficient of determination to .893. The standard error of estimate is only 6.4 percent of the average denomination. All coefficients are statistically significant and their signs are in the expected directions.

The positive coefficient of the tax variable might be interpreted in several ways. First, it lends empirical support to the hypothesis that a rise in the ratio of personal tax collections to total personal income tends to encourage tax evasion through the use of currency. In a . broader context, however, the tax variable may also serve as a reasonably good proxy for the existence of wartime uncertainties. World War II brought sudden, sharp increases in the percentage of personal income 
taxed (to a maximum of 11.8 percent in 1945), after two decades of relatively low and stable tax rates. In this context, the tax evasion over the sample period might be regarded as a war-related phenomenon. Equations (5) through (8) employ other variables relating to economic crises in an attempt to improve upon the "goodness of fit" of equation (4).25 In equation (5) a measure of relative military population is substituted for the tax variable. This variable is significantly positive. However, the equation represents a somewhat poorer "fit" than equation (4), since the coefficient of determination (.859) is lower and the standard error (.608) higher.

Equations (6) and (7) introduce the deposit-money ratio ${ }^{26}$ and a five-year moving average of commercial bank suspensions, respectively. The deposit-money ratio is statistically significant and the sign of its coefficient is negative. The bank suspension variable is statistically insignificant, although the sign of its coefficient is as expected (positive).27 Equations (6) and (7) represent poorer fits than equation (4), however, since they involve somewhat lower $\mathrm{R}^{2}$ 's and higher standard errors.

25 The "best fit" equation is the one with the highest coefficient of determination and lowest standard error.

${ }^{2} 26$ In designating the deposit-money ratio as a "crisis" variable we do not mean to imply that movements in the ratio are relevant only during crisis periods. The important point is that it (like the tax and other "crisis" variables) seems to be a particularly sensitive indicator of crisis pressures on the distribution of denominations.

27 It will be recalled that this variable represents a five-year moving average of bank suspensions. In an earlier test we experimented with other definitions of this variable (i.e., the absolute level of suspensions, and various other moving averages). The coefficient for this variable was insignificantly positive in each case. 
Equation (8) introduces the two "crisis" variables shown to be statistically significant in earlier findings (the percentage of personal income taxed and the deposit-money ratio). This results in a somewhat better fit than equation (4), since the coefficient of determination is slightly higher (.914), and the standard error slightly lower (.506). All five variables in equation (8) are statistically significant with the expected signs. This equation suggests that the average denomination of currency is directly related to the level of prices and percentage of personal income taxed, and inversely related to the volume of consumer credit, interest rates, and the deposit-money ratio. In the following section the estimates provided by this "best fit" equation are examined in light of observed changes in certain explanatory variables.

It should be noted that all eight equations (including the "best fit" estimator) may contain biases due to multicollinearity and/or serial correlation. Table 7 presents a matrix of simple correlation coefficients between each pair of the seven variables used in annual estimating equations. The only equations containing variables which are not highly interrelated are equations (1) and (2). In all other equations the simple correlation coefficients between independent variables are rather high. Equation ( 8 ) does have a decided advantage over the "unbiased" estimators (equations [1] and [2]) in that it contains several additional significant variables that conform with theoretical expectations.

The von Neumann and Durbin-Watson tests of serial correlation were applied to each of the eight equations. Positive serial correlation was 
TABLE 7

MATRIX OF SIMPLE CORRELATION COEFFICIENTS

BETWEEN SE'VEN EXXIAANATORY VARIABLES

(Annual. Data, 1923-65)

\begin{tabular}{|c|c|c|c|c|c|c|c|}
\hline & $\mathrm{CPI}$ & $I_{\text {aaa }}$ & PYTX & CRDPOP & MILPOP & BKSUS & DEPMON \\
\hline CPI & -- & -.002 & .878 & .913 & .123 & -.635 & .388 \\
\hline$I_{\text {gaa }}$ & -.002 & -- & -.343 & .130 & -.469 & .439 & .311 \\
\hline PYTX & .878 & -.343 & - & .742 & .502 & -.715 & .140 \\
\hline CRDPOP & .913 & .130 & .742 & - & .005 & -.489 & .292 \\
\hline MILPOP & $\cdot .123$ & -.469 & .502 & .005 & -- & -.407 & -.099 \\
\hline BKSUS & -.635 & .439 & -.715 & -.489 & -.407 & -- & -.455 \\
\hline DEPMON & .388 & .311 & .140 & .292 & -.099 & -.455 & -- \\
\hline
\end{tabular}

SOURCE: See pp. $75-8 i$ 
TABLE B

DEMAND ESTIMATES FOR DENOMINATIONS USING FIRST DIFFERENCE DATA,

1923-65*

(Annual Values Expressed us First Differences)

\begin{tabular}{|c|c|c|c|c|c|c|c|c|c|c|c|}
\hline . & $\mathrm{CPJ}$ & $I_{\text {aas }}$ & CRDPOP & PYTX & MILP()P & DEPMON & BKSUS & 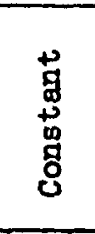 & 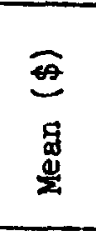 & 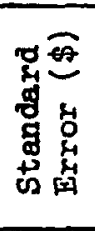 & 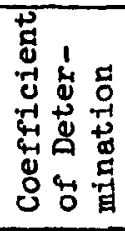 \\
\hline Equation 1 & $\begin{array}{r}-.012 \\
(.019)\end{array}$ & - & - & -- & -- & - & - & .060 & .045 & .368 & .033 \\
\hline Bquation 2 & $\begin{array}{l}-.015 \\
(.019)\end{array}$ & $\begin{array}{l}.259 \\
(.162)\end{array}$ & -- & -- & -- & - & -- & .067 & .045 & .361 & .070 \\
\hline Equation 3 & $\frac{-.011}{(.018)}$ & $\left(\begin{array}{l}.345 \\
(.161)\end{array}\right.$ & $\begin{array}{l}-.010 \\
(.005)\end{array}$ & -- & $-\infty$ & -- & - & .142 & .045 & .347 & .145 \\
\hline Equation 4 & $\begin{array}{l}-.020 \\
(.019)\end{array}$ & $(.327$ & $\begin{array}{l}-.008 \\
(.005)\end{array}$ & $\begin{array}{l}.058 \\
(.045)\end{array}$ & - & $-\infty$ & - & .123 & .045 & .344 & .221 \\
\hline Bquation 5 & $\begin{array}{l}-.012 \\
(.018)\end{array}$ & $\begin{array}{l}.335 \\
(.163)\end{array}$ & $\frac{-.009}{(.005)}$ & - & $\begin{array}{l}.028 \\
(.043)\end{array}$ & - & - & .136 & .045 & .349 & .110 \\
\hline Equation 6 & $(.027)$ & $(.035)$ & $=(.004)$ & -- & $-\infty$ & $\begin{array}{l}-. .139 \\
(.036)\end{array}$ & $-\infty$ & .041 & .045 & .296 & .378 \\
\hline Equation 7 & $\begin{array}{l}-.009 \\
(.019)\end{array}$ & $\left(\begin{array}{l}.356 \\
(.263)\end{array}\right.$ & $\begin{array}{l}-.010 \\
(.005)\end{array}$ & $-\infty$ & - & - & $(.0002)$ & .142 & .045 & .349 & .134 \\
\hline Dquation 8 & $(.018)$ & $\begin{array}{l}.018 \\
(.156)\end{array}$ & $\frac{-.002}{(.004)}$ & $\begin{array}{l}.057 \\
(.039)\end{array}$ & - & $\begin{array}{l}-. .138 \\
(.035)\end{array}$ & - & .022 & .045 & .291 & .399 \\
\hline
\end{tabular}

SOURCE: See pp. $75-81$

- Standard errors shown in parentheses below coefficients. CPI represents the consumer price index (1957-59 = 100.0);

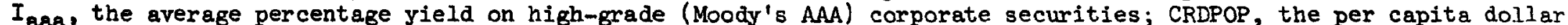
volume of consumer installment credit; PYTX, the percentage of personal income taxed; MILPOP, total military population on active duty as a percentage of total U.S. population; DEPMON, the ratic of total deposits (adjusted) in commercial banks to the total money supply (broadly derined to include time deposits at commercial, mutual savings, and postal savings banks in addition to currency and conmercjal bank demand deposits); BKSUS, a 5-year moving average of the number of commercial bank suspensions. The dollar value of the average denomination of

U.S. currency is used as the dependent variable. 
TABLE 9

DEMAND ESTIMATES FOR DENOMINATIONS USING BOTH FIRST DIFFERENCES

AND LEVELS OF THE DATA, 1923-65*

(Annual Values Expressing Dependent Variable as a First Difference and Independent Variables as Levels)

\begin{tabular}{|c|c|c|c|c|c|c|c|c|c|c|c|}
\hline & $\mathrm{CPI}$ & $I_{\text {aas }}$ & CRDPOP & PYTX & MILPOP & DEPMON & BKSUS & $\begin{array}{l}+ \\
\text { a } \\
0 \\
\text { g } \\
8 \\
0\end{array}$ & 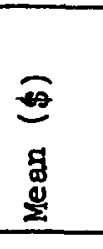 & 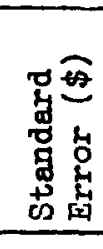 & 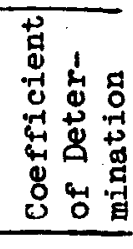 \\
\hline Equation 1 & $\begin{array}{l}-.003 \\
(.003)\end{array}$ & -- & - & -- & -- & - & -- & .279 & .045 & .363 & .060 \\
\hline Equation 2 & $\begin{array}{l}. .003 \\
(.003)\end{array}$ & $\begin{array}{l}-.096 \\
(.066)\end{array}$ & - & -- & $\cdots$ & - & -- & .625 & .045 & .358 & .087 \\
\hline Equation 3 & $\begin{array}{l}-.008 \\
(.007)\end{array}$ & $\begin{array}{l}.120 \\
(.071)\end{array}$ & $(.001)$ & -- & $-\infty$ & - & - & .978 & .045 & .359 & .082 \\
\hline Equation 4 & $\begin{array}{l}-.035 \\
(.008)\end{array}$ & $\begin{array}{l}.109 \\
(.078)\end{array}$ & $\begin{array}{l}.002 \\
(.001)\end{array}$ & $\begin{array}{l}.118 \\
(.027)\end{array}$ & -- & - & $-m$ & 1.22 & .045 & .295 & .382 \\
\hline Equation 5 & $\begin{array}{l}-.012 \\
(.006)\end{array}$ & $\begin{array}{l}-.014 \\
(.067)\end{array}$ & $\begin{array}{l}.002 \\
(.001)\end{array}$ & - & $\begin{array}{l}.105 \\
(.027)\end{array}$ & - & -- & .649 & .045 & .308 & .308 \\
\hline Equation 6 & $\begin{array}{l}-.004 \\
(.007)\end{array}$ & $\begin{array}{l}-.074 \\
(.076)\end{array}$ & $(.001)$ & - & - & $\begin{array}{l}-.031 \\
(.020)\end{array}$ & -- & 2.78 & .045 & .352 & .216 \\
\hline Equation 7 & $\begin{array}{l}-.014 \\
(.007)\end{array}$ & $\begin{array}{c}-.035 \\
(.084)\end{array}$ & $\begin{array}{l}.002 \\
(.002)\end{array}$ & -- & - & - & $\begin{array}{c}-.0003 \\
(.0002)\end{array}$ & 1.15 & .045 & .349 & .131 \\
\hline Equation 8 & $\begin{array}{l}-.034 \\
(.010)\end{array}$ & $\begin{array}{l}.110 \\
(.079)\end{array}$ & $\begin{array}{l}.002 \\
(.001)\end{array}$ & $\begin{array}{l}.116 \\
(.029)\end{array}$ & $\cdots$ & $\begin{array}{l}-.004 \\
(.018)\end{array}$ & -- & 1.43. & .045 & .299 & .366 \\
\hline
\end{tabular}

SOURCE: See pp. $75-81$

"Standard errors shown in parentheses below coefficients. CPI represents the consumer price index (1957-59 = 100.0); $I_{\text {aas, }}$ the average percentage yield on high-grade (Moody's AAA) corporate securities; CRDPOP, the per capita dollar volume of consumer installment credit; PYTX, the percentage of personal income taxed; MILPOP, total military population on active duty as a percentage of total U.S. population; DEPMON, the ratio of total deposits (adjusted) in commercial banks to the total money supply (broady derined to include time deposits at commercial, muturl savings, and postal savings banks in addition to currency and commercial bank demand deposits); BKSUS, a $5-y(u)$ moving average of the number of commercial bank suspensions. The doliar value of the average denomination of U.S. currency is used as the dependent variable. 
present at both the .01 and .05 levels of significance. The equations were re-run using first differences of certain variables. The results (depicted in Tables 8 and 9) were somewhat disappointing. Serial correlation was still significant at the .05 level. In addition, these equations show a large number of statistically insignificant coefficients and unexpected signs. Table 8, for example, depicts results using first differences of all variables (including the dependent variable). The only variable in these equations which is consistently significant in the expected direction is the deposit-money ratio. The equations shown in Table 9 employ the levels of all variables except for the dependent variable (which is expressed as a first difference). In these equations the only variables which are consistently significant with the expected signs are the ones measuring the percentage of personal income taxed and the relative military population. In view of these unsatisfactory results, we chose to designate equation (8) in its original form (as shown in Table 6) as the "best fit" equation, in spite of the statistical biases which it may contain.

\section{(5) Examination of "Best Fit" Estimates}

The "best fit" estimates provided by equation (8) represent a norm against which the observed behavior of the average denomination may be compared. These estimates are shown in Table 10 and Figure 1.

The time path traced out by estimates computed from equation (8) does not appear unreasonable. While not in complete agreement with observed changes in the average denomination, these estimates suggest that the "best fit" equation incorporates some of the more important mechanisms which influence the distribution of denominations. This is 
particularly apparent during the period 1931-65. Both the observed and the estimated series rise during the Depression and fall off in the midThirties. During the Second World War both series show rapid gains, followed by generally moderate declines over the postwar period.

Equation (8) performs less well in reproducing movements in the average denomination during the Twenties: the estimated series is reasonably stable during the 1920's, while the observed series declines very rapidly. It may be instructive to examine the estimates in light of observed changes in certain variables which influence the distribution of denominations.

\section{(a) The Twenties}

In Chapter II the rapid decline in the average denomination between 1923 and 1930 was interpreted as an indication of rising relative transactions demands for currency. Over this period most of the explanatory variables behaved in a way which would suggest a decline in the average denomination. Prices were fairly stable following severe inflationary pressures during World War I. Interest rates were quite high. The depositmoney ratio was high and rising throughout most of the decade. The estimates computed from equation (8) do not appear to mirror these influences. One reason for this may be that these tendencies are obscured by overall trends in the variables between 1923 and 1965. (Only seven of the forty-three observations included in the "best fit" equation are drawn from the 1920's).

(b) The Thirties

The estimates are somewhat more satisfactory during the 1930's. It will be recalled that the observed series grew rapidly between 
TABLE 10

FACTORS AFFECTING THE AVERAGE DENOMINATION OF CURRENCY, 1923-65

(In Dollars)

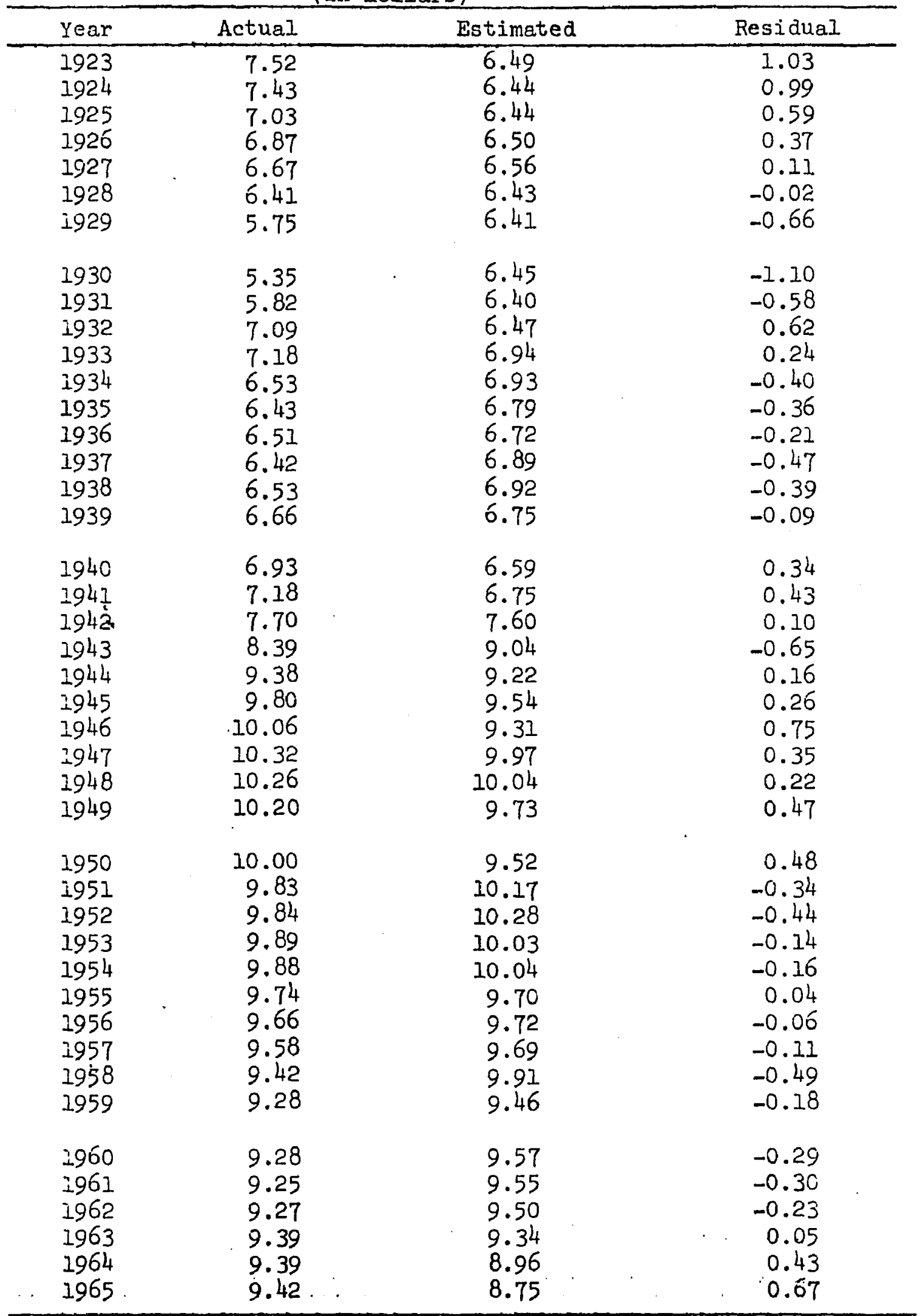

SOURCE; See pp. 7.5-8i. 
mid-1930 and mid-1933, a movement which was traced to falling interest rates, declining public confidence in the ability of banks to make payments, etc. The estimated series shows a similar tendency (although the rise does not begin until mid-1931). Both series reach a peak in mid1933. The estimated series levels off over the following year (as the observed series declines rapidly), but then falls off through mid-1936.

Discrepancies between the two series can be detected over the remainder of the decade. While the observed series rises rapidly between mid-1937 and mid-1940, the estimated series shows a brief increase through mid-1938 and then declines quite sharply through mid-1940. Part of the decline in the estimated series may be due to the price deflation between 1937 and 1938.

\section{(c) The Second World War}

An important characteristic of the estimates is that they trace out a time path which is in extremely close agreement with the observed time path during the Second World War. Movements in the two series are almost identical between 1940 and 1945. This is as expected, in light of the rising prices, relatively low interest rates, increased taxation of personal income and fairly low ratio of deposits to total money which we associate with this period.

\section{(d) The Postwar Period-}

Over the postwar period the general tendency is for a decline in both the estimated and observed series, although the downward trend in the latter is somewhat more regular than that in the former. The correspondence between the two series is not surprising in view of the easing of upward pressures on prices and generally high yields on financial 
assets over this period. In addition, the decline in the observed series also may have resulted from an easing of pressures on the distribution of denominations originally triggered by the war. However, the tax variable may be a poor proxy for these pressures during the postwar period. The percentage of personal income rises in the early 1950's and tends to remain at these higher levels through 1965. This may help to explain why the estimates tend to overstate the value of the average denomination during the Fifties and early Sixties.

Other discrepancies can also be detected. The observed series continues its wartime rise through mid-1947. The estimated series falls off slightly between mid-1945 and mid-1946 (possibly due to a decline in tax rates), but rises rapidly through mid-1948. Over the rest of the decade both series decline.

The estimated series increases quite rapidly again between mid1950 and mid-1.952 (possibly as a result of sharp gains in prices and tax rates during the Korean War). For the remainder of the decade the trend in this series is generally downward (except for a brief rise between mid-1957 and mid-1958).

The 1960-65 results are reasonably good. From mid-1960 to mid1962 both series are stable-to-moderately declining. Thereafter large discrepancies between the series develop: the observed series increases slightly, while the estimated series shows quite rapid declines. The behavior of the estimates may be due in part to large gains in consumer credit and the high levels of interest rates which characterize the 1962-65 period. 
(C) Denominational Demands and Lagged Responses

A possible source of bias in the regression estimates may be their failure to account for the time shape of demand reactions. From what can be inferred about the transactions costs of adjusting denominational holdings, one might reasonably assume that the lag in the adjustment of actual to desired holdings is extremely short. However, a significant lag may exist between desired holdings and certain explanatory variables, to the extent that individuals react to past values of these variables. If this is so, it may be possible to improve regression estimates through introducing lagged values of certain variables. ${ }^{28}$

The tests for lagged reactions in the distribution of denominations were made first using annual values of certain explanatory variables discussed in section (B). An additional variable, the average denomination lagged one year, was introduced into each equation. The results appear in Table 11. Column 7 of this table deplcts estimates of the length of the lag. 29

There is reason to believe that the lag structure is not properly specified in any of the equations involving annual values. In equations (1) and (3) the lag hypothesis yields an inconsistent estimate of the lag itself, since the coefficient for the lagged average denomination

${ }^{28}$ In the following we make the simplifying assumption that the average denomination reacts with a lag of the same length upon all the explanatory variables of the estimator equation. For a discussion of this and other assumptions relating to the use of lagged variables see Robert Ferber and P. J. Verdoorn, Research Methods in Economics and Business (New York: The Macmillan Company, 1962), pp. 372-80.

29 The estimated length of the lag is equal to $\beta /(1-\beta)$, where $\beta$ is the coefficient for the lagged variable. 
TABLE Il

ESTIMATES OF LAGGED RESPONSES IN THE DEMAND FOR DENOMINATIONS OF CURRENCY, 1923-65a

(Annual Values)

\begin{tabular}{|c|c|c|c|c|c|c|c|c|c|c|c|}
\hline & $\begin{array}{l}\text { AVE } \\
\text { LAG }\end{array}$ & CPI & $I_{\text {aad }}$ & CRIJPOP & PYTX & DEPMON & $\begin{array}{l}\text { Est. } \\
\text { length } \\
\text { of LAG } \\
\text { (yrs.) }\end{array}$ & 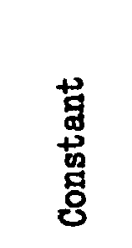 & 冤兽 & 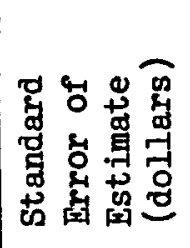 & 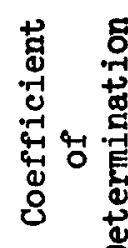 \\
\hline Bquation 1 & $\begin{array}{l}1.04 \\
(.063)\end{array}$ & $\begin{array}{l}-.006 \\
(.004)\end{array}$ & -- & - & - & -- & $\mathbf{b}$ & .113 & 8.26 & .361 & .950 \\
\hline Equation 2 & $\begin{array}{l}.963 \\
(.088)\end{array}$ & $(.001)$ & $\begin{array}{l}-.115 \\
(.090)\end{array}$ & - & -- & -- & 26.0 & .851 & 8.26 & .358 & .951 \\
\hline Equation 3 & $\begin{array}{l}1.00 \\
(.106)\end{array}$ & $\begin{array}{l}-.008 \\
(.012)\end{array}$ & $\begin{array}{c}-.104 \\
(.092)\end{array}$ & $(.001)$ & - & -- & b & .898 & 8.26 & .360 & .949 \\
\hline Equation 4 & $\begin{array}{l}.879 \\
(.090)\end{array}$ & $\begin{array}{l}-.025 \\
(.010)\end{array}$ & $\begin{array}{l}.075 \\
(.083)\end{array}$ & $\left(\begin{array}{l}.001 \\
(.003)\end{array}\right.$ & $\begin{array}{l}.129 \\
(.028)\end{array}$ & -- & 7.3 & 1.68 & 8.26 & .290 & .967 \\
\hline Equation 5 & $\begin{array}{l}.844 \\
(.100)\end{array}$ & $\begin{array}{l}.018 \\
(.014)\end{array}$ & $\begin{array}{l}.066 \\
(.084)\end{array}$ & $(.000)$ & $(.122)$ & $\begin{array}{c}-.016 \\
(.020)\end{array}$ & 5.4 & 2.71 & 8.26 & .291 & .966 \\
\hline
\end{tabular}

SOURCE: SEe Pp. 75-81

a) Standard errors shown below coefficients in parentheses. AVE LAG represents the coefficient. for the average denomination lagged one year; CPI, the consumer price index; $I_{\text {aaa }}$, the average yield on high-grade (Moody's AAA) corporate securities; CRDPOP, the per capita dollar volume of consumer installment credit; PYTX, the percentage of personal income taxed; DEPMON, the ratio of total deposits (adjusted) in commercial banks to the total money supply (broadly defined to include time deposits at commercial, mutual savings and postal savings banks in addition to currency and commercial bank demand deposits).

b) The equation provides an inconsistent estimate of the lag. 
is not less than unity. 30 The remaining equations meet this requirement but contrast sharply with those presented in Table 6 . Each of the three equations suggests that the lag in the adjustment of denominations is fairly long. Equation (5), for example (which comes closest to approximating the form of the "best fit" equation discussed in the last section), implies a lag of 5.4 years. This result should not be taken too seriously, however, since the equation contains a number of statistically insignificant coefficients and unexpected signs. Similar ambiguities are found in equations (2) and (5). The only coefficients shown to be consistently significant in each of these equations are the ones for the lagged average denomination and the tax variable.

Several tests for lagged responses were made using monthly values for consumer prices and interest rates on high-grade corporate (Moody's AAA) securities. 31 In adition, each of the equations used in these tests introduced dummy variables for eleven months (January through November); ${ }^{32}$ this was done to account for the expected strong influence of seasonal factors on denominational holdings. The equations cover the period May, 1933,33 to December, 1965. The regression results are depicted in Table 12.

${ }^{30}$ See Ferber and Verdoorn, op. cit., p. 340.

${ }^{31}$ The use of monthly (as against annual) data in regression estimates has two advantages: (I) it allows for greater precision in the estimation of lags; and (2) it permits us to test for the operation of seasonal forces. The second point is examined in detail in Chapter IV.

${ }^{32}$ See Chapter IV for a discussion of the meaning of these variables. ${ }^{3} 3_{\mathrm{May}}, 1933$ was chosen as the first observation since this is the date on which complete monthly statistics on U.S. currency denominations became available. It was not possible to replicate any of the other equations from the previous section since statistics on other explanatory variables are not available on a monthly basis as early as this date. 
TABIE 12

ESTIMATES OF THE DEMAND FOR DENOMINATIONS OF CURRENCY,

MAY, 1933--DECEMBER, 1965*

(Monthly Velues)

\begin{tabular}{|c|c|c|c|c|c|c|c|c|c|c|c|c|c|c|c|}
\hline quation 1 & $\begin{array}{l}-.005 \\
(.003)\end{array}$ & $\begin{array}{l}.0002 \\
(.0002)\end{array}$ & $\begin{array}{l}-.020 \\
(.005)\end{array}$ & $\begin{array}{l}.204 \\
(.009)\end{array}$ & $\begin{array}{l}.057 \\
(.009)\end{array}$ & $\begin{array}{l}.039 \\
(.009)\end{array}$ & $\begin{array}{l}.039 \\
(.009)\end{array}$ & $\begin{array}{l}.006 \\
(.009)\end{array}$ & $(.063)$ & $\begin{array}{l}.060 \\
(.009)\end{array}$ & & & & $(.031)$ & $(.051)$ \\
\hline Equation 3 & - & $(.004)$ & $\begin{array}{l}-.039 \\
(.027)\end{array}$ & $\begin{array}{l}.208 \\
(.009)\end{array}$ & $\begin{array}{l}.058 \\
(.009)\end{array}$ & $\begin{array}{l}.039 \\
(.009)\end{array}$ & $\begin{array}{l}.038 \\
(.009)\end{array}$ & $\begin{array}{l}.006 \\
(.009)\end{array}$ & $(.064)$ & $\begin{array}{l}.063 \\
(.009)\end{array}$ & $\begin{array}{l}.039 \\
(.008)\end{array}$ & $\left(\begin{array}{l}.014 \\
(.008)\end{array}\right.$ & $\left(\begin{array}{l}.043 \\
(.008)\end{array}\right.$ & $\begin{array}{l}.029 \\
(.008)\end{array}$ & \\
\hline Equation 5 & -- & $\begin{array}{l}.212 \\
(.132)\end{array}$ & $\begin{array}{c}-.011 \\
(.003)\end{array}$ & $\begin{array}{l}.209 \\
(.008)\end{array}$ & $\begin{array}{l}.058 \\
(.008)\end{array}$ & $\begin{array}{l}.039 \\
(.008)\end{array}$ & $\begin{array}{l}.037 \\
(.008)\end{array}$ & $\begin{array}{l}.005 \\
(.008)\end{array}$ & $\begin{array}{l}.063 \\
(.008)\end{array}$ & $\begin{array}{l}.063 \\
(.008)\end{array}$ & $\begin{array}{l}.037 \\
(.008)\end{array}$ & $\begin{array}{l}.012 \\
(.008)\end{array}$ & $\begin{array}{l}.043 \\
(.008)\end{array}$ & $\begin{array}{l}.028 \\
(.008)\end{array}$ & $\frac{-.008}{(.011)}$ \\
\hline Equation 6 & - & $\begin{array}{l}.095 \\
(.044)\end{array}$ & $\begin{array}{l}-.010 \\
(.003)\end{array}$ & $\begin{array}{l}.209 \\
(.008)\end{array}$ & $\begin{array}{l}.058 \\
(.008)\end{array}$ & $\begin{array}{l}.038 \\
(.008)\end{array}$ & $\begin{array}{l}.038 \\
(.008)\end{array}$ & $\begin{array}{l}.005 \\
(.008)\end{array}$ & $\begin{array}{l}.064 \\
(.008)\end{array}$ & $\begin{array}{l}.064 \\
(.008)\end{array}$ & $\begin{array}{l}.039 \\
(.008)\end{array}$ & $\begin{array}{l}.013 \\
(.008)\end{array}$ & $(.044)$ & $\begin{array}{l}.029 \\
(.008)\end{array}$ & $\begin{array}{l}-.012 \\
(.012)\end{array}$ \\
\hline
\end{tabular}

SOURCE: See pp. $75-81$.

"Standard errors shown in parentheses below coefficients, The dollar value of the ayerage denomination of U.S. currency (expressed as a first difference) is used as the dependent variable in all equations. AVELAG is the average denomination lagged one month. CPI is the consumer price index $(1957-59=100.0)$. Iaaa is the average percentage yield on high-grade (Moody's AAA) corporate securities. JAN, FEB, MAR...NOV are the dummy variables for eleven months, January through November. In equation 1 CPI and $I_{\text {aas }}$ are expressed as levels. In equations 2 and 3 changes in these variables are lagged 3 months and 12 months, respectively. In equations 4-6 the current levels of $I_{\text {aag }}$ are used. The same equations employ lagged percentage changes in CPI (over 1 month in equation 4,3 months in equation 5 ond 12 months in equation 6 ). 
The results of the first test for a lagged adjustment are shown in Iine 1 of Table 12. The average denomination of U.S. currency (expressed as a first difference to reduce serial correlation biases) was used as the dependent variable. The independent variables included (I) the levels of consumer prices, interest rates and the average denomination (lagged one month), and (2) the eleven monthly dummies. The results were somewhat disappointing. While the signs of the coefficients for the variables were in the expected directions and the coefficient of determination was reasonably high (.687), several economic variables (consumer prices and the lagged average denomination) and dummy variables (for May and September) were statistically insignificant. Serial correlation was present at the. .05 level. The estimate of the lag was somewhat ambiguous: the coefficient for the average denomination (lagged one month) was -.005, which would suggest a lag in excess of ninety-nine months. This result should not be taken seriously.

An alternative approach to the matter of lagged responses involves introducing lagged values of prices and interest rates into the regressions. The results appear in equations (2)-(6) of Table 12. The fundamental assumption of equations (2) and (3) is that the average denomination reacts with a lag of the same length upon both prices and interest rates. In each equation the average denomination (expressed as a first difference) is used as the dependent variable. Equation (2) tests for the presence of a quarterly lag through introaucing three period differences of prices and interest rates (both lagged one quarter) as independent variables. Equation (3) tests for a somewhat longer lag and employs twelve period differences of prices and 
interest rates (both lagged one year) as independent variables. Monthly dummy variables are also used in these equations.

The results of these regressions are quite good in terms of the signs of the individual coefficients and the statistical significance of seasonal patterns, but poor in terms of the hypothesized lag. The sign of the price coefficient is positive, while the one for interest rates is negative. Each of the dummy coefficients (except for May and September) is statistically significant and the coefficients of determination are quite high (.710 in both equations). However, neither of the lagged economic variables are statistically significant and serial correlation is present at the .05 level.

The results change substantially when the assumption that the average denomination reacts with a lag to both prices and interest rates is dropped. This is done in equations $(4)-(6)$. The form of the dependent variable and monthly dummy variables is unchanged from equations (1)-(3). The interest rate and consumer price variables are redefined. These equations hypothesize that the monthly change in denominational holdings reflects an adjustment to current levels of interest rates and percentage changes in consumer prices over some given period. To put it differently, the prices of currency substitutes which prevailed in some earlier period are assumed to have no effect upon the adjustment of denominations, although previous prices of consumer goods are assumed to influence these holdings. One interpretation of this last point is that individuals and businesses will carry higher denominations for use in current transactions because they have observed $a$ rise in prices over some given time period. The problem thus becomes one of determining the length of the . 
interval over which price changes will significantly affect the distribution of denominations. Equations (4)-(6) hypothesize intervals of one month, one quarter, and one year, respectively.

As shown in Table 12, the regression results are quite good not only in terms of the number (and signs) of statistically significant coefficients, but also in terms of one of the lag hypotheses. The coefficients of determination fall within the range .725 to .727 . Serial correlation is present at the .05 level in all three equations. The interest rate coefficient is significantly negative in each. The price coefficient is significantly positive when a twelve-month lag is employed, but insignificantly positive when lags of a shorter duration are used. The former result appears in equation (6). This equation suggests that the denominational holdings of individuals and businesses reflect (I) a significant lagged response (of at least one year) to changes in the prices of consumer goods in addition to (2) a significant (non-lagged) response to levels of interest rates and seasonal factors. 


\section{CHAPTER IV}

Seasonal Variation in the Distribution of

Currency Denominations, 1948-65

Estimates of seasonal patterns in the demand for denominations of U.S. currency are shown for the period January, $1948^{1}$ to December, 1965 in Table 13 and Figures 4-6. These findings show the influence of seasonal factors on selected denominations (and groupings of denominations $)^{2}$ as of the end of each of twelve months. ${ }^{3}$ The technique employed to isolate these influences involves the use of dummy variables

If observations from years prior to 1948 are included, the risks of bias due to special wartime factors are increased. Also, there is the possibility that seasonal patterns in the postwar years may differ from those of earlier years, due to important differences in the manner in which payments were made and wealth was stored between the two periods.

${ }^{2}$ The denominations selected for tests of seasonal influences include coin, $\$ 1, \$ 5, \$ 10, \$ 20, \$ 50, \$ 100, \$ 500$ and $\$ 1,000$ bills.

${ }^{3}$ Since the coefficients represent end-of-month values, certain important details might be obscured. December coefficients, for example, might not truly represent the effect which Christmas buying has upon the distribution of denominations, since the coefficient is given as of one week after Christmas. Since denominational data is compiled as of the end of the month, it is not possible to estimate seasonal coefficients for any other part of the month. 
TABLE 13

Estimates of Seasonal Coefficients for Selected Currency Denominations, 1948-65* (Monthly Values)

\begin{tabular}{|c|c|c|c|c|c|c|c|c|c|c|c|c|c|c|}
\hline $\begin{array}{l}\text { Denomination } \\
\text { of Currency }\end{array}$ & JAN & FEB & MARCH & APRIL & MAY & JUNE & JULY & AUG & SEPT & OCT & NOV & DEC & MEAN & $\mathrm{R}^{2}$ \\
\hline Average & $\begin{array}{l}16.67 \\
(.464)\end{array}$ & $\begin{array}{l}.900 \\
(.464)\end{array}$ & -1.62 & $\begin{array}{l}-1.99 \\
(.464)\end{array}$ & $\begin{array}{l}-4.89 \\
(.464)\end{array}$ & $\begin{array}{l}1.15 \\
(.464)\end{array}$ & $\begin{array}{c}2.74 \\
(.464)\end{array}$ & $\begin{array}{l}-.444 \\
(.464)\end{array}$ & $\frac{-5.11}{(.464)}$ & $\frac{-2.64}{(.464)}$ & $\begin{array}{l}-2.91 \\
(.464)\end{array}$ & $\begin{array}{l}-7.01 \\
(.464)\end{array}$ & -.43 & .903 \\
\hline $\begin{array}{l}\text { Small Bills } \\
\text { Ratio }\end{array}$ & $\begin{array}{l}-.493 \\
(.018)\end{array}$ & $\begin{array}{c}.138 \\
(.018)\end{array}$ & $\begin{array}{l}.087 \\
(.018)\end{array}$ & $\begin{array}{l}.029 \\
(.018)\end{array}$ & $\begin{array}{l}.206 \\
(.018)\end{array}$ & $(.117$ & $\frac{-.013}{(.018)}$ & $(.026)$ & $\begin{array}{l}-.040 \\
(.018)\end{array}$ & $\begin{array}{l}.000 \\
(.018)\end{array}$ & $\begin{array}{l}.253 \\
(.018)\end{array}$ & $\begin{array}{c}-.223 \\
(.018)\end{array}$ & +.01 & .865 \\
\hline Coin & $(.008)$ & $\begin{array}{l}.010 \\
(.008)\end{array}$ & $\begin{array}{l}.037 \\
(.008)\end{array}$ & $\begin{array}{l}.047 \\
(.008)\end{array}$ & $\frac{-.006}{(.008)}$ & $\frac{-.000}{(.008)}$ & $\begin{array}{l}.027 \\
(.008)\end{array}$ & $\begin{array}{l}.016 \\
(.008)\end{array}$ & $\begin{array}{l}.038 \\
(.008)\end{array}$ & $\begin{array}{l}.023 \\
(.008)\end{array}$ & $\begin{array}{l}-.046 \\
(.008)\end{array}$ & $\frac{-.000}{(.008)}$ & +.02 & .543 \\
\hline$\$ 1$ & $\begin{array}{l}-.130 \\
(.004)\end{array}$ & $\begin{array}{l}-.022 \\
(.004)\end{array}$ & $(.009)$ & $\begin{array}{l}.019 \\
(.004)\end{array}$ & $\begin{array}{l}.037 \\
(.004)\end{array}$ & $\begin{array}{l}-.015 \\
(.004)\end{array}$ & $\begin{array}{l}-.018 \\
(.004)\end{array}$ & $\begin{array}{l}.002 \\
(.004)\end{array}$ & $\begin{array}{l}.054 \\
(.004)\end{array}$ & $\begin{array}{l}.028 \\
(.004)\end{array}$ & $\begin{array}{l}.007 \\
(.004)\end{array}$ & $\begin{array}{l}.085 \\
(.004)\end{array}$ & .00 & .882 \\
\hline$\$ 5$ & $\begin{array}{l}-.158 \\
(.006)\end{array}$ & $\begin{array}{l}.007 \\
(.006)\end{array}$ & $(.006)$ & $\frac{-.006}{(.006)}$ & $\begin{array}{l}.042 \\
(.006)\end{array}$ & $\begin{array}{l}-.028 \\
(.006)\end{array}$ & $\begin{array}{l}-.047 \\
(.006)\end{array}$ & $(.006)$ & $\begin{array}{l}.016 \\
(.006)\end{array}$ & $\begin{array}{l}.008 \\
(.006)\end{array}$ & $(.050)$ & $(.066)$ & .00 & .846 \\
\hline$\$ 10$ & $(. .295)$ & $\begin{array}{l}.132 \\
(.014)\end{array}$ & $\begin{array}{l}.037 \\
(.014)\end{array}$ & $\begin{array}{l}-.032 \\
(.014)\end{array}$ & $\begin{array}{l}.094 \\
(.014)\end{array}$ & $(.023)$ & $\begin{array}{l}-.092 \\
(.014)\end{array}$ & $=(.002)$ & $\begin{array}{l}-.049 \\
(.014)\end{array}$ & $\begin{array}{l}-.039 \\
(.014)\end{array}$ & $\begin{array}{l}.165 \\
(.014)\end{array}$ & $(. .222)$ & -.01 & .796 \\
\hline$\$ 20$ & 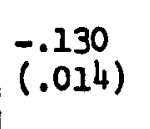 & $(.025)$ & $=(.000)$ & $\frac{-.001}{(.014)}$ & $\begin{array}{l}.042 \\
(.014)\end{array}$ & $\begin{array}{l}.139 \\
(.014)\end{array}$ & $\begin{array}{l}.116 \\
(.014)\end{array}$ & $\begin{array}{l}.014 \\
(.014)\end{array}$ & $\begin{array}{l}-.100 \\
(.014)\end{array}$ & $\begin{array}{l}-.019 \\
(.014)\end{array}$ & $\begin{array}{l}.077 \\
(.014)\end{array}$ & $\begin{array}{l}-.154 \\
(.014)\end{array}$ & .00 & .688 \\
\hline$\$ 50$ & $\begin{array}{l}.106 \\
(.005)\end{array}$ & $\begin{array}{l}-.052 \\
(.005)\end{array}$ & $\begin{array}{c}-.034 \\
(.005)\end{array}$ & $(.002)$ & $\begin{array}{l}-.045 \\
(.005)\end{array}$ & -.007 & $\begin{array}{l}.005 \\
(.005)\end{array}$ & $\begin{array}{l}-.018 \\
(.005)\end{array}$ & $\begin{array}{l}-.016 \\
(.005)\end{array}$ & -.016 & $\begin{array}{l}-.049 \\
(.005)\end{array}$ & $\begin{array}{l}.105 \\
(.005)\end{array}$ & .00 & .872 \\
\hline$\$ 100$ & $\begin{array}{l}.357 \\
(.012)\end{array}$ & $(.071)$ & $\begin{array}{l}-.048 \\
(.012)\end{array}$ & $\begin{array}{l}-.013 \\
(.012)\end{array}$ & $\frac{-.132}{(.012)}$ & $\begin{array}{l}-.089 \\
(.012)\end{array}$ & $\begin{array}{l}.019 \\
(.012)\end{array}$ & $\begin{array}{l}.011 \\
(.012)\end{array}$ & $(.068)$ & $\begin{array}{l}.042 \\
(.012)\end{array}$ & $\begin{array}{l}-.158 \\
(.012)\end{array}$ & $\begin{array}{l}.116 \\
(.012),\end{array}$ & +.01 & .863 \\
\hline$\$ 500$ & $\begin{array}{l}.020 \\
(.001)\end{array}$ & $\begin{array}{l}-.004 \\
(.001)\end{array}$ & $(.003)$ & $\begin{array}{l}-.004 \\
(.001)\end{array}$ & $-(.011)$ & $\begin{array}{l}-.010 \\
(.001)\end{array}$ & $\begin{array}{l}-.004 \\
(.001)\end{array}$ & -.008 & -.003 & $\begin{array}{l}-.007 \\
(.001)\end{array}$ & $\begin{array}{l}-.015 \\
(.001)\end{array}$ & $\begin{array}{l}-.001 \\
(.001)\end{array}$ & .00 & .749 \\
\hline$\$ 1000$ & $(.021)$ & $\begin{array}{l}-.011 \\
(.003)\end{array}$ & $\begin{array}{l}-.004 \\
(.003)\end{array}$ & $\begin{array}{l}-.008 \\
(.003)\end{array}$ & $\begin{array}{l}-.016 \\
(.003)\end{array}$ & $\begin{array}{l}-.013 \\
(.003)\end{array}$ & $\begin{array}{l}-.006 \\
(.003)\end{array}$ & $\begin{array}{l}-.012 \\
(.003)\end{array}$ & $\begin{array}{l}-.010 \\
(.003)\end{array}$ & 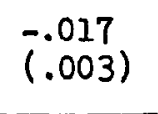 & $\begin{array}{l}-.028 \\
(.003)\end{array}$ & $-.008)$ & -.01 & .398 \\
\hline
\end{tabular}

SOURCE: Federal Reserve Bulletin (February issues, 1949-66)

- Standard errops of the coefficients shown in parentheses. Statistics for the average denomination represent monthly changes (in cents). Those for the separate denominations represent percentage. monthly changes in distribution ratios. 
Fig. 4 --Seasonal coefficients for the average denomination of paper currency, January 1948-December 1965 (end-of-month values).

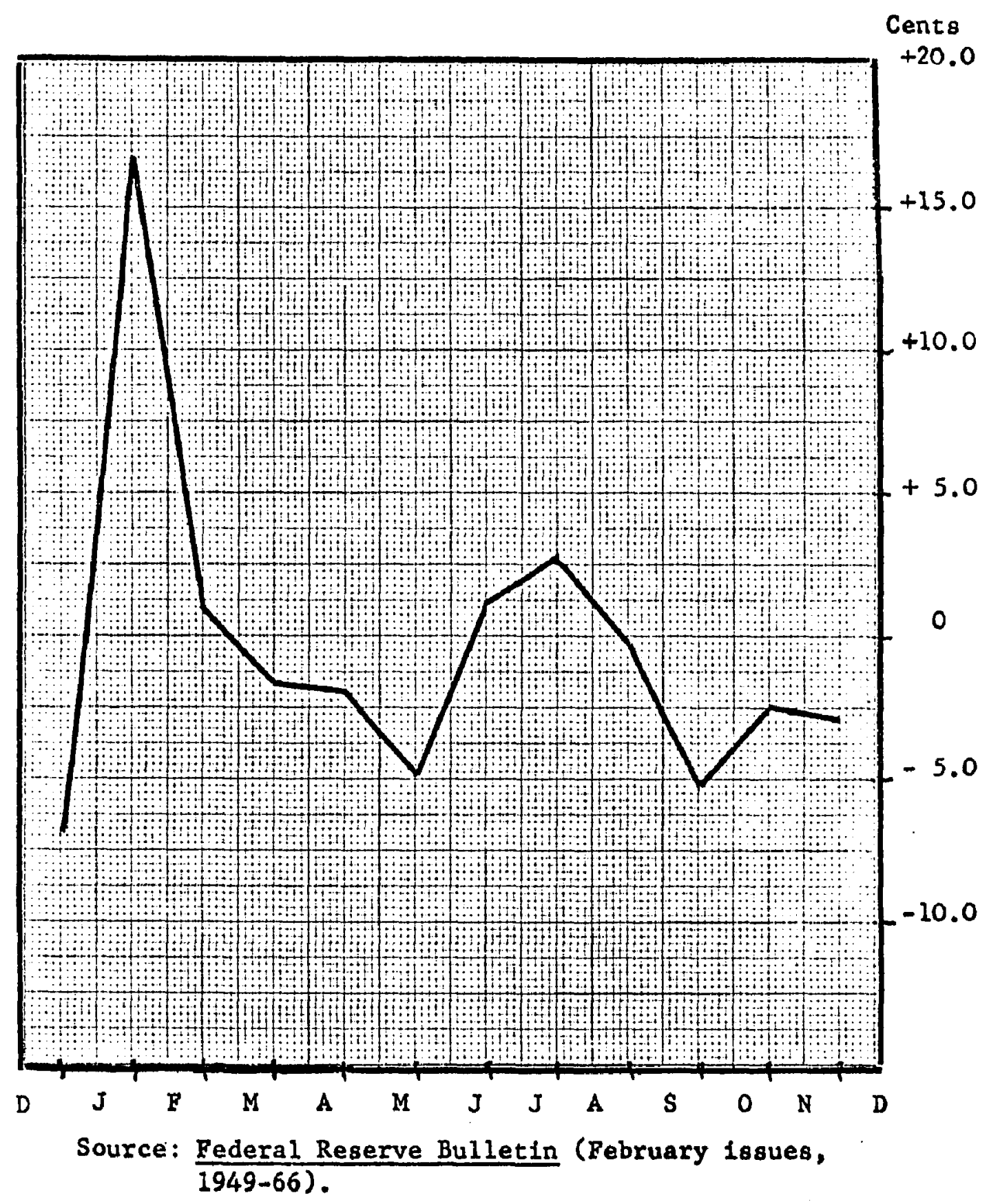


Fig. 5.--Seasonal coefficlents for small currency denominations, January 1948-December 1965 (end-of-month values).

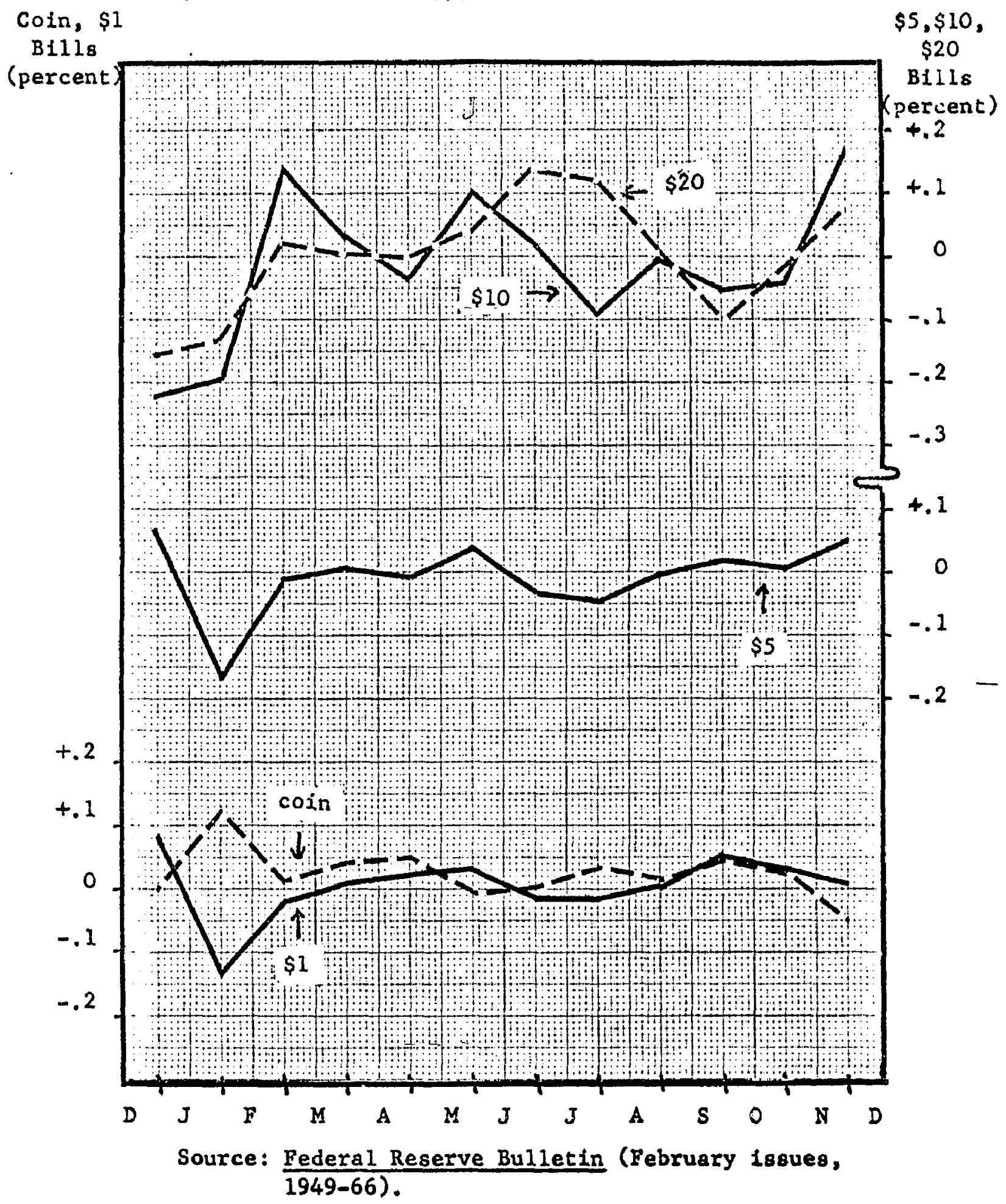


Fig. 6.--Seasonal coefficients for large currency denominations, January 1948-December 1965 (end-of-month values).

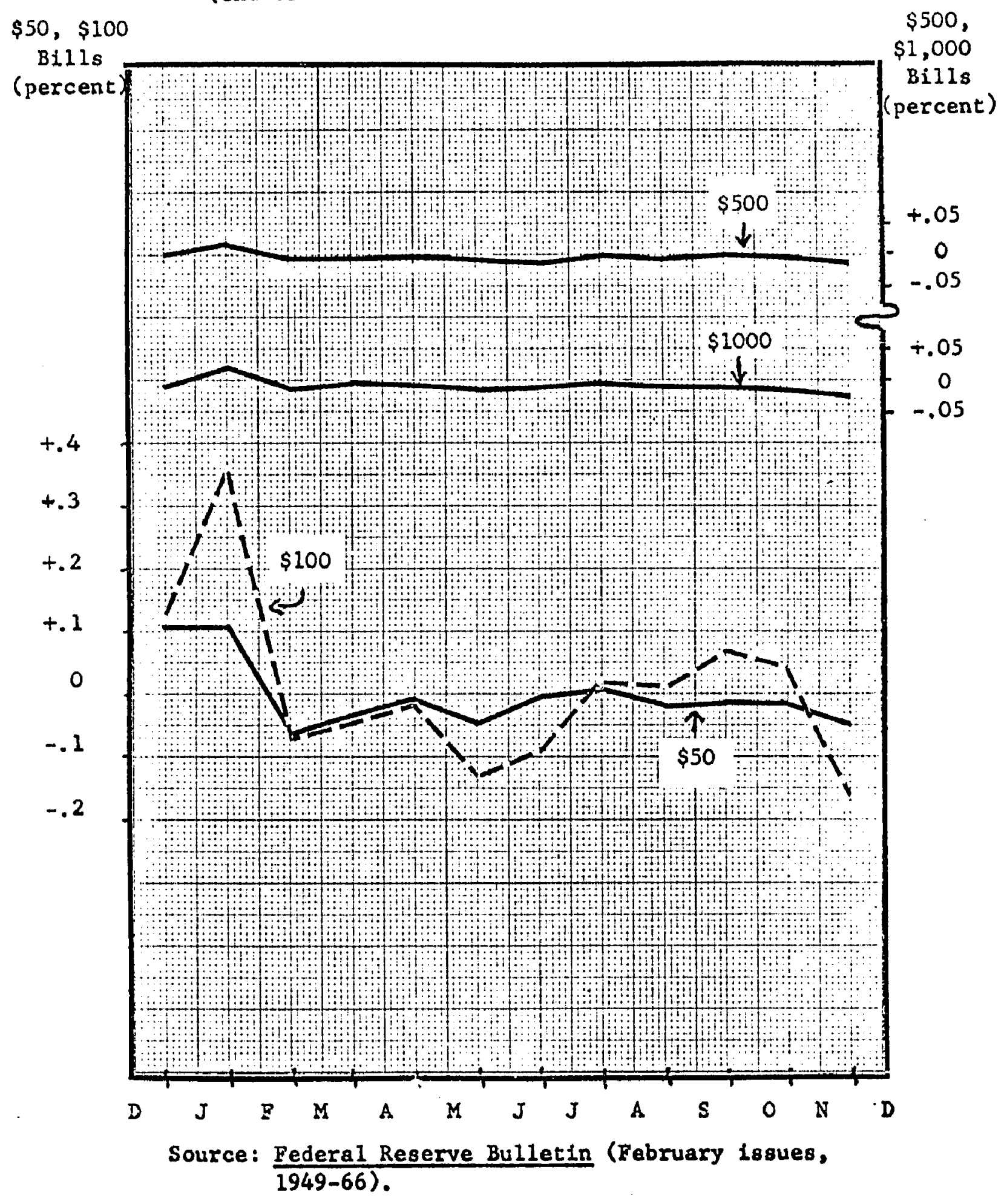


as proxies for quantitative (monthly) magnitudes. 4 Each of the coefficients for the months January through December should be contrasted with the annual average of monthly changes in the denomination in question ( see column 13 of Table 13).

The first and most important impression gained from an examination of the regression results is that seasonal influences on the distribution of denominations are quite strong, although the degree of "seasonality" varies greatly between denominations.5 More than 90 percent of the month-to-month variation in changes in the average denomination between 1948 and 1965 can be accounted for by the twelve dummy variables. 6 (See line 1 of Table 13). The standard error of estimate is $\$ .0197$, or only 0.2 percent of the mean. The standard errors for all of the monthly coefficients (except February and August) show these coefficients to be highly significant.

\footnotetext{
The form of the regression equation used to determine seasonal influences is as follows:$$
D_{i}=\alpha+\beta_{1} x_{1}+\beta_{2} x_{2}+\beta_{3} x_{3}+\ldots+\beta_{11} x_{11}
$$

where $D_{i}$ represents a given denomination (or grouping of denominations) expressed as a first difference; $x_{1}, x_{2}, \ldots x_{1}$, the dummy variables for each of eleven months, January through November; $\beta_{1}, \beta_{2}, \ldots \beta_{11}$, the coefficients which correspond to each of these months; and $\alpha$, a constant term reflecting the influence of December on the dependent variable. By re-running the equation and forcing the constant term to zero, the coefficient for the remaining month (December) is determined.

${ }^{5}$ The von Neuman test of autocorrelation was applied to each of the equations. With the exception of the one for $\$ 1000$ bills, none of the equations displayed significant autocorrelation at the .01 level of significance.
}

${ }^{6}$ Specifying the small denominations ratio (rather than the average denomination) as the dependent variable reduces the coefficient of determination slightly (to .865). Eight of the twelve monthly coeffients are statistically significant (see line 2, Table 13). 
Seasonal patterns vary widely among individual denominations. The coefficients of determination suggest that fairly strong seasonal patterns show up in relative demands for coin (.543) and $\$ 1(.882), \$ 5$, $(.846), \$ 10(.796), \$ 20(.688), \$ 50(.872), \$ 100(.863), \$ 500(.749)$ and $\$ 1,000(.398)$ bills. (See lines 3-1l of Table 13). Eighty-one of the 108 monthly coefficients in these equations are statistically significant. The standard errors of estimate are quite low in relation to the means. 7

\section{(A) Seasonal Patterns in the Average Denomination}

Seasonal variation in the coefficients is as expected in view of our hypothesis that small denominations of currency are best suited to ordinary retail transactions, while large denominations of currency serve primarily as a means for storing wealth and for making large-valued payments. The findings suggest that a rise in the demand for currency for use in current transactions (relative to the total demand for currency) is accompanied by increased relative preferences for small denominations, while a fall in the demand for currency for current transactions (relative to the total demand for currency) is accompanied by increased relative demands for large denominations. ${ }^{8}$

7 The standard errors of estimate for these equations fall within the range 0.2 to 1.1 percent of the means.

${ }^{8}$ Economic series can, of course, show a wide variety of seasonal patterns. The following analysis focuses primarily upon the relationship between denominational holdings and sales in the retail trade area, which embraces such activities as general merchandise and apparel sales, transactions at eating and drinking places, etc., all of which show pronounced seasonal variation. (See M. A. Smith, "Seasonal Adjustment of Economic Time Series," Survey of Current Business, September, 1962 , pp. 26-28). Certain retail series have parallels at the production level. However, since the latter are handled primarily through the use of checks rather than currency, their effect on denominational holdings is less apparent. 
An examination of the coefficients for the average denomination (see Figure 4) helps to illustrate this point. The coefficient for the average denomination is lowest on December $31(-7.01)$ and highest on January $31(+16.67)$. The December findings suggest that during the Christmas holidays there is an increase in current transactions demands for currency (relative to total demands for currency) and that these needs are met primarily through the use of small bills. This tends to result in a decline (of \$.07) in the average denomination. In January, when transactions demands for currency decline relative to total demands for currency, there is relatively less need for small bills. As a result the average denomination tends to rise (by \$.IT).

Between January $3 I$ and December 31 the general tendency is a decline (in the average amount of $\$ .004$ ) in the average denomination. Interesting departures from this downward movement can be detected. The average denomination tends to increase (by \$.009) between January 31 and February 28. This is not surprising in view of the relatively low level of retail activity during February. The result should not be taken too seriously, however, since the February coefficient is statistically insignificant.

Between February 28 and May 31 the average denomination tends to fall off. Two general factors may account for this: Easter buying and retail transactions reflecting preparations for the summer months. The decrease from late February to late March (\$.016) and from late March to late April (\$.020) is significant and greater than the average monthly decline (of \$.004) for the year. This is as expected, in light of the 
greater relative transactions needs for currency during the Easter holidays. ${ }^{9}$. The decline in the average denomination between April 30 and May 31 is even greater $(\$ .049)$. This might suggest that purchases in preparation for the summer months involve somewhat greater needs for currency for transactions purposes than purchases associated with Easter.

A sudden reversal in the post-February decline in the average denomination occurs during the summer. From May 31 to June 30 the average rises by $\$ .012$. An even greater increase (of \$.027) occurs between June 30 and July 31 . This might be due to the lessened transactions needs for currency during the summer: retail sales activity slows down during June and July, and this is reflected in a reduction in relative demands for small denominations. The average denomination tends to fall off (by $\$ .004$ ) between July 31 and August 31 (possibly due to the general expansion in retail sales activity towards the end of the sumer). The August coefficient for the average denomination is statistically insignificant.

For the duration of the year the tendency is for a significant decline each month in the average denomination. In each case the decline is far in excess of the average monthly decline (of \$.004). This probably reflects the general acceleration of the pace of retail activity after August. The average tends to fall off rather sharply (by \$.051) between August 31 and September 30, possibly due to "back to school" sales and early retail purchases associated with the winter holidays.

\footnotetext{
9The coefficients for March $(-1.62)$ and April (-1.99) are roughiy equal, which is as expected in view of the fact that Easter occurred as early as March 25 and as late as April 22 between 1948 and 1965.
} 
The declines in the average between September 30 and October 31 (of \$.026) and between October $3 I$ and November 30 (of \$.029) are somewhat more moderate, but still far in excess of the average monthly decline. The fact that the drop in the average during October and November is less than that registered during September may suggest that transactions needs for currency are somewhat lower in the former period. With the approach of the holidays, however, the average denomination once more falls off quite sharply. The November 30-December 31 decline (of $\$ .07$ ) is the largest of the year. This is not unexpected, given the greatly increased transactions needs for currency during the Christmas holidays.

(B) Individual Denominations and "Seasonality"

As noted earlier, strong seasonal patterns can be detected in relative demands for all the denominations surveyed. These patterns are depicted in Figures 5 and 6.

It is instructive to examine the patterns in terms of our hypothesis that small bills are associated with ordinary retail transactions, while large bills are best suited to the storing of wealth and the making of large-valued payments. According to this hypothesis (and our empirical observations concerning the explanatory power of the equations), demands for coin, $\$ 1, \$ 5, \$ 10$ and $\$ 20$ bills should rise significantly with an increase in current transactions demands for currency (relative to total demands for currency) and fall significantly with a decrease in current transactions demands for currency (relative to total demands for currency). Demands for $\$ 50, \$ 100, \$ 500$ and $\$ 1000$ bills should display an opposite pattern. 
For the sake of exposition, the year may be divided into four subperiods which roughly coincide with major changes in the volume of retail activity: (1) December 31 through January 31, during which time retail activity is at a low point; (2) January 31 through May 31 , a period associated with generally high levels of retail activity due to Easter sales and preparations for the summer months; (3) May 31 through August 31, during which time there is a "summer lull" in retail activity; and (4) August 31 through December 31, a period associated with fairly vigorous retail activity occasioned by autumn sales and the winter holidays. 10 The actual seasonal behavior of certain denominations during ." these four subperiods may be contrasted with the expected behavior of these denominations during the same subperiods.

(I) Small Denominations: Coin, $\$ 1, \$ 5, \$ 10$, and $\$ 20$

As can be seen in Figure 5, the general tendency is an increase in relative holdings of all small denominations (except coin) over the course of the year. The timing of the increase in relative holdings of the two smallest bills is somewhat different from that of relative holdings of the two largest bills. Holdings of $\$ 1$ and $\$ 5$ bills tend to rise after January 31 and reach their highest levels on December 31. Holdings of $\$ 10$ and $\$ 20$ bills, on the other hand, tend to rise after December 31 and to reach their highest levels as early as November 30. Relative demands for coin rise sharply during January and tend to decline over the remainder of the year. The following section examines variations in the distribution of these denominations in specific subperiods.

${ }^{10}$ See Smith, 1oc. cit. 
Lines 3-7 of Table 13 show the monthly coefficients for the coin, $\$ 1, \$ 5, \$ 10$, and $\$ 20$ denominations. Seasonal patterns emerge when each set of coefficients is contrasted with its respective mean (equal to zero in ail cases). Although a number of these coefficients are statistically insignificant (which suggests that during these months certain denominational categories do not display significant seasonality), the evidence generally supports patterns which coincide with our expectations.

During the first subperiod (December 31 to January 31 ) relative holdings of all small denominations (except coin) decline significantly. The decline is 0.130 percent (for $\$ 1$ bills), 0.158 percent (for $\$ 5$ bills), 0.195 percent (for $\$ 10$ bills), and 0.130 percent (for $\$ 20$ bills). This result is as expected in view of the relatively low levels of retail activity during January. Relative demands for coin, on the other hand, increase significantly (by 0.119 percent), a point which does not appear to be consistent with the decline in retail activity.

The evidence for the second subperiod is somewhat fragmentary. Between January 31 and April 30 the monthly coefficients for $\$ 5$ and $\$ 20$ bills are shown to be statistically insignificant, which suggests that seasonal considerations do not play a significant role in the variation in holdings of these bills. Relative demands for $\$ 1$ bills decline significantly during February, but rise significantly in March and April. Statistically significant increases also occur in relative holdings of coin (between February 28 and April 30) and $\$ 10$ bills (between January 31 and March 31). These increases may reflect the general expansion in the volume of retail trade around Eastertime. 
Significant increases in relative holdings, of all small denominations (except coin) are registered between April 30 and May 31. This is consistent with earlier observations on the rise in retail trade activity (due to summer sales, preparations for the summer months, etc.) at this time. Relative holdings of $\$ 1$ bills rise by 0.031 percent, $\$ 5$ bills by 0.042 percent, $\$ 10$ bills by 0.094 percent and $\$ 20$ bills by 0.042 percent. Relative holdings of coin tend to fall off during this month, although the decline is statistically insignificant.

During the third subperiod the behavior of most of the statistically significant coefficients is consistent with our expectations. Relative holdings of most small denominations tend to fall off between May $3 I$ and August 31, probably reflecting the summer 1 lul in retail activity. The relative circulation of $\$ 1$ and $\$ 5$ bills declines by 0.015 and 0.028 percent, respectively, between May 31 and June 30. This is accompanied by an (unexpected) increase in relative holdings of the \$20 denomination (by 0.139 percent). . From June 30 to July 31 we observe significant declines in relative demands for $\$ 1$ bills (by 0.018 percent), $\$ 5$ bills (by 0.047 percent), $\$ 10$ bills (by 0.092 percent), and $\$ 20$ bills (by 0.116 percent). Over the same period relative holdings of coin increase unexpectedly (by 0.027 percent). The relative circulation of coin rises again between July 31 and August 31. None of the other coefficients for this month is statistically significant.

The behavior of relative demands for small denominations over the rest of the year generally reflects an acceleration in the pace of retail activity, particularly with the approsch of the winter holidays. Only in the case of the $\$ 5$ and $\$ 20$ denominations (between September 30 and 
October 31 ) and the $\$ 1$ denomination (between October 31 and November 30 ), and coin (between November 30 and December 3I) are seasonal considerations shown to be statistically insignificant.

Seasonal patterns in the $\$ 1$ and $\$ 5$ categories are as expected: relative holdings of $\$ 1$ bills increase (by $0.054^{\circ}$ percent) during September (possibly reflecting early autumn sales), show somewhat lesser gains (of 0.028 percent) in October, and then rise sharply once more (by 0.085 percent) in December. Relative demands for $\$ 5$ bills increase moderately (by 0.016 percent) in September, but show more substantial gains in November $(0.050$ percent $)$ and December $(0.066$ percent $)$. The evidence on both denominations clearly supports the case for greatly increased transactions needs for currency with the approach of the Christmas holidays.

The seasonel patterns in relative holdings of the remaining small denominations are more difficult to explain in terms of the expansion in retail activity. Relative demands for the $\$ 10$ and $\$ 20$ denominations do increase significantly (by 0.165 and 0.077 percent, respectively) between October 31 and November 30. During the other months in this subperiod, however, they show substantial declines. The relative circulation of coin increases significantly during September and October (by 0.038 and 0.023 percent, respectively), but declines over the rest of the year. 
In sum: evidence on seasonal patterns in relative holdings of small denominations of U.S. currency generally supports a strong link between these denominations and the volume of retail trade. The general tendency is for a rise in retail activity to be accompanied by an increase in these holdings and for a decline in retail activity to be accompanied by a decrease in these holdings. The more notable exceptions to this are the seasonal patterns in relative demanas for coin (which rise significantly during January and the summer months, and fall significantly toward year's end) and for $\$ 10$ and $\$ 20$ bills (which also fall late in the year). The failure of the coin component of the currency stock to behave in a manner consistent with our observations on variation in retail trade activity is not easily explained. The fact that the transport of coin involves certain special considerations (e.g., extra weight and bulk) may be of some importance. Then, too, there appears to be a somewhat weaker seasonal pattern in relative holdings of coin than in any of the other small denominations surveyed: the coefficient of determination for relative coin demands is only .543, as against .882 for $\$ 1$ bills, .846 for $\$ 5$ bills, .796 for $\$ 10$ bills, and .688 for $\$ 20$ bills. The failure of the $\$ 10$ and $\$ 20$ categories to increase in relative circulation during December is also difficult to explain, although it may be related to the increased use of credit cards and checking accounts to make small purchases (against which these bills might otherwise be held for payment). 
(2) Large Bills: $\$ 50, \$ 100, \$ 500$, and $\$ 1,000$

The general tendency is a decrease in relative holdings of $\$ 50$, $\$ 100, \$ 500$, and $\$ 1,000$ bills over the course of the year. Lines $8-11$ of Table 13 show the monthly coefficients for these denominations. The average monthly change in the coefficients is equal to zero. Forty of the forty-eight coefficients are shown to be statistically significant. The majority of the insignificant coefficients are found in the summer months.

During the first subperiod (December 31 to January 31) relative demands for $\$ 50, \$ 100, \$ 500$, and $\$ 1,000$ bills show significant gains (by $0.106,0.357,0.020$, and 0.021 percent, respectively). This is consistent with our expectations: during January, when retail sales activity is at a low level, individuals and businesses tend to keep a large part of their currency holdings in the form of larger bills. As transactions needs for currency rise relative to total needs for currency during the second subperiod, holdings of these denominations tend to aecline significantly. During February demands for $\$ 50, \$ 100$, $\$ 500$, and $\$ 1,000$ bills fall off significantly (by $0.052,0.071,0.004$, and 0.011 percent, respectively). The March declines in relative demands for $\$ 50, \$ 100$, and $\$ 500$ are all statistically significant and amount to $0.034,0.048$, and 0.003 percent, respectively; the decrease in relative holdings of $\$ 1,000$ bills is statistically insignificant. The relative circulation of these four bills continues to fall off in April, although only the decline in relative holdings of $\$ 500$ ( 0.004 percent) and $\$ 1,000$ bills ( 0.008 percent) are significant. Finally, during May, relative 
demands for each of these large bills once more fall off significantly. For reasons noted earlier, this may reflect early summer sales and the purchase of retail items for use during the summer months.

The evidence on changes in holdings of these denominations between May 31 and August 31 is rather disappointing, since many of the seasonal coefficients are statistically insignificant and, among those which are significant, none has the expected positive sign. This leads us to question the hypothesis that the decline in retail sales activity during the summer months induces a transfer of currency holdings from small to large denominational forms.

The general tendency is a decline in relative holdings of each of the large bills surveyed through November 30. Relative demands for the $\$ 50, \$ 500$, and $\$ 1,000$ denominations fall off significantly each month between August 31 and November 30. The relative circulation of $\$ 100$ bills rises significantly between August 31 and October 31 , but declines during November. With this single exception, it appears that the evidence on the distribution of the four large denominations is consistent with the observed rise in the volume of retail activity between August 31 and November 30 .

An interesting development occurs in December. The relative circulation of $\$ 500$ and $\$ 1,000$ bills continues to decline (although the drop in the former category is statistically insignificant). Relative holdings of $\$ 50$ and $\$ 100$ bills, on the other hand, show significant gains (of 0.105 and 0.116 percent, respectively). While it is difficult 
to justify these increases in terms of observed gains in the volume of retail activity at Christmastime, they may result from other holidayrelated phenomena such as currency gift-giving;, the payment of cash bonuses, etc. 


\section{CONCLUSION}

The distribution of denominations of currency, while not an important statistic in its own right, may be significant as a reflection of economic behavior patterns that are vital. These patterns emerge when changes in the average denomination of currency are linked to changes in those economic magnitudes which might be expected to affect the demand for money more generally. The present study examines these patterns in terms of variation in denominational holdings of U.S. currency over the period 1914 to 1965. At this point it may be instructive to summarize the conclusions of this study and to suggest certain implications which they might have for the theory of money.

With few exceptions, previous currency studies emphasize the total dollar volume, rather than the denominational composition, of currency holdings. The work of Cagan and de Leeuw is a case in point. A few of the relationships which their studies have shown to be significant are also shown to be significant in this paper. Cagan's suggestion that the ratio of currency to money (broadly defined) varies inversely with interest rates and directly with the percentage of personal income taxed is analogous to our own observations about the links between the average denomination and these variables. Similarly, there are parallels between our own work and that of de Ieeuw, particularly with regard to the argument that a significant lag exists in the adjustment of currency 
holdings. In addition, both Cagan and de Leeuw assign a key role to the level of income (or wealth). The present writer has not been able to determine the precise relationship between these variables and the distribution of denominations, although certain related variables (including the level of prices) have been shown to be significant. The fundamental difference between the work of Cagan and de Leeuw and the present study is not so much in the choice of explanatory variables (or in the hypothesized relationships between these variables and some measure of currency behavior). Rather, it is in the definition of the dependent variable. We have shown that the currency stock should not be regarded as a single homogeneous commodity, but as a stock of slightly differing assets, each of which performs somewhat different services in the payments process. The fact that Cagan, de Leeuw, and others do not make this distinction may be of some significance, since currency defined as a single homogeneous commodity may bear a somewhat different relationship to a given set of economic variables than currency defined as a bundle of imperfectly substitutable assets may bear to the same variables. An important possibility is that changes in these variables which alter the denominational composition of currency holdings quite drastically may, at the same time, have no effect upon the size of these holdings. The 1923-29 pexiod serves as an interesting example: although the total stock of U.S. currency was quite stable over this period, the distribution of denominations of U.S. currency changed substantially. An approach which concentrates on movements in the total currency stock and ignores changes in the composition of this stock quite 
possibly obscures a number of interesting aspects of currency behavior. Denominational adjustments during the second half of the 1920's may reflect a pronounced rise in relative demands for currency for use in current transactions (due, in part, to movements in prices and interest rates over this period). However, if we take the total currency stock as the dependent variable (and assume, as many students of money do, that a significant link exists between such variables as prices and interest rates, on the one hand, and the currency stock on the other) trends in these explanatory variables over some relatively short period of time (e.g., the Twenties) may prove inadequate as explanations of the behavior of the currency stock.

It is also possible that our findings have some implications for the definition of money. If units of deposit money are (like units of currency) non-homogeneous, it may mean that even very narrow money concepts involve adding together quite different magnitudes. In this regard, the traditional definition of money "as anything that is generally acceptable as a means of payment" may be inadequate, since it ignores the possibility that, in some given period, a fraction of the money stock may not actually be used as a means of payment, but may be stored against future payments. Just as the absence of change in the total currency $_{\rho_{1}}$ stock may conceal rather drastic changes in the distribution a of denominations of currency, so too the absence of change in currency . plus demand deposits may conceal important changes in their underlying components. A more meaningful definition of the money stock would distinguish between those components used for current transactions and 
those components stored against future payments. The latter might be more properly grouped with savings deposits.

The possible importance of the denominational approach has been noted by many students of money, but, so far as, can be determined, Klein is the only writer who has examined denominational demands in any detail. The scope of kein's work is, at least in one regard, somewhat broader than that of the present study: in addition to movements in the average denomination of currency Klein also considers the behavior of the average denomination of net checks handled by the Federal Reserve. The emphasis in the Klein study is upon annual price-average denomination relationships over the period 1934 to 1958 (for currency) and 1939 to 1958 (for checking accounts). Variation in denominational holdings which he is unable to trace to price movements are explained in terms of changes in income distribution, the volume of installment credit, and preferences for checking accounts. For reasons noted in Chapter I, this may be an unfortunate choice of explanatory variables, since (at least with regard to the influence of the income distribution and credit variables) a priori judgments are very difficult. Unfortunately, Klein offers very little empirical evidence in support of his hypothesis that the average denomination of currency and of checks would fall with a movement toward greater equality in the distribution of income or increased use of installment credit. Nor, for that matter, does he consider the possibility that there are also theoretical grounds for expecting a direct relationship between the average denomination and these variables.

Our findings suggest that the links between the distribution of denominations and the economic environment are far more complex than 
Klein's analysis would imply. We have shown that these links define a demand relationship, which (at least prior to the Sixties) can be regarded as wholly independent of supply considerations. We have attempted to provide a broad historical analysis of denominational behavior over the period 1914 to 1965 and have constructed demand estimates which describe certain secular and seasonal patterns. These estimates provide broad. empirical support for generalizations concerning the conditions under which one might expect to observe a change in the distribution of denominations. The secular evidence suggests that a rise in the average denomination of currency might be associated with an increase in consumer prices and the percentage of personal income taxed and a decline in interest rates, the use of consumer credit facilities, and the deposit money ratio. There is reason to believe that the response to prices involves a lag of at least one year's duration. The seasonal evidence suggests that seasonal considerations may also play a significant role: the average denomination tends to rise significantly with a decline in retail trade activity (e.g., in January) and to fall significantly with an increase in this activity (e.g., in December). Strong seasonal patterns-can be detected in the coin and $\$ 1, \$ 5, \$ 10, \$ 20, \$ 50, \$ 100$, $\$ 500$ and $\$ 1000$ bill categories.

The present study represents a first step in the development of a comprehensive theory of denominational demands. Accordingly, it is perhaps appropriate to conclude by noting briefly what additional steps will be taken in developing this theory.

First, the basic model presented in Chapter I should be broadened --which may mean reworked--to include other variables which students of 
money have shown to be relevant to currency behavior. The present study has not been able to establish a conceptual basis for the role of income (or wealth) in denominational demands. This variable occupies a key role in the currency studies of Cagan, de Leeuw, and others. Once we have established the link between income (or wealth) and the distribution of denominations, it may be possible to identify separate price and income influences on denominational holdings. A useful first step in this direction might involve empirical tests of the relationship between these holdings and the distribution of income.

The possible relevance of other variables should also be explored. Previous studies of currency behavior tend to assign some importance to the matter of urbanization and population mobility. If these factors play a major role in determining the size of currency holdings, they may also be significant with regard to the denominational composition of these holdings. Future research might also uncover other important variables.

Further attention should also be given to the statistical problems involved in developing estimates of denominational demands. There is reason to believe that biases due to multicollinearity and/or serial correlation might be present in our regression results. In addition, it may be usefur to consider redefining certain of the variables, particularly those for which it is difficult to make a priori generalizations (e.g., consumer credit).

It is unfortunate that the model presented here lacks an analysis of the costs of making asset transactions. The fact that "transactions costs" are not easily quantified does not mean that certain theoretical 
generalizations about these costs cannot be made. Such generalizations might involve the value of the time spent in acquiring a desired denomination or utilizing the non-pecuniary services of this denomination, the costs of storing the denomination prior to its use in making payments, and other factors which are relevant to the acquisition, holding, and expenditure of currency assets. These considerations might then be incorporated into a model similar to those developed by Baumol and Tobin.

The possibility of reworking the basic model presented in Chapter I to include the average denomination of checks also deserves further investigation. As an empirical matter there are certain limits on this approach, since information on checks cleared through the Federal Reserve Banks is not available prior to 1939. However, the analysis of denominational demands will remain incomplete so long as the behavior of the distribution of denominations of checks is ignored.

Finally, the basic model (or some variant of it) might profitably . be tested using denominational statistics from other countries. As noted in Appendix C such statistics are particularly well-suited to studies of long-term currency behavior, since most of them extend far back into the 19th century. An application of the model to other countries might provide additional insights into relationships discussed in the present study. 
APPENDIX A

Estimaticn of Denominations in Circulation, 1914-33

As noted earlier, monthly statistics on the actual circulation of currency are not available until October, 1930, for small denominations, and May, 1933 for large ones. This series, known officially as "currency in circulation", excludes all currency and coin held by the Federal Reserve Banks, the U.S. Treasury Department, and mints and assay offices. Earlier data include holdings by the monetary authorities and are published on an annual basis only (as of June 30). The latter series (known officially as "currency outstanding") is inconsistent in its published form with the former series, since it overstates the demand for currency denominations by the amount of holdings by the Treasury and Federal Reserve. The techniques used to convert "outstanding" data into "in circulation" data for the years. 1914-33 are described below.

First, the "average" share of each denomination held by the monetary authorities was estimated for the period 1914-33. This 
TABLE 14

VALUE OF DENOMINATIONAL HOLDINGS BY MONETARY AUTHORITIES AS A PERCENTAGE OF TOTAL PAPER CURRENCY OUTSTANDING, 1931, 1945-48*

\begin{tabular}{cccccccc}
\hline Year & $\begin{array}{c}\text { AlI Small } \\
\text { Paper Denom- } \\
\text { inations } \\
(\$ 1-\$ 20)\end{array}$ & $\$ 1$ & $\$ 2$ & $\$ 5$ & $\$ 10$ & $\$ 20$ & $\begin{array}{c}\text { All Large } \\
\text { Denominations } \\
(\$ 50-\$ 10,000)\end{array}$ \\
\hline 1931 & 22.7 & 23.5 & 26.4 & 17.8 & 23.0 & 24.6 & 26.1 \\
1945 & 4.1 & 16.7 & 18.0 & 5.1 & 3.2 & 2.6 & 3.3 \\
1946 & 4.6 & 15.4 & 18.3 & 8.3 & 3.7 & 2.9 & 2.6 \\
1947 & 4.1 & 13.0 & 17.9 & 6.0 & 3.8 & 2.7 & 2.4 \\
1948 & 4.9 & 13.6 & 17.1 & 8.1 & 4.4 & 3.2 & 2.7 \\
\hline
\end{tabular}

SOURCE: U.S. Treasury Department, Annual Reports, 1931, 1945-48.

* Values as of June 30 . 
involved an extrapolation of their 1931 holdings back to 1914.1 Values for each of the following terms were found as of June 30, 1931:

$$
\begin{aligned}
& \mathrm{CO}_{i}: \text { currency outstanding in denomination "i" } \\
& \mathrm{CC}_{i}: \text { currency in circulation in denomination "i" } \\
& \mathrm{D}_{i}: \mathrm{CO}_{i}-\mathrm{CC}_{i} \\
& \sum\left(\mathrm{CO}_{i}\right): \text { total currency outstanding } \\
& \sum\left(\mathrm{CC}_{i}\right): \text { total currency in circulation } \\
& \sum\left(\mathrm{D}_{i}\right): \sum\left(\mathrm{CO}_{i}\right)-\sum\left(\mathrm{CC}_{i}\right)
\end{aligned}
$$

Each denominational difference $\left(D_{i}\right)$ was then expressed as a percentage of the total difference $\left[\xi\left(D_{i}\right)\right]$ between total currency outstanding and total currency in circulation $\left[=D_{i} / \sum\left(D_{i}\right)\right]$. These percentages were extrapolated back to 1914. For year " $t$ " the estimated difference between

IThe choice of 1931 data as the basis for the extrapolation (rather than data for a longer period) requires explanation. Information on the dollar amount of holdings of each denomination by the monetary authorities is available only for 1931 and the period 1945-65. In Table 14, we show the value of these holdings as a percentage of total paper currency outstanding for the years 1931 and 1945-48. As can be seen from this table, the monetary authorities held a larger share of currency in 1931 in all denominational categories than they did in the immediate postwar period. (Although post-1948 values are not shown in this table, they are not significantly different from those between 1945 and 1948). This suggests that their attitudes towards the "proper" share of holdings were substantially revised between 1931 and 1945 .

We suggest that the 1931 holdings might be more representative of those between 1914 and 1933 than those in the postwar period. Although the evidence is far from conclusive, there is reason to believe that in the early years of the Federal Reserve there was a purposeful attempt to "overstock" denominations. With improvements in the currency supply process and in forecasting techniques, the need for overstocking denominations has been reduced. At no time since 1945 have the monetary authorities found it necessary to have bills in excess of $\$ 100$ printed. 
currency outstanding and currency in circulation in denomination "i" $\left[\left(\hat{D}_{i}\right)_{t}\right]$ was :

$$
\left[D_{i} / \sum\left(D_{i}\right)\right]_{1931}\left[\sum\left(D_{i}\right)_{t}\right]=\left(\hat{D_{i}}\right)_{t}
$$

where $\left[\sum\left(D_{i}\right)_{t}\right]$ represents the total actual difference between currency outstanding and currency in circulation in year " $t$ ". The estimated denominational difference was then subtracted from the actual amount of each denomination outstanding in year " $t$ ":

$$
\sum\left(\mathrm{Co}_{i}\right)_{t}-\hat{\left(\mathrm{D}_{i}\right)_{t}}=\hat{\mathrm{CC}}_{i t}
$$

The residual $\left(\widehat{C C}_{i t}\right)$ represents our estimate of the amount of currency in denomination " $i$ " in circulation in year " $t$ ". . 


\section{APPENDIX B}

\section{The Supply of Denominations of Currency}

in the U.S., 1914-65

A familiar problem in empirical studies of aggregate behavior is that of the interaction between supply and demand functions, rendering difficult the separate analysis of either one of them. In terms of the current study we must determine whether or not the supply of denominations of currency in the United States has been sufficiently "elastic" to satisfy the demands which holders of currency have placed upon it. Were this not the case (i.e., were it true that currency demands were constrained by the reluctance and/or inability of the monetary authorities to make desired denominations available), serious identification problems might result. Alternatively, if we can establish that throughout the period 1914-65 the supply of denominations was fully responsive to changes in currency demands, it is then possible to analyse the demand for denominations as an independent function. Evidence in support of this latter point is offered in this section.

\section{(A) Paper Currency}

The mechanics of the supply process vis-a-vis paper currency and coin are quite simple. Assume, for example, that a commercial bank finds that its vaults are insufficiently stocked with $\$ 20$ bills to meet public demands for this denomination. It can obtain these bills from two 
different sources: (I) accommodation through intra-district banking arrangements; and (2) accommodation through direct contact with its Federal Reserve Bank. In view of the inconvenience and cost involved in transporting currency and coin, the Federal Reserve encourages the first type of accommodation. ${ }^{2}$ In this case, the commercial bank would file a request for $\$ 20$ bills with a nearby bank having an excess supply of this denomination. If the latter bank is willing to meet such demands, the former can avoid paying the higher transport costs that would be involved in direct shipments from the Federal Reserve. ${ }^{2}$

The second and more important source of currency supply is the Federal Reserve Bank serving the commercial bank's district. The stated policy of the Federal Reserve is

to supply its member banks with United States currency and coin in such amounts as may be needed and in such denominations as may be qvailable. ${ }^{3}$ (italics added)

For this purpose all Federal Reserve Banks maintain a "currency and coin service," the costs of which are borne by banks which make requests for currency. Subscribers to this service are informed through Bank letters of the procedures for currency withdrawals. While formal written requests

${ }^{1}$ See, for example, Federal Reserve Bank of Boston, Operating Letter No. 5, April 1, 1954.

2The reasons why Federal Reserve Banks prefer this type of accommodation are spelled out in an operating. letter of the Federal Reserve Bank of Boston. The Bank's preference for inter-(commercial) bank accommodation is "not intended to imply any limitation whatever upon the use of (the currency and coin) service by any bank having a need therefor, but to encourage the adoption of practices whereby it is believed that movements of money to or from this bank can be aroided, in some instances at least, without disadvantage or inconvenience." (See ibia., p. 1).

${ }^{3}$ Ibid. 
are encouraged, a number of less formal arrangements can be used. For example, should the bank needing $\$ 20$ denominations require these bills immediately, it can avoid the extra delay involved in mailing its order by making a telephonic or telegraphic request from the Federal Reserve. Requests for currency or coin are usuelly filled on the same day as received, so long as they arrive at the Federal Reserve before its vaults are closed. These requests need not be made in "standard units" (e.g., \$20 bills in lots of 100 units), although the Bank encourages such a procedure. For these reasons, it is entirely possible that a commercial bank, facing an emergency drain on its inventory of $\$ 20$ bills, will be able to replenish this stock within the matter of 24 hours. Ultimate responsibility for the issuance of U.S. paper currency and Federal Reserve notes rests with the U.S. Treasury and Federal Reserve Banks, respectively. The Treasurer's Office procures all Treasury currency from the Bureau of Printing and Engraving and places it in circulation as needed, primarily through the Federal Reserve Banks. The Federal Reserve Banks (acting through their agents) are also supplied with currency by the Bureau, and hold a large inventory of all denominations in anticipation of commercial bank demands. The highest denomination printed by the Bureau since 1945 is the $\$ 100$ Federal Reserve Note. Their inventories of $\$ 500, \$ 1,000, \$ 5,000$ and $\$ 10,000$ bills have been sufficiently large to accommodate the demands of the Federal Reserve Banks without additional printing of these denominations. 
- Additionally, the Federal Reserve has primary responsibjlity for the redemption and destruction of both U.S. currency and its own notes, 4 as they become unfit for circulation. 5 The standards applied to the "fitness" of currency may be altered by the monetary authority. This fact may have some relevance for their ability to supply particular denominations.

\section{(B) Coin}

The mechanics of the coin and currency supply processes differ in only one respect: it is the Bureau of the Mint, rather than the Bureau of Printing and Engraving, which accommodates the coin demands of the monetary authority. This agency issues coins for general circulation to the Federal Reserve Banks and the Office of the Treasurer, which in turn deliver the coins to commercial banks upon request.

We have attempted to establish the case for an "elastic" currency and coin supply using two approaches. In the first place, letters were written to the Currency Officers of each of the twelve Federal Reserve Banks. (See copy of letter, p. 140). We asked whether or not the Banks were fully able to accommodate the denominational demands of the public in the period 1914-65. Their replies offer strong evidence for a highly flexible denominations supply, with one exception: the

\footnotetext{
${ }^{4} \mathrm{~A}$ small amount of currency is redeemed directly by the Treasurer's Office.

${ }^{5}$ Redemption involves cutting the notes in half and forwarding the halves separately to Washington. The Office of the Comptroller of the Currency then verifies the upper halves and the Currency Redemption Division of the Treasurer's Office the lower halves. A special committee supervises their destruction.
} 
now-familiar "coin shortage" of the 1960's. Since 1961 acute coin shortages have developed in various parts of the country, making it necessary for the Federal Reserve Banks to ration all coin denominations to member banks. In order to meet these demands for coins, the monetary authority has urged a number of improvements in the minting procedures. ${ }^{6}$ These improvements have enabled the Mint to increase its overall productivity substantially, but it still cannot fully meet the requirements of the monetary authority. Furthermore, the Mints have been unable to maintain even modest inventories of coins in their own vaults. While this situation provides a dramatic example of inflexibility in the coin supply process, it must be regarded as an exceptional case. Upon the basis of correspondence received from the Federal Reserve Banks, we must conclude that there is strong support for the argument that the supply of currency and coin denominations has been highly elastic since 1914.

As additional, proof we present data on the "Net Production and Inventories of Denominations of U.S. Currency in Relation to Changes in Amounts in Circulation, June 30, 1949 - June 30, 1964."7 (See Table 15, p. 141). Line 1 of each annual grouping shows the changes in each of eleven denominations demanded during the fiscal year. Lines 2 and 3 depict the supply variables. In line 2 we show the inventories of these

${ }^{6}$ Included among these are the extension of the work week, the introduction of new machinery, and the erection of a new coinage mint in Philadelphia to replace the existing building there. Philadelphia was chosen over other locations because about 70 percent of all coins manufactured are delivered to banks nearest to Philadelphia.

${ }^{7}$ This period was chosen because denominational data on net production and inventories is not available prior to 1949. 
denominations held by both the Treasury and Federal Reserve at the beginning of the fiscal year. Line 3 depicts the net production of these denominations over the course of the fiscal year (i.e., the difference between the dollar amount of redemptions and issues, by denomination). With few exceptions, the monetary authority maintained an inventory of denominations which was sufficient to meet annual public demands. Its stock of all denominations was extremely stable, despite substantial changes in the holdings of currency. The authority's ability to satisfy circulation needs out of current inventories is most apparent in the lowest and highest denominational categories (i.e., \$1, \$2, \$5, \$10, $\$ 500, \$ 1,000, \$ 5,000$ and $\$ 10,000)$. In each of these denominational categories annual changes in demand were less than the stock of inventories at the beginning of the fiscal year.

The exceptions occur in the $\$ 20, \$ 50$ and $\$ 100$ categories for the years 1951-53, 1959 and 1963-64. In these years the stock of inventories was not sufficient to meet current needs and this caused the monetary authorities to make unusual demands on the Bureau of Printing and Engraving. In each case the rate. of issue was stepped up or the rate of redemptions reduced to accommodate public demands. 8 The evidence on the currency supply process therefore suggests that the monetary authority has been able to satisfy public

${ }^{8}$ In most instances the net production figure exceeded the annual circulation change, indicating a tendency for the monetary authorities to occasionally over-fulfill current needs. This tendency to "overstock" denominations was apparent, for example, in 1952, when net production of $\$ 20, \$ 50$, and $\$ 100$ bills exceeded circulation changes in each category by more than five million dollars. 
requirements for particular denominations in all but a few instances. It has done this through "over-stocking" its own holdings of the various denominations (i.e., through carrying an amount of each denomination in excess of forecasted needs). The inability of the monetary authority to satisfy public demands for certain denominations of coin during the 1960 's is a rather dramatic (but unusual) case of supply inelasticity. In addition, strikes at mints and temporary shortages of printing materials may have resulted in occasional delays in the delivery of currency to banks. Further research might be directed to a consideration of the relationship between strikes, paper shortages, and other problems and the timing of the currency supply process, in order to discover whether these problems substantially affect the degree of supply elasticity. 
Copy of Letter to Federal Reserve Banks

Director

Currency Department

Federal Reserve Bank

\section{Dear Sir:}

I wonder if you might be able to answer a few questions concerning my current research on the denominations of U.S. currency, 1914-65. This research is being done in connection with a Ph.D. dissertation which I am writing in Economics at The Ohio State University.

At present I am trying to determine whether or not there was ever a time when the public was not able to obtain the exact denominations of currency which it desired. More specifically, I am attempting to establish whether or not the supply of all denominations over the period 1914-65 varied in direct response to changes in the demands for these denominations.

Having surveyed a large number of Federal Reserve publications, I find that there is little written evidence to establish this point one way or the other. I wonder if you could supply answers to the following questions:

(I) Where might I find a discussion of the mechanics of the currency supply process vis-a-vis currency denominations?

(2) To your knowledge has there ever been a time when the Federal Reserve Bank of was unable to supply particular denominations to commercial banks upon request?

(3) In such situations what was the approximate length of time required in meeting bank demands for these denominations?

Your help in answering these questions will be greatly appreciated. Sincerely yours, 
TABLE 15

NET PRODUCTION AND INVENTORIES OF CURRENCY DENOMINATIONS IN RELATION TO CHAINGES IN AMOUNTS IN CIRCUIATION, JUNE 30, 1949 - JUNE 30, $1965^{\circ}$ (Millions of Dollars)

\begin{tabular}{|c|c|c|c|c|c|c|c|c|c|c|c|}
\hline & $\$ 1$ & $\$ 2$ & $\$ 5$ & $\$ 10$ & $\$ 20$ & $\$ 50$ & $\$ 100$ & $\$ 500$ & $\$ 1000$ & $\$ 5000$ & $\$ 10000$ \\
\hline \multicolumn{12}{|l|}{1949} \\
\hline Circulation Change & +8 & -2 & -46 & -154 & -.186 & -39 & +29 & -20 & -37 & 0 & -1 \\
\hline Inventory & $\mathbf{b}$ & $\mathrm{b}$ & $\mathrm{b}$ & $\mathrm{b}$ & $\mathbf{b}$ & $\mathrm{b}$ & $b$ & $\mathrm{~b}$ & $b$ & $\mathbf{b}$ & $\mathbf{b}$ \\
\hline Net Production & +19.3 & -1.3 & -67.2 & -195.4 & -202.7 & -37.3 & +39.5 & -22.0 & -41.2 & -.3 & -2.3 \\
\hline \multicolumn{12}{|l|}{1950} \\
\hline Circulation Change & +29 & 0 & -5 & -40 & -188 & -40 & -34 & -9 & -84 & -1 & 0 \\
\hline Inventory & 168.7 & 13.1 & 156.8 & 239.6 & $27 J . .4$ & 71.6 & 103.6 & 15.5 & 35.1 & 2.9 & 12.5 \\
\hline Net Production & -18.0 & -.3 & -31.5 & -22.6 & -199.3 & -45.0 & -28.5 & -5.5 & -76.5 & -.5 & -2.1 \\
\hline \multicolumn{12}{|l|}{1951} \\
\hline Circulation Change & +55 & +3 & +45 & +222 & +300 & +19 & +7 & -22 & -58 & 0 & -1 \\
\hline Inventory & 122.4 & 3.3 .4 & 130.9 & 256.7 & 259.8 & 66.8 & 109.8 & $19: 2$ & 43.2 & 2.6 & 10.3 \\
\hline Net Production & +150.2 & +2.2 & +117.9 & +337.4 & +386.6 & +33.1 & +8.8 & -19.9 & -62.7 & -.1 & -.1 \\
\hline
\end{tabular}

SOURCE: Annual Reports of U.S. Treasury, 1949-65; Federal Reserve Bulletin (February issues), $1950-66$.

a Circulation change and net production figures represent changes over course of entire fiscal. year; inventories held by Federal Reserve and Treasury given for beginning of fiscal year.

bot avajlable. 
TABIE 15 (cont.)

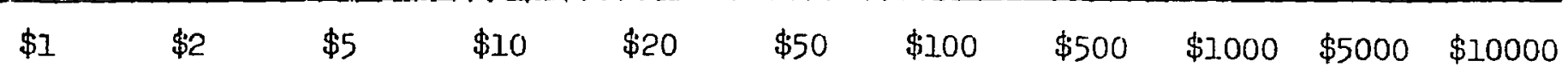

\begin{tabular}{|c|c|c|c|c|c|c|c|c|c|c|c|}
\hline 1952 & & & & & & & & & & & \\
\hline Circulation Change & +48 & +4 & +43 & +210 & +524 & +126 & +219 & -12 & -45 & 0 & 0 \\
\hline Inventory & 217.2 & 12.5 & 203.3 & 372.0 & 346.8 & 80.7 & 111.6 & 21.2 & 38.3 & 3.0 & 11.2 \\
\hline $\begin{array}{c}\text { Net Production } \\
1953\end{array}$ & +66.0 & +4.7 & +29.4 & +211.4 & +531.3 & +139.8 & +234.5 & -12.6 & -43.3 & +.5 & +.3 \\
\hline Circulation Change & +36 & +1 & +17 & +204 & +448 & +114 & +225 & -7 & -26 & 0 & 0 \\
\hline Inventory & 235.2 & 12.7 & 190.3 & 373.4 & 354.5 & 95.0 & 127.1 & 20.3 & 39.6 & 3.7 & 11.2 \\
\hline Net Production & +30.7 & +3.1 & -4.2 & +204.7 & +456.3 & +104.8 & +207.8 & -15.9 & -40.3 & -.8 & -.1 \\
\hline \multicolumn{12}{|l|}{1954} \\
\hline Circulation Change & +7 & \pm 2 &. .48 & -150 & -84 & +14 & +66 & -13 & -26 & 0 & 0 \\
\hline Invent ory & 229.9 & 15.0 & 168.6 & 374.6 & 362.8 & 86.0 & 109.6 & 12.1 & 25.6 & 3.0 & 11.1 \\
\hline $\begin{array}{c}\text { Net Production } \\
\underline{1955}\end{array}$ & \multicolumn{2}{|c|}{1955} & $-41: 4$ & -134.2 & -37.3 & +18.1 & +78.0 & -14.7 & -32.1 & -.3 & -.4 \\
\hline Circulation Change & +43 & +1 & +38 & +94 & +74 & -1 & +30 & -12 & -25 & -1 & +1 \\
\hline Inventory & 223.9 & 1.3 .3 & 175.1 & 390.0 & 409.6 & 89.9 & $12] .6$ & 10.0 & 19.3 & 2.8 & 11.2 \\
\hline Net Production & +28.4 & +4.3 & +28.3 & +28.8 & -7.2 & -3.5 & +33.4 & -10.5 & -20.3 & +.1 & +.7 \\
\hline
\end{tabular}




\begin{tabular}{|c|c|c|c|c|c|c|c|c|c|c|c|}
\hline & $\$ 1$ & $\$ 2$ & $\$$ & $\$ 10$ & $\$ E 0$ & $\$ 50$ & $\$ 100$ & $\$ 500$ & $\$ 1000$ & $\$ 5000$ & $\$ 10000$ \\
\hline \multicolumn{12}{|l|}{1956} \\
\hline Circulation Change & +36 & +2 & +29 & +118 & +213 & +18 & +18 & -16 & -27 & 0 & +4 \\
\hline Inventory & 209.3 & 16.4 & 165.9 & 324.5 & 327.7 & 87.2 & 125.0 & 11.6 & 23.3 & 3.0 & 10.5 \\
\hline Net Production & +54.4 & +1.2 & +63.2 & +156.8 & +258.2 & +20.3 & +16.6 & -16.9 & -26.2 & -.5 & +3.8 \\
\hline \multicolumn{12}{|l|}{1957} \\
\hline Circulation Change & +40 & +13 & +12 & +26 & +147 & +20 & +70 & -.13 & -30 & 0 & -3 \\
\hline Inventory & 227.5 & 15.0 & 199.9 & 363.6 & 372.9 & 89.2 & 123.5 & 10.1 & 25.1 & 2.7 & 10.4 \\
\hline Net Production & +37.0 & +2.5 & -22.6 & +118.3 & +209.5 & +37.6 & +87.9 & $-13 \cdot 3$ & -27.8 & -.2 & -3.2 \\
\hline \multicolumn{12}{|l|}{1958} \\
\hline Circulation Change & +66 & +4 & -21 & -126 & +34 & +5 & +94 & -8 & -14 & 0 & -1 \\
\hline Inventory & 223.9 & 14.8 & 165.4 & 455.3 & 435.7 & 1.07 .0 & 140.7 & 10.0 & 26.5 & 2.6 & 10.6 \\
\hline Net Production & +39.7 & +3.5 & -1.2 & -204.7 & -25.1 & +7.2 & +76.2 & $-7 \cdot 3$ & -14.7 & +.1 & -1.1 \\
\hline \multicolumn{12}{|l|}{1959} \\
\hline Circulation Changs & +31 & +2 & +36 & +95 & +263 & +41 & +139 & -10 & -20 & 0 & $-]$ \\
\hline Inventor: & 197.9 & 14.4 & 185.5 & 377.4 & 376.3 & 109.4 & 123.5 & 12.2 & 26.0 & 2.4 & 10.6 \\
\hline Net Production & +128.5 & +1.4 & +28.2 & +.241 .6 & +273.5 & +38.4 & +164.6 & +3.9 & -18.8 & +.5 & $-1 \cdot 3$ \\
\hline
\end{tabular}


TABLE 15 (cont.)

\begin{tabular}{|c|c|c|c|c|c|c|c|c|c|c|c|}
\hline 6 & $\$ 1$ & $\$ 2$ & $\$ 5$ & $\$ 10$ & $\$ 20$ & $\$ 50$ & $\$ 100$ & $\$ 500$ & $\$ 1000$ & $\$ 5000$ & $\$ 10000$ \\
\hline \multicolumn{12}{|l|}{1960} \\
\hline Circulation Change & -9 & +1 & +24 & +20 & +81 & -5 & -34 & -13 & -34 & 0 & -3 \\
\hline Inventory & 245.7 & 13.9 & 176.9 & 423.4 & 386.4 & 106.9 & 148.6 & 24.3 & 27.2 & 3.2 & 10.2 \\
\hline Net Production & +4.6 & +1.2 & +18.8 & -15.2 & +146.7 & +8.7 & -31.9 & -18.0 & -26.8 & -.3 & -1.1 \\
\hline \multicolumn{12}{|l|}{1961} \\
\hline Circulation Change & +22 & +4 & +21 & +34 & +55 & +20 & +87 & -9 & -17 & 0 & 0 \\
\hline Inventory & 259.6 & 14.2 & 172.3 & 388.5 & 452.5 & 120.2 & 150.8 & 20.0 & 34.4 & 2.7 & 11.3 \\
\hline Net Production & +18.8 & +3.9 & +73.2 & +200.7 & +161.6 & +11.3 & +82.0 & -11.0 & -14.8 & -.4 & +.2 \\
\hline 1962 & & & & & & & & & & $\because$ & \\
\hline Circulation Change & +54 & +5 & +69 & +199 & +519 & +93 & +250 & -4 & -11 & 0 & 0 \\
\hline Inventory & 255.8 & 14.4 & 224.6 & 555.4 & 559.5 & 111.5 & 146.0 & 17.6 & 36.7 & 2.6 & 11.5 \\
\hline Net Production & +82.5 & +6.8 & +86.3 & +184.0 & +506.3 & +92.1 & +236.2 & -7.2 & -27.2 & -.3 & -.5 \\
\hline \multicolumn{12}{|l|}{1963} \\
\hline Circulation Change & +50 & +4 & +48 & +167 & +505 & +180 & +520 & +5 & -2 & 0 & -1 \\
\hline Inventory & 284.3 & 15.9 & 241.2 & 540,4 & 546.5 & 111.2 & 132.4 & 14.1 & 20.7 & 2.4 & 11.6 \\
\hline Net Proâuction & +59.9 & +3.1 & +76.3 & +219.8 & +579.8 & +167.8 & +528.1 & +3.5 & $-1: 2$ & -.3 & -.2 \\
\hline
\end{tabular}


TABLE IS (cont.)

\begin{tabular}{|c|c|c|c|c|c|c|c|c|c|c|c|}
\hline$\cdot$ & $\$ 1$ & $\$ 2$ & $\$ 5$ & $\$ 10$ & $\$ 20$ & $\$ 50$ & $\$ 100$ & $\$ 500$ & $\$ 1000$ & $\$ 5000$ & $\$ 10000$ \\
\hline \multicolumn{12}{|l|}{1964} \\
\hline Circulation Change & +110 & +10 & +100 & +276 & +709 & +187 & +544 & +2 & -1 & -1 & 0 \\
\hline Inventory & 294.2 & 15.2 & 270.1 & 592.5 & 621.2 & 99.0 & 140.5 & 13.4 & 21.5 & 2.4 & 12.1 \\
\hline Net Production & +86.7 & +8.6 & +131.4 & +307.4 & +784.1 & +201.4 & +555.9 & -.1 & -2.0 & +.1 & +.9 \\
\hline$\cdots$ & & & & & & & & & & & \\
\hline
\end{tabular}




\section{APPENDIX C}

Availability of Statistics on Currency Denominations:

Selected Countries

A survey of the reports of central banks in selected Western European countries ${ }^{1}$ suggests that their denominational statistics are particularly well suited to studies of long-term currency behavior. Although these statistics are occasionally discontinuous ${ }^{2}$ and are seldom published on anything but an aniual basis, most of them extend far back into the 19th century. In a few cases information on currency denominations is surprisingly good. The Banque Nationale Suisse, for example, has published statistics on the weekly circulation of notes by denomination since 1907. Monthly data on the circulation of Swedish and Norwegian bank notes by denomination has been available since 1960 .

\footnotetext{
IThe survey included a review of the annual reports and (where available) monthly bulletins of the central banks in each of the following countries: Germany, Switzerland, France, Belgium, Italy, the Netherlands, Sweden, Norway, Greece and England. (By implication, it also included other countries such as Luxembourg, which use the notes of those under review.) In all the reports which were surveyed the definition of "currency in circulation" roughly corresponds to that used by the Board of Governors of the Federal Reserve System (excluding holdings by the central bank and national treasury). For a list of the reports see footnote to Table 16.

2That is, certain denominations of currency are replaced by other denominations as banking practices and public habits change.
} 
The results of the survey are outlined in Table $16 .{ }^{3}$ As noted on line 3 of this table, annual statistics on the circulation of notes by denomination are available as early as 1855 for. France, 1864 for the Netherlands, 1866 for Belgium, and 1876 for Germany. The central banks of Switzerland, Italy, Norway and Sweden publish similar statistics as early as 1907, 1933, 1944 and 1951, respectively. The Bank of England did not publish data on the circulation of notes by denomination until 1960, although preliminary evidence suggests that earlier statistics might be available in unpublished form. 4

Since the issuance of coin is generally a function of the national treasury, central banks seldom report denominational statistics on coin. The central bank reports of Germany, France, and Norway do include such information, however.

Each of the reports gives some indication of the amount of currency lost, destroyed, or carried abroad over the previous year, although this is never presented on a denominational basis.

Finally, whenever a change occurs in the denominations of currency issued by the central bank the report usually. gives a description of the change and an indication of the means through which the redundant denominations will be retired.

${ }^{3}$ It cannot be sufficiently emphasized that this survey was limited to a study of central bank reports and did not include an analysis of the publications of national treasuries. Also, there is the possibility that additional statistics on currency denominations are available in unpublished form from the individual banks.

TThe report of the remaining central bank, the Bank of Greece, contains no indication of the denominations of currency circulating in that country. 
TABLE 16

AVATIABILITY OF STAIISTICS ON CURRENCY DENONINATIONS FOR SEIECIED COUITRIES

\begin{tabular}{|c|c|c|c|c|c|c|c|c|c|c|}
\hline $\begin{array}{lllll}\ldots \ldots & \ldots & \ldots & \ldots\end{array}$ & 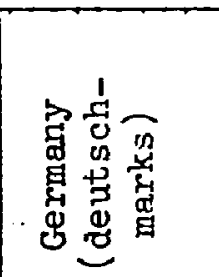 & 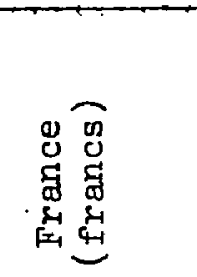 & 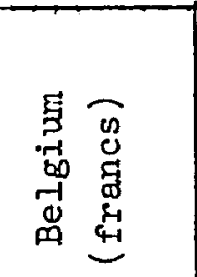 & 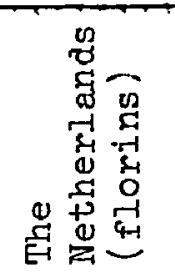 & 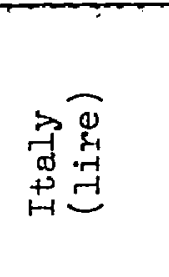 & 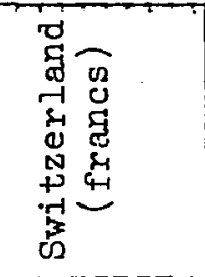 & 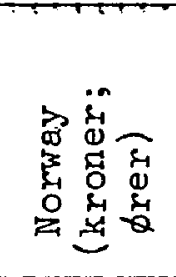 & 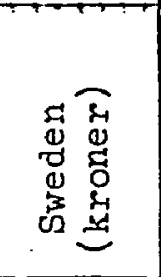 & 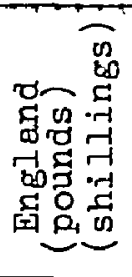 & 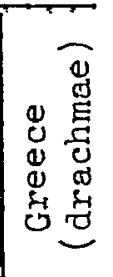 \\
\hline $\begin{array}{l}\text { Denominations of } \\
\text { Notes Published } \\
\text { (current) } \\
\text {. }\end{array}$ & $\begin{array}{l}5,10,20 \\
50,100 \\
500,1000 \\
\text { DM }\end{array}$ & $\begin{array}{l}5,10, \\
50,100 \\
500 \mathrm{FF}\end{array}$ & $\begin{array}{l}20,50 \\
100,500 \\
1000 \\
\quad \mathrm{BF}\end{array}$ & $\begin{array}{l}10,20, \\
25,50, \\
100 \\
1000 \mathrm{f} .\end{array}$ & $\begin{array}{l}50,100 \\
500 \\
1000 \\
\text { Ir }\end{array}$ & $\begin{array}{l}5,10,20, \\
50,100, \\
500 \\
1000 \\
\text { SF }\end{array}$ & $\begin{array}{l}5,10 \\
50,100 \\
500 \\
1000 \\
\mathrm{kr}\end{array}$ & $\begin{array}{l}1,5 \\
10,50 \\
100 \\
1000 \\
10,000 \\
\text {, }\end{array}$ & $\begin{array}{l}10 \mathrm{~s}, \\
1 E \\
5 E \\
10 E\end{array}$ & N.A. \\
\hline $\begin{array}{l}\text { Denominations of } \\
\text { Coin Published } \\
\text { (current) }\end{array}$ & $\begin{array}{l}-.01,-.02 \\
-.05,-.10 \\
-.50,1 .- \\
2 .-, 5 .- \\
\text { DM }\end{array}$ & $\begin{array}{r}-.05 \\
-.10 \\
-.20 \\
-.50 \\
1,3 \mathrm{FF} \\
\end{array}$ & N.A. & N.A. & $N, A$. & N.A. & $\begin{array}{l}1,2,5, \\
10,25 \\
50 \text { фrer }\end{array}$ & N.A. & N.A. & N.A. \\
\hline $\begin{array}{l}\text { Published Annual]y } \\
\text { since: }\end{array}$ & 1876 & 1855 & 1866 & 1864 & 1933 & 1907 & 1944 & 1951 & 1960 & N.A. \\
\hline $\begin{array}{l}\text { Published Monthly } \\
\text {... since: } \ldots\end{array}$ & $\mathrm{N}, \mathrm{A}$, & $\ldots \mathrm{N}, \mathrm{A}$ & N,A. & N.A. & 1966 & $\begin{array}{l}\text { weekly } \\
\text { since } \\
1907\end{array}$ & 1960 & 1960 & N.A. & N.A. \\
\hline
\end{tabular}

SOURCE. Selected issues of the following central bank reports (year following source shows first report surveyed): for Germany (Report of the Deutsche Bundesbank, Frankfort a.M., 1960; Report of the Deutscher Länderbank, 1948; Report of the Deutsche Reichsbank, 1876); France (Compte Rendu des! Operations, Banque de France, 1830); Belgium. (Rapport de l!Anné, Banque Nationale de Belgique, 1852); The Netherlands (Verslag van de Nederlandsche Bank, 1864); Italy (Assemblea Generale Ordinaria dei Partecipanti, Banca d'Italia, 1933); Switzerland (Rapport de la Banque Nationale Suisse, 1909); Norway (Report and Accounts for the Year, Norges Bank, 1960); Sweden (Sveriges Riksbank: Aarsbok, 1960); England (Annual Report, Bank of England, 1960); Greece (Report of the Bank of Greece, 1955).

N.A.: Information not available from central bank reports. 


\section{BIBLIOGRAPHY}

BOOKS AND MONOGRAPHS

Cagan, Philiip. Determinants and Effects of Changes in the Stock of Money, 1875-1960. New York: National Bureau of Economic Research, 1965.

- The Demand for Currency Relative to the Total Money Supply. Occasional Paper 62. New York: National Bureau of Economic Research, 1958.

de Leeuw, Frank. The Demand for Money: Speed of Adjustment, Interest Rates, and Wealth (Staff Economic Studies). U.S., Board of Governors of the Federal Reserve System, 1965.

Feige, Edgar. The Demand for Liquid Assets: A Temporal Cross-Section Analysis. Englewood Cliffs, N.J.: Prentice-Hall, 1964.

Friedman, Milton (ed.). Studies in the Quantity Theory of Money. Chicago: University of Chicago Press, 1956. and Schwartz, Anna. A Monetary History of the United States. New York: National Bureau of Economic Research, 1963.

Kàhn, Harry. Business and Professional Income Under the Personal Income Tax. New York: National Bureau of Economic Research, 1964.

Kaufman, George. The Demand for Currency (Staff Economic Studies). U.S., Board of Governors of the Federal Reserve System, 1966.

Schwartz, Anna and Oliver, Elma. Currency Held by the Public, the Banks, and the Treasury Monthly, December 1917 - December 1944. Technical Paper 4. New York: National Bureau of Economic Research, 1947.

\section{PERIODICAIS}

Baumol, William. "The Transactions Demand for Cash: An Inventory Theoretic Approach," Quarterly Journal of Economics, IXVI (1952), 545-56.

Bronfenbrenner, M. and Mayer, T. "Liquidity Functions in the American Economy," Econometrica, XXVIII (1960), 810-34. 
Klein, John J. "Price-Level and Money-Denomination Movements," Journal of Political Economy, IXVII (1960), 369-78.

McDonald, Stephen. "Some Factors Affecting the Increased Relative Use of Currency Since 1939," Journal of Finance, XI (1956), 313-27.

Meltzer, Allan. "The Demand for Money: The Evidence from Time Series," Journal of Political Economy, IXXI (1963), 219-46.

Teigen, Ronald. "Demand and Supply Functions for Money in the United States: Some Structural Estimates," Econometrica, XXXII (1964), 476-509.

Tobin, James. "Liquidity Preference and Monetary Policy," Review of Economic Statistics, XXIX (1947), 124-31.

- "The Interest Elasticity of Transactions Demand for Cash," Review of Economics and Statistics, XXXVIII (1956), 241-47.

GOVERNMENT PUBLICATIONS

Banca d'Italia. Assemblea Generale Ordinaria dei Participanti. 1933-66.

Bank of England. Annual Reports. 1960-66.

Bank of Greece. Annual Reports. 1955-66.

Banque de France. Compte Rendu des Opérations. 1830-1966.

Banque Nationale de Belgique. Rapport de l'Anné. 1852-1966.

Banque Nationale Suisse. Rapport. 1909-66.

Deutsche Bundesbank. Annual Reports. 1960-66.

Nederlandsche Bank. Verslag van de Nederlandsche Bank. 1864-1966.

Norges Bank. Report and Accounts. 1960-66.

Sveriges Riksbank. Aarsbok. 1960-66.

U.S. Board of Governors of the Federal Reserve System. Banking and Monetary Statistics. Washington: National Capital Press, 1943. - Federal Reserve Bulletin. (February issues, 1932-66). 
U.S. Bureau of the Census. Historical Statistics: Colonial Times to 1957 (and Supplement). Washington, 1960.

- Statistical Abstract. Washington, 1966.

U.S. Federal Deposit Insurance Corporation. Annual Reports. 1961-66.

U.S. Department of the Treasury, Secretary of the Treasury. Annual Reports. 1914-66. 